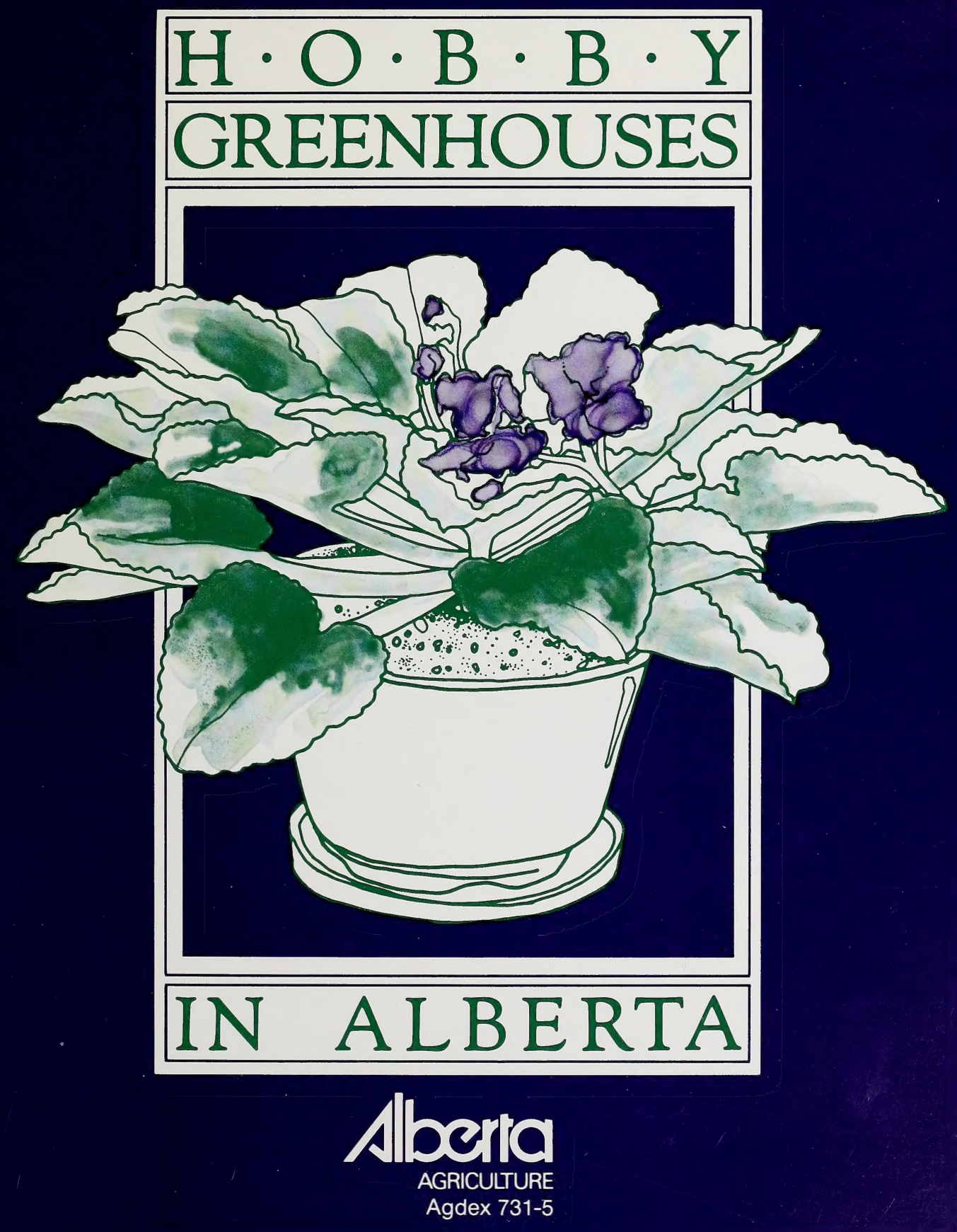


Copies of this publication may be obtained from:

Print Media Branch

Alberta Agriculture

7000 - 113 Street

Edmonton, Alberta, T6H 5T6

OR

Alberta Agriculture's district offices

Revised 198909 10M 


\section{hobby greenhouses in alberta}

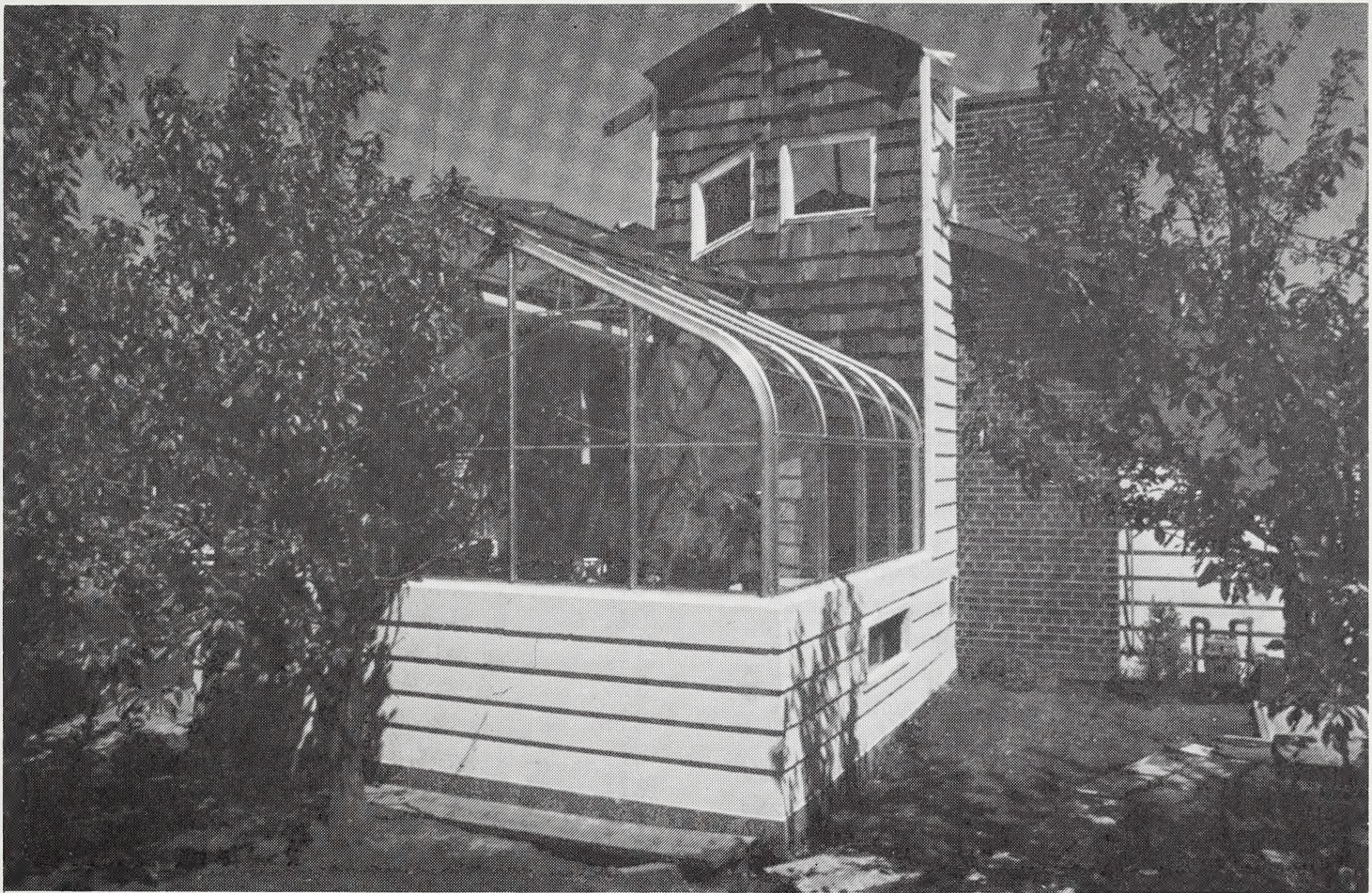

Mirza Mohyuddin

Greenhouse Specialist

Alberta Tree Nursery and Horticulture Centre,

Edmonton

Dennis Darby and John Chang

Farm Structure Engineers

Engineering and Resource Branch

Betty Vladicka

Extension Horticulturist

Alberta Tree Nursery and Horticulture Centre,

Edmonton 
Digitized by the Internet Archive in 2015

https://archive.org/details/hobbygreenhouses00mohy 


\section{Table of Contents}

INTRODUCTION $\ldots \ldots \ldots \ldots \ldots \ldots \ldots \ldots \ldots \ldots$. 1

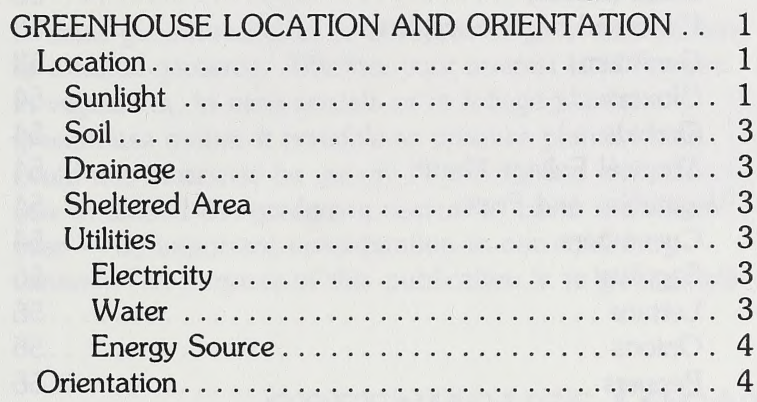

\section{GREENHOUSE DESIGN, CONSTRUCTION}

AND MAINTENANCE .............. 5

Design ........................ 5

Types of Greenhouse Structures .......... 5

Prefabricated or Homemade

Cost Considerations ............... 8

Size of Greenhouse . . . . . . . . . . . . . . . . 8

Solar-heated Greenhouses . . . . . . . . . . . . . . . . 9

Typical Uses of the Solar Greenhouse . . . . . . . . 10

The Sun Space . . . . . . . . . . . . . . . . . . . . . 10

Extended Living Space . . . . . . . . . . . . . 10

Season Extender . . . . . . . . . . . . . . . . 10

Year Round Plant Production . . . . . . . . . . . . . 10

Solar Heating: Passive, Active, Hybrid . . . . . . . . . 10

The Collector ...................11

Phase Change Materials ................12

Storage Location . . . . . . . . . . . . . . . . . . . . 13

Heat Transfer . . . . . . . . . . . . . . . . . . . . 13

Controls .........................13

Solid North Wall . . . . . . . . . . . . . . . . . . . . 14

Double Glazing . . . . . . . . . . . . . . . . . 14

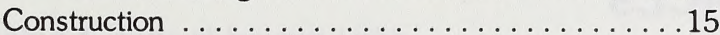

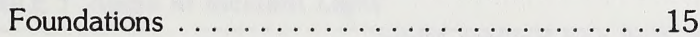

General . . . . . . . . . . . . . . . . . . . . . . . 15

Treated-wood Foundation . . . . . . . . . . . . . . . 15

Concrete Foundation . . . . . . . . . . . . . . . . . 15

Framework . . . . . . . . . . . . . . . . . . . . 15

Wood ........................ 15

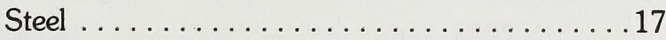

Aluminum Alloy ................... 17

Greenhouse Coverings . . . . . . . . . . . . . . 17

Glass . . . . . . . . . . . . . . . . . . . . . . 17

Plastics . . . . . . . . . . . . . . . . . . . 18

Fibreglass . . . . . . . . . . . . . . . 18

Polyethylene . . . . . . . . . . . . . . 18

Glazing Management . . . . . . . . . . . . 22

Installing Glass . . . . . . . . . . . . 22
Installing Fibreglass Reinforced Panels . . . . . . . 22

Installing Single and Double Layer Polyethylene . . . 23

The Greenhouse Interior . . . . . . . . . . . . . . . . 24

Benches . . . . . . . . . . . . . . . . . . . 24

Beds . . . . . . . . . . . . . . . . . . . . . 26

Shelves ... . . . . . . . . . . . . . . . . . . . . . 26

Storage for Supplies . . . . . . . . . . . . . . . 26

Flooring ......................26

Maintenance. . . . . . . . . . . . . . . . .26

Maintenance Checklist .................26

ENVIRONMENTAL CONTROL . . . . . . . . . . 27

Heating . . . . . . . . . . . . . . . . 27

Hot Water Heating . . . . . . . . . . . . . . 27

Gas and Oil Space Heaters . . . . . . . . . . . . 28

Kerosene Heaters . . . . . . . . . . . . . . . . . . 28

Electric Heaters . . . . . . . . . . . . . . . . . 28

Solar Heat . . . . . . . . . . . . . . . . . . . . . 28

Heating Attached Greenhouses . . . . . . . . . 28

Energy Conservation . . . . . . . . . . . . . . . .29

Movable Blankets or Shutters . . . . . . . . . . . . 30

Pop-in Shutters. . . . . . . . . . . . . . . . . . . 30

Track-supported Blanket . . . . . . . . . . . . . .31

Blanket Insulation . . . . . . . . . . . . . . . . . 32

Roll-up Blankets . . . . . . . . . . . . . . . 33

Exterior Insulation . . . . . . . . . . . . . . . 33

Vapor Barriers . . . . . . . . . . . . . . . . 33

Other Energy Conserving Measures . . . . . . . . . . . 33

Reduce Air Leaks . . . . . . . . . . . . . . . . . . 33

Efficient Heating Equipment . . . . . . . . . . . . . 33

Water . . . . . . . . . . . . . . . . . . . . . . . 33

Winter Shut Down . . . . . . . . . . . . . . . . . 33

Emergency Heating . . . . . . . . . . . . . . . . . . 34

Ventilation ... . . . . . . . . . . . . . . . . . .34

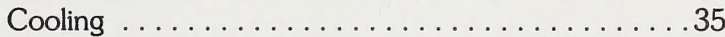

Humidity . . . . . . . . . . . . . . . . . . 36

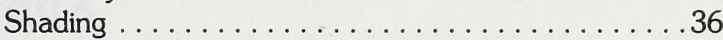

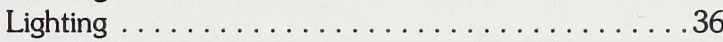

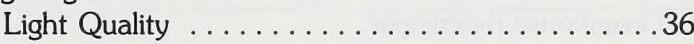

Light Intensity. . . . . . . . . . . . . . . 37

Light Duration . . . . . . . . . . . . . 37

Artificial Lights . . . . . . . . . . . . . . . . . 38

Incandescent Lamps . . . . . . . . . . . . . . 40

Fluorescent Lamps . . . . . . . . . . . . . . . 40

Water Systems ..................... . 40

Mist Nozzles. . . . . . . . . . . . . . . . . . .40

Spaghetti Tubes ...................40

Capillary Mat . . . . . . . . . . . . . . .41

PLANTS AND THEIR REQUIREMENTS $\ldots \ldots \ldots .41$

Growth Media . . . . . . . . . . . . . . . . . . .41

Soil . . . . . . . . . . . . . . . . . . . .41 
Soil Mixes... . . . . . . . . . . . . . . . . . .42

Hydroponics . . . . . . . . . . . . . . . . . .42

Fertilizing . . . . . . . . . . . . . . .44

Types of Fertilizer . . . . . . . . . . . 44

Quantity and Timing of Fertilizer Applications . . . 44

Water ... . . . . . . . . . . . . . . . . . . . . 45

Water Quality . . . . . . . . . . . . . . . . . .45

Special Management Practices . . . . . . . . . . . 45

Acidifying Water Supplies. . . . . . . . . . . . . .45

Phosphoric Acid . . . . . . . . . . . . . 46

Nitric Acid. . . . . . . . . . . . . . . . . . 46

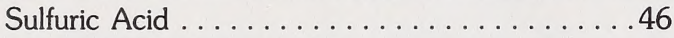

Hydrochloric Acid . . . . . . . . . . . . . 46

Chlorination ...................46

Fluoridation ................46

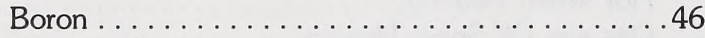

Sodium . . . . . . . . . . . . . . . . . .47

Pollutants . . . . . . . . . . . . . . .47

Water Quantity. . . . . . . . . . . . . . . . . . 47

PEST MANAGEMENT . . . . . . . . . . . . . 47

Pesticide Usage . . . . . . . . . . . . . . . . 47

Diseases. . . . . . . . . . . . . . . . . . . . .48

Fungal Disease ..................48

Damping Off . . . . . . . . . . . . . . . 48

Botrytis . . . . . . . . . . . . . . . . . . . .48

Powdery Mildew . . . . . . . . . . . . . . . . . . . 48

Viral Disease ... . . . . . . . . . . . . . . . . . 49

Bacterial Disease . . . . . . . . . . . . . . . . . . . 49

Insects . . . . . . . . . . . . . . . . . . . . . . . .49

Identification . . . . . . . . . . . . . . . . 499

Control . . . . . . . . . . . . . . . . . . . . . . 499

Biological Control . . . . . . . . . . . . . . . . . . .49

Mechanical Control . . . . . . . . . . . . . . . . . . 499

Chemical Control ...................449
GREENHOUSE PLANTS . . . . . . . . . . . . . . . 52

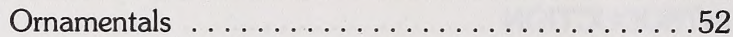

Annual Bedding Plants . . . . . . . . . . . . . . . . 52

Bulbs (forced) . . . . . . . . . . . . . . . . . . . . 52

Cacti and other Succulents. . . . . . . . . . . . 53

Geraniums . . . . . . . . . . . . . . 53

Gloxinia . . . . . . . . . . . . . . . . . . . 54

Orchids . . . . . . . . . . . . . . . . . . . . 54

Tropical Foliage Plants . . . . . . . . . . . . . . 54

Vegetables and Fruits . . . . . . . . . . . . . . . 54

Cucumbers ....................... . . 54

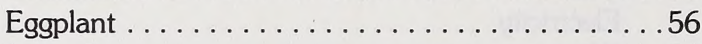

Lettuce . . . . . . . . . . . . . . . . . 56

Onions . . . . . . . . . . . . . . . . .56

Peppers ....................56

Radishes ......................56

Strawberries ..................56

Tomatoes . . . . . . . . . . . . . . . 56

Propagation from Cuttings . . . . . . . . . . . . . 557

\section{APPENDICES}

1. Greenhouse References . . . . . . . . . . . . . . 58

2. Greenhouse Plans . . . . . . . . . . . . . . . 60 60

3. Some Canadian Suppliers of Greenhouse Materials . . . . . . . . . . . . . . . . .661

4. Ideas for Solar-Heated Greenhouses . . . . . . . . . . 62
5. Soil and Soilless Mixes . . . . . . . . . . . . 63

6. Hydroponic Nutrient Solution . . . . . . . . . . . 64

7. Small Pipe Frame Greenhouse and

Small Wood Frame Greenhouse. 


\section{HOBBY GREENHOUSES IN ALBERTA}

\section{INTRODUCTION}

A small greenhouse can be a source of great satisfaction to a home gardener. Whether your interest is in flowers, in vegetables, in ornamentals or in foliage plants, a greenhouse makes it possible to produce plants which could not otherwise be grown. A greenhouse also allows you to extend the gardening season to cover the whole year - an important consideration in our cold, long winters. The purpose of this publication is to give simple basic instructions regarding the building, heating and managing of small greenhouses suitable for the amateur. The information contained here is basic and is as detailed as space will allow. There are also many good books available on small greenhouses that can be used to supplement the information in this publication (see Appendix 1).

\section{GREENHOUSE LOCATION AND ORIENTATION}

A number of factors must be considered when deciding where to locate a greenhouse: light levels, soil conditions, drainage, degree of shelter, availability of utilities and ease of access from your home.

\section{Location}

\section{Sunlight}

Locate your greenhouse to obtain the most light possible. If the structure is to be attached to an existing building, it should be located on a southern exposure. If the structure is to be free standing, do not build near large trees or other obstructions which will shade the building. If you plan to operate your greenhouse year round, primary consideration should be given to obtaining maximum sunlight exposure during midwinter when the sun is lowest in the sky.

Bright light conditions, such as those provided by a southern exposure, will allow you to grow a wide variety of greenhouse crops. The choice can range from the high light-requiring crops such as vegetables and cut flowers to those that require some degree of shade such as foliage plants. It is feasible to locate a greenhouse in an exposure that is not southern; however, you will be limited to plants that can tolerate lower light levels unless you install supplementary lighting.

It is desirable and relatively easy to determine how far to locate a greenhouse from an existing structure to prevent shading. One easy method is to stake out the path of the shadow cast by nearby buildings or other tall structures at all times of the day and seasons, and then locate the greenhouse away from the path of the shadow.

Another method is to determine the angle of the sun, which is called the angle of incidence. Table 1 gives the sun angle for various locations at different times of the year. Next, using graph paper, draw to scale the proposed location of your greenhouse (see figure 2) and use the scale to determine the proper location.

\section{TABLE 1. Angle of Incident Light}

Date

December 21

Nov. or Jan. 21

Oct. or Feb. 21

Sept. or Mar. 21

Aug. or Apr. 21

July or May 21

June 21
Angle of

Declination
Location (degree of latitude) $52^{\circ}$ $54^{\circ}$ $56^{\circ}$ Angle of incidence

$\begin{array}{rr}23.5^{\circ} & 16.5^{\circ} \\ 19.5^{\circ} & 20.5^{\circ} \\ 11.0^{\circ} & 39.0^{\circ} \\ 0.0^{\circ} & 40.0^{\circ} \\ 12.0^{\circ} & 52.0^{\circ} \\ 20.0^{\circ} & 60.0^{\circ} \\ 23.5^{\circ} & 63.5^{\circ}\end{array}$

$14.5^{\circ}$
$18.5^{\circ}$
$37.0^{\circ}$
$38.0^{\circ}$
$50.0^{\circ}$
$58.0^{\circ}$
$61.5^{\circ}$

$14.5^{\circ}$

$18.5^{\circ}$

$38.0^{\circ}$

$50.0^{\circ}$

$58.0^{\circ}$

$\begin{array}{ll}12.5^{\circ} & 10.5^{\circ} \\ 16.5^{\circ} & 14.5^{\circ} \\ 35.0^{\circ} & 33.0^{\circ} \\ 36.0^{\circ} & 34.0^{\circ} \\ 38.0^{\circ} & 36.0^{\circ} \\ 56.0^{\circ} & 54.0^{\circ} \\ 59.5^{\circ} & 57.5^{\circ}\end{array}$

Angle of incident light $=90^{\circ}$ (latitude + angle of declination) on December 21

Angle of incident light $=90^{\circ}$ (latitude - angle of declination) on June 21 


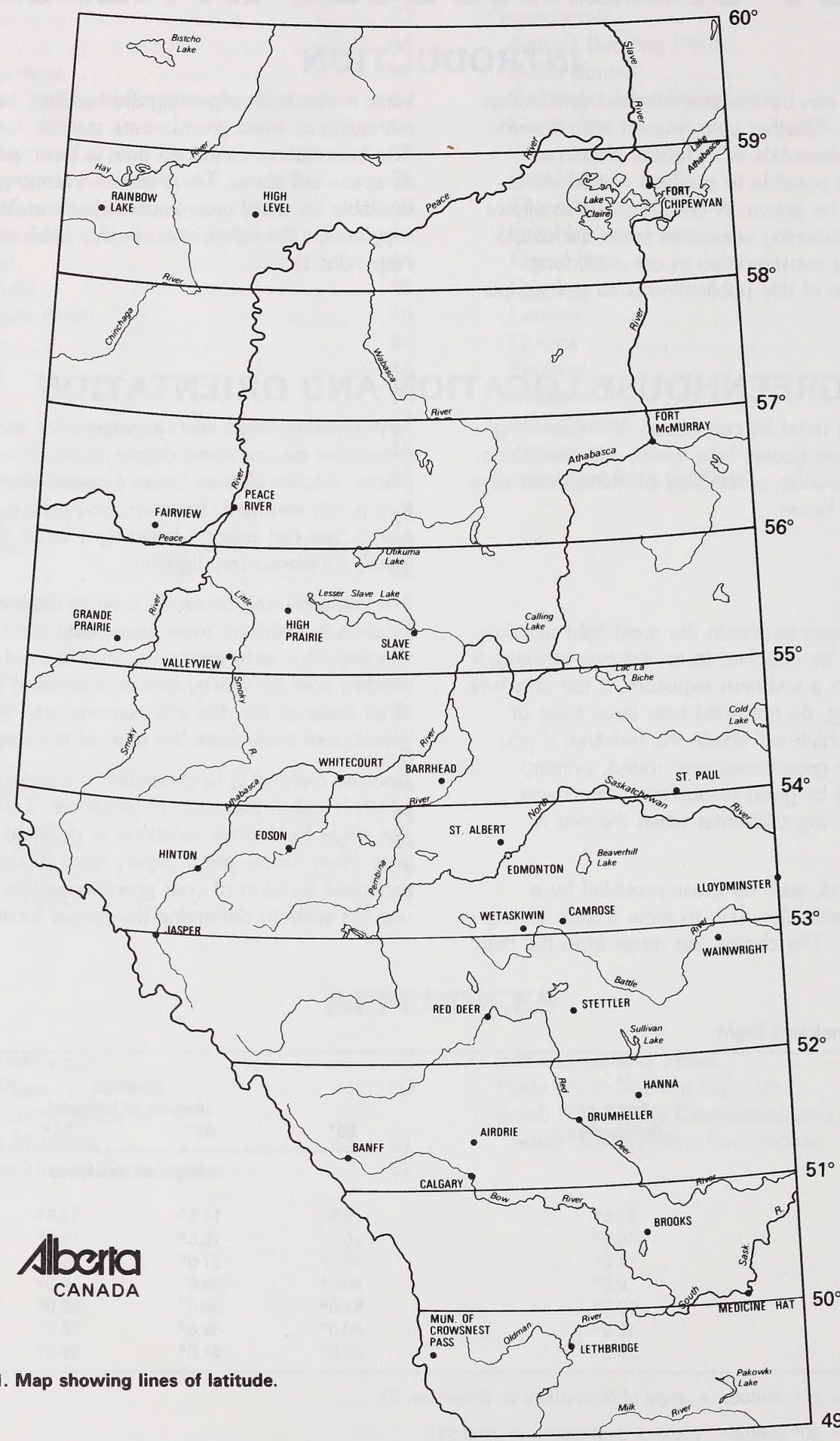

Figure 1. Map showing lines of latitude. 


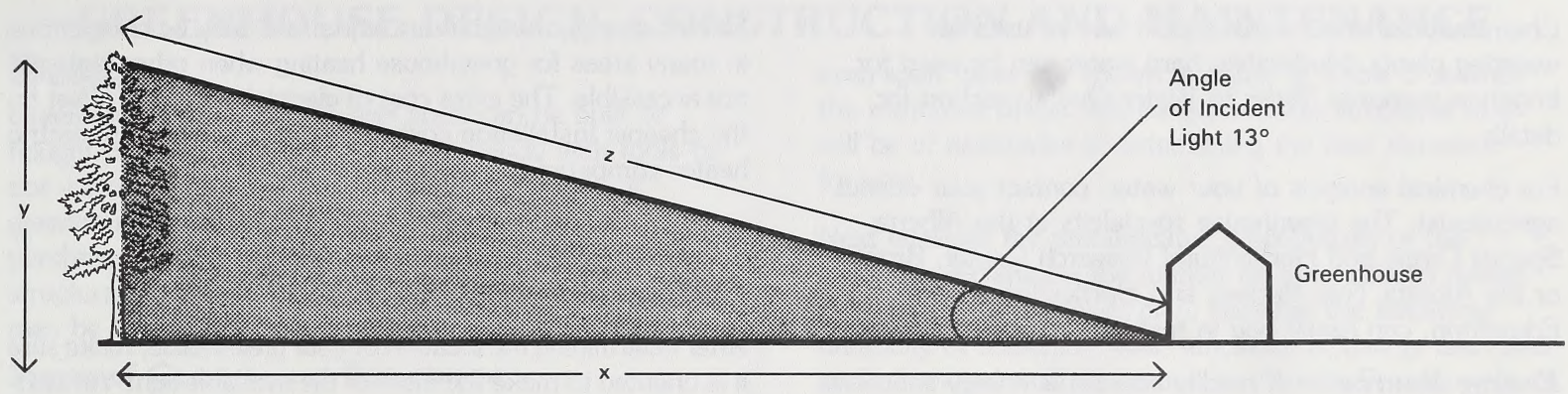

Figure 2. Greenhouse location

\section{Soil}

Soil conditions are important only if plants are to be grown directly in the soil covered by the greenhouse. If this is the case, select a site with deep, well-drained fertile soil. A sandy loam soil is preferable. Although organic matter and artificial conditioners can be added, you will have fewer problems if the naturally occurring soil is good. Make sure the soil has not been previously sprayed with residual herbicides (e.g., Picloram) that could harm your crop. If there is doubt about the presence of chemicals, grow plants such as tomatoes, cucumbers and radishes and observe their growth for two weeks.

Abnormal growth patterns would indicate the presence of herbicides.

When a good soil is not available, consider using benches or pots with artificial media, such as peat or vermiculite, or use a different hydroponic method.

\section{Drainage}

A well-drained site is necessary for foundation construction and, if growing plants in ground beds, for reducing problems with salt build-up and insufficient soil aeration. If necessary, tile drain the area enclosed by the greenhouse. Ground beds should be nearly level so that water will not accumulate in any one area.

\section{Sheltered Area}

As long as sunlight is not reduced, small greenhouses should be located in a sheltered area to reduce windrelated heat losses. For example, a wind barrier north and northwest of the greenhouse may materially reduce heating loss, yet it would have little effect on the light received. A general rule of thumb is that a windbreak will provide protection for a distance up to ten times its height. Making sure that there are no cold air flows over or by your greenhouse can also reduce the heating bill. Cold air runs downhill like water and can be dammed by a solid structure - keep the greenhouse at least $4 \mathrm{~m}$ from such a solid barrier.

\section{Utilities}

A greenhouse requires a number of utilities, notably electricity, water and an energy source for heat.

Electricity - plan on running a permanent electrical wire to the greenhouse (usually underground) from an adjoining building's service panel. Be sure that the line and the service breaker are adequately sized for the load. For a small hobbysize house, connect loads of up to 1-2 kilowatts are not unusual for ventilation alone. If supplemental light or if electric heat is used, the electric load will increase significantly. Normally electric power companies will willingly supply the necessary service.

Water - It is one of the most important compounds for growing a crop. Water serves as a medium in which chemical processes such as ion uptake and photosynthesis take place and acts as a coolant for both the plant and its environment through the transpiration process. It is very important to consider the quantity and quality of your water supply before building a greenhouse.

Quantity - Water requirements for a crop can vary between 0.1 and $10 \mathrm{~L}$ of water per square metre of greenhouse per day. This varies according to plant species, plant size, relative humidity, solar radiation, heating and ventilation. For hobby greenhouses, the ordinary domestic water supply should be adequate.

Quality - To determine the quality of the water, a chemical analysis must be undertaken to reveal the alkalinity, hardness, $\mathrm{pH}$, electrical conductivity and presence of chemicals such as sodium, calcium, magnesium, chlorides, sulfates, bicarbonates, nitrate, nitrites, iron and boron.

Water quality is classified as poor when the sodium content is greater than 100 parts per million. The higher the level of sodium, the greater the problems will be. If the water sodium level is between $100-200$ parts per million, it can be managed for plant growth, but for levels above that an alternate source of water is needed. 
Chemically softened water should not be used for watering plants. Moderately hard water can be used for irrigation purposes. Refer to Water Quality section for details.

For chemical analysis of your water, contact your district agriculturist. The greenhouse specialists at the Alberta Special Crops and Horticultural Research Center, Brooks or the Alberta Tree Nursery and Horticulture Centre, Edmonton, can assist you in making recommendations.

Energy Source - A readily accessible energy source is very important in locating a greenhouse. Natural gas is widely used in Alberta because of its relative cheapness, low maintenance and clean performance. Propane gas, fuel oil, coal and wood are alternative sources of fuel and can be transported to greenhouse locations that are not close to gas lines.
Electric energy, though more expensive, may be competitive in many areas for greenhouse heating when other fuels are not accessible. The extra cost of electricity is often offset by the cheaper installation cost or purchase price of an electric heater compared to gas or oil heaters.

\section{Orientation}

After determining the location of your greenhouse, make sure it is oriented to make the most of the available light. An eastwest orientation (i.e. the ridge of the house running east and west) is preferable in the winter for Alberta's latitudes. At other times of the year for Alberta, a north-south orientation of the ridge is preferable. However, since light is most critical during mid-winter, the east-west orientation for single-width houses should be used (see figure 3 for example).
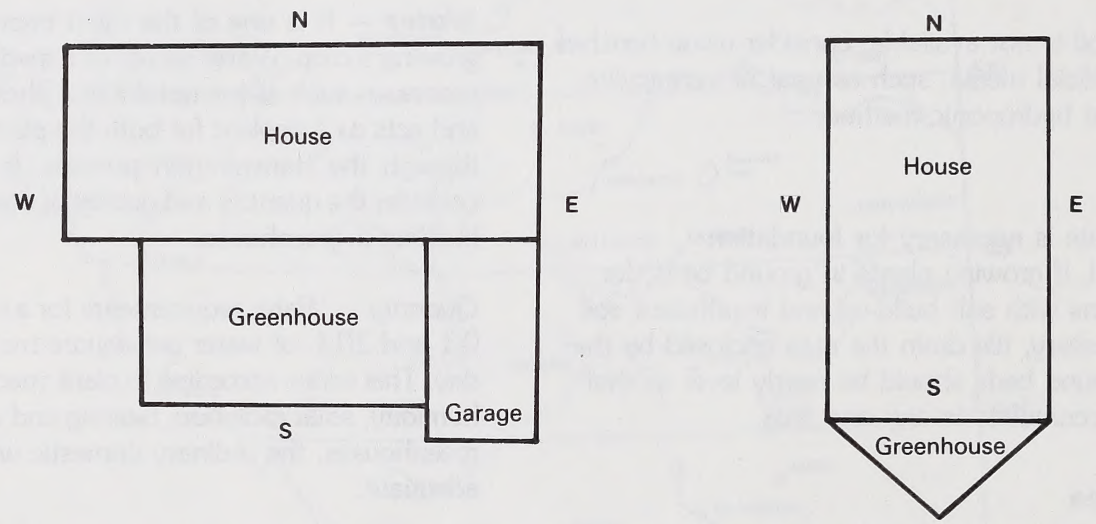

Figure 3. Greenhouse orientation 


\section{GREENHOUSE DESIGN, CONSTRUCTION AND MAINTENANCE}

\section{Design}

Greenhouses of all shapes and sizes can be built or bought prefabricated. If you are not handy with tools or not willing to take the time to study the details of greenhouse construction, you are best advised to purchase a prefabricated model. However, if you have a structural problem specific to your site, custom building may be the only answer.

\section{Types of Greenhouse Structures}

First, consider the types of structures available and decide on one that best suits your needs. Greenhouses can be roughly classified as (a) lean-to's, which are essentially half a box attached to the wall of a building; and (b) even spans, which are complete boxes either attached at one end of a building or left free-standing. Popular lean-to and even-span types are shown in figure 4 . Table 2 outlines the attributes of the various greenhouse structures and will be of assistance in determining the best structure for you.

Next evaluate the prefabricated greenhouses or the greenhouse plans on the market for your chosen design. In evaluating a model or plan, consider the following: durability of materials, cost, efficiency of energy use (solar and otherwise) and adaptation to climate. For example, is the roof sloped enough to allow snow to slide off? (the pitch [the rise:run] should be 1:2). Is the door wide enough to accommodate a wheelbarrow? Is the pitch high enough to hang baskets if desired? Are the side walls high enough to allow the growth of tall plants, such as tomatoes, at the side of the greenhouse if desired?

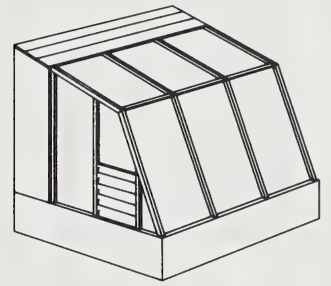

Attached

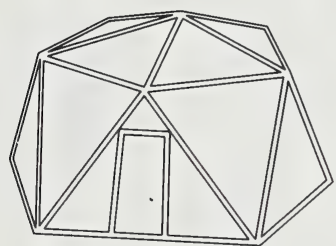

Tri-penta

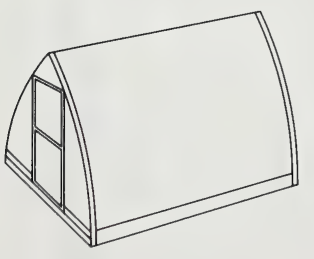

Gothic Arch

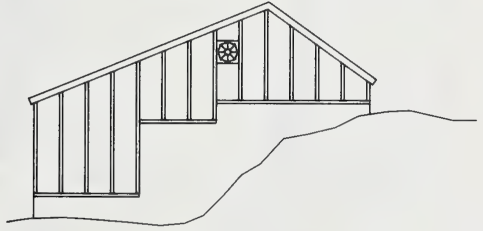

Semi-pit

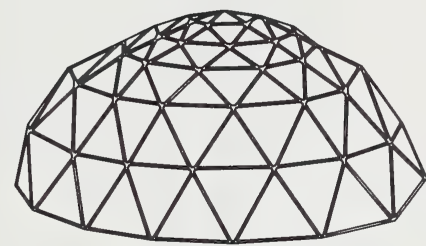

Dome

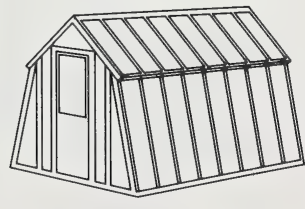

Slant-leg

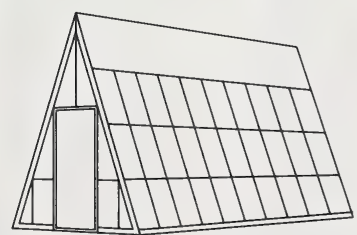

A-frame

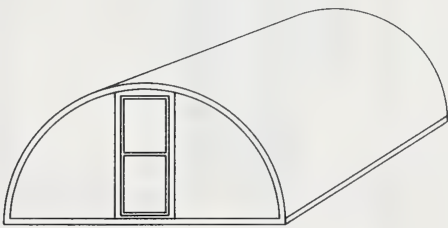

Quonset

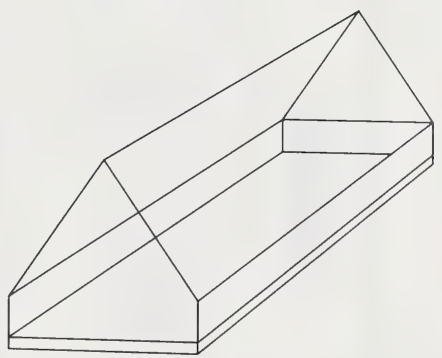

Brace Research Institute

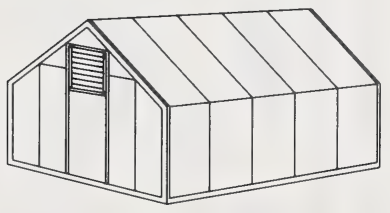

Gable roof

Figure 4. Common types of greenhouse structures 


\begin{tabular}{|c|c|c|c|c|c|}
\hline 点 & 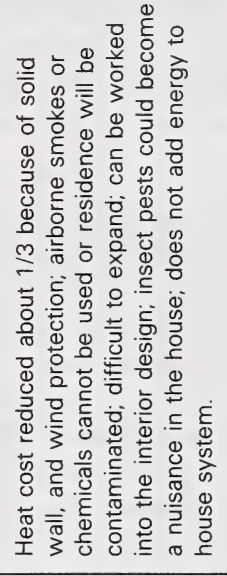 & 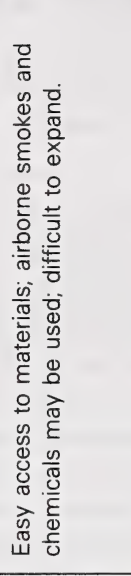 & 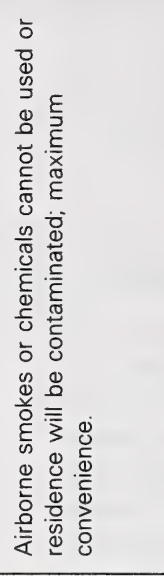 & 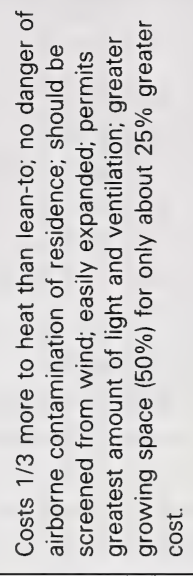 & 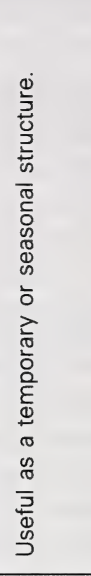 \\
\hline $\begin{array}{l}\text { 巴ّ } \\
\underline{E} \\
\underline{E}\end{array}$ & 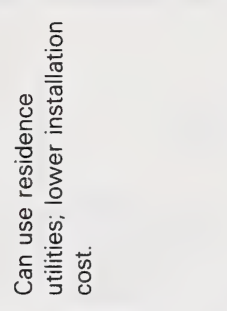 & 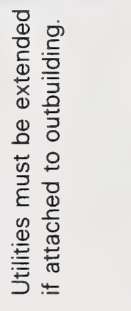 & 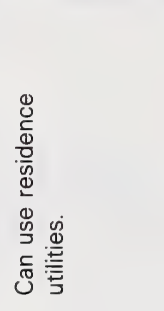 & 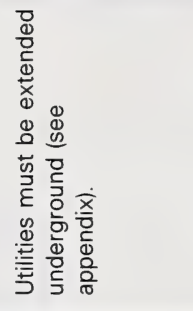 & 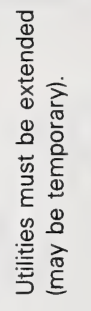 \\
\hline 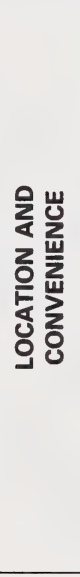 & 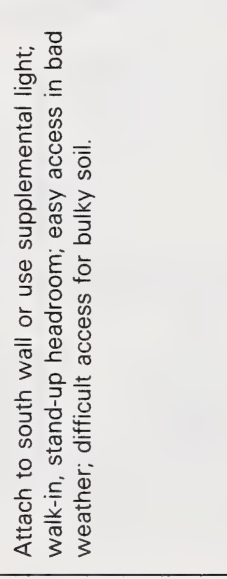 & 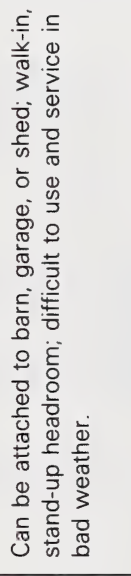 & 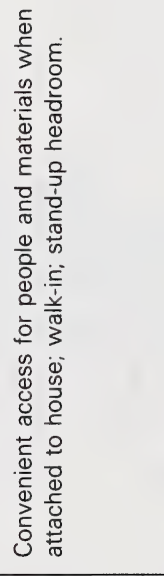 & 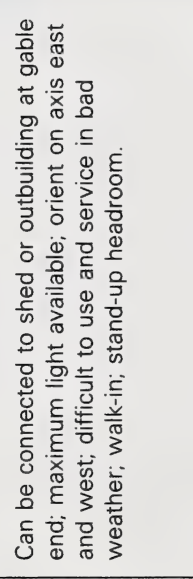 & 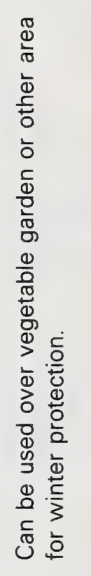 \\
\hline 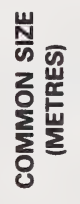 & 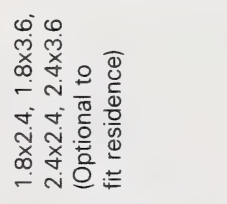 & $\begin{array}{l}0 \\
0 \\
0 \\
\pi \\
0 \\
0 \\
0 \\
0 \\
\stackrel{0}{0} \\
\sim\end{array}$ & 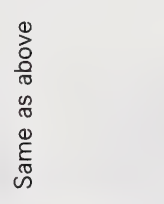 & 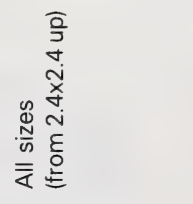 & $\begin{array}{l}\frac{\mathscr{N}}{\omega} \\
\frac{N}{\omega} \\
\bar{\alpha}\end{array}$ \\
\hline 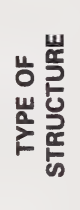 & 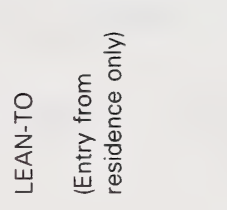 & 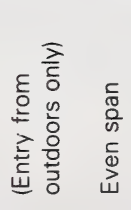 & 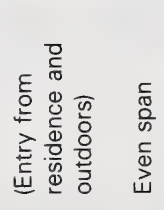 & 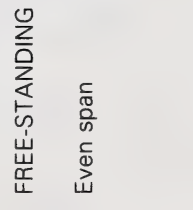 & 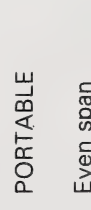 \\
\hline
\end{tabular}




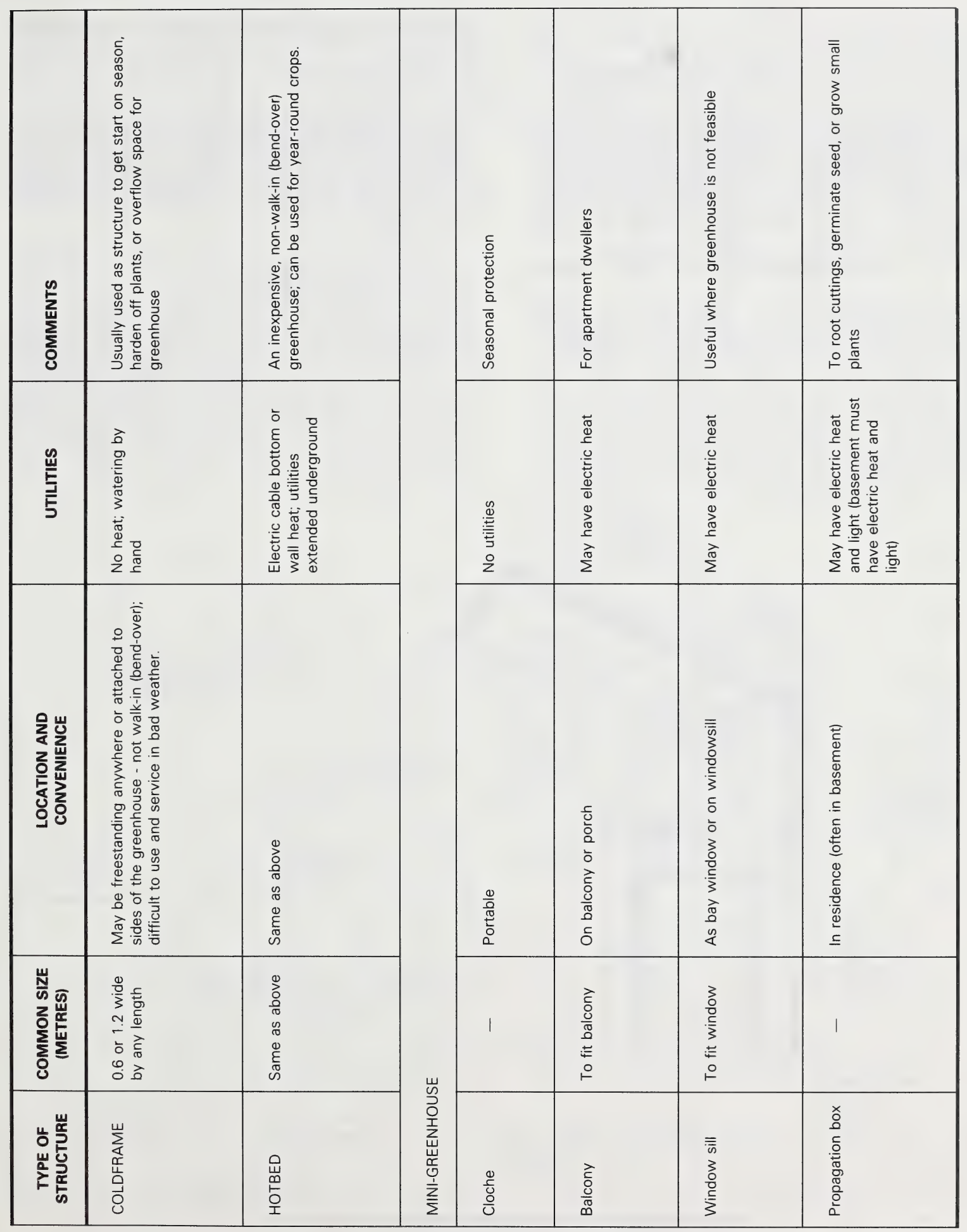




\section{Prefabricated or Homemade - Cost Considerations}

Prefabricated models can range from the traditional (least expensive) to the avant-garde (very expensive). They can be readily purchased from department stores, building supply stores and greenhouse construction firms. Costs of prefabricated greenhouses change frequently because of the fluctuating cost of plastics and glass. Check with the various suppliers to determine the style, features and cost that suit your needs. Quoted prices usually do not include the cost of the foundation, sidewalks, heating and ventilation systems and furnishings.

If you decide to build your own greenhouse, the cost will be less than that of a prefabricated model of the same size. Owing to the many factors involved, it is difficult to estimate cost more precisely.

If you do wish to build your own greenhouse, make sure you work from a good plan or your expense will be greatly increased if you make any mistakes. Appendix 2 contains a list of sources of greenhouse plans. Appendix 7 includes plans for a small wood frame greenhouse and a small pipe frame greenhouse.

If your site poses a special construction problem so that use of prefabricated models or standard greenhouse plans is not possible, there are several larger greenhouse construction firms that can provide stock parts for assembly to fit any special requirement (see Appendix 3).

\section{Size of Greenhouse}

Usually available space and cost, more than need or desire, dictate greenhouse size. All too often this problem leads to the purchase of a flimsy, tiny box that never seems to function properly as a greenhouse. Temperatures fluctuate rapidly in a small greenhouse and heat losses can be almost as high as in a larger greenhouse. A $2 \times 2 \mathrm{~m}$ greenhouse might better be replaced by a $1 \times 2 \mathrm{~m}$ hotbed at a quarter of the price and a tenth of the fuel cost.

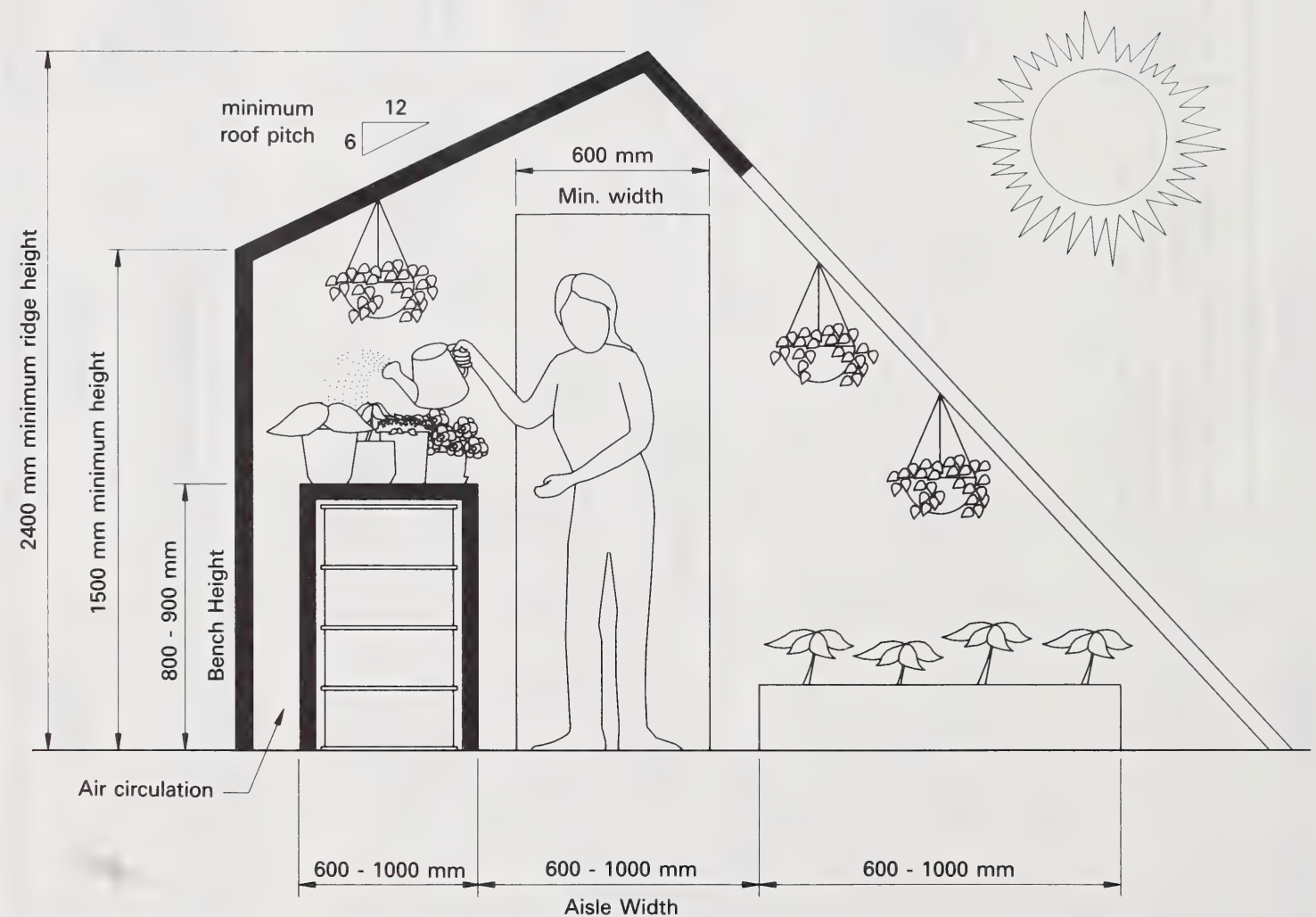

Figure 5. Suggested minimum dimensions for a greenhouse 
When choosing a size, ask yourself how you will use the greenhouse. Are you really an avid gardener who can use the space a greenhouse offers? Can you spend the time needed to maintain it? If you are an avid gardener, select a size somewhat larger than you think you will need. If you are only starting a few seedlings for the summer garden, perhaps a hotbed is a better choice. Remember that the cost of heat, plants, fertilizer and time will soon exceed the initial cost of the greenhouse itself.

The length of a greenhouse depends on available space and money, but $3 \mathrm{~m}$ is the minimum for a freestanding house. Attached greenhouses are sometimes smaller. Small greenhouses are often proportioned so that length does not exceed twice the width. If you are building the greenhouse primarily as a sunspace or heat collector, a long narrow space is generally desirable. This gives a large solar collector area to floor area ratio.

Small greenhouses often do not have enough headroom and are hard to work in. Taller houses heat and ventilate more uniformly, so they require no more or little extra heat than the shorter house. The eave height of gable roof houses should be at least $1.6 \mathrm{~m}$ and ridge heights at least 2.5 $\mathrm{m}$. Doors should be $60 \times 182 \mathrm{~cm}$ or larger. Standard doors are $80 \mathrm{~cm}$ or $90 \mathrm{~cm}$ wide and $198 \mathrm{~cm}$ high.

Figure 5 shows typical widths for aisles and benches. Add at least $15 \mathrm{~cm}$ to each side for air circulation around solid benches or heat storage devices. Minimum outside width for a greenhouse with two side benches and a centre aisle is $2 \mathrm{~m}$. Two and half metres is better.

\section{Solar-heated Greenhouses}

All greenhouses are "solar" in the sense that they trap energy from the sun, utilizing part of it to grow plants and part of it to heat the air and objects inside the greenhouse.

The greenhouse materials-glass, fibreglass or plastic-allow short wave visible radiation to enter the structure. Inside, light is absorbed by plants and other objects. It is later re-emitted as visible radiation of a longer wavelength (infra-red), a large portion of which is low-temperature thermal radiation or heat.

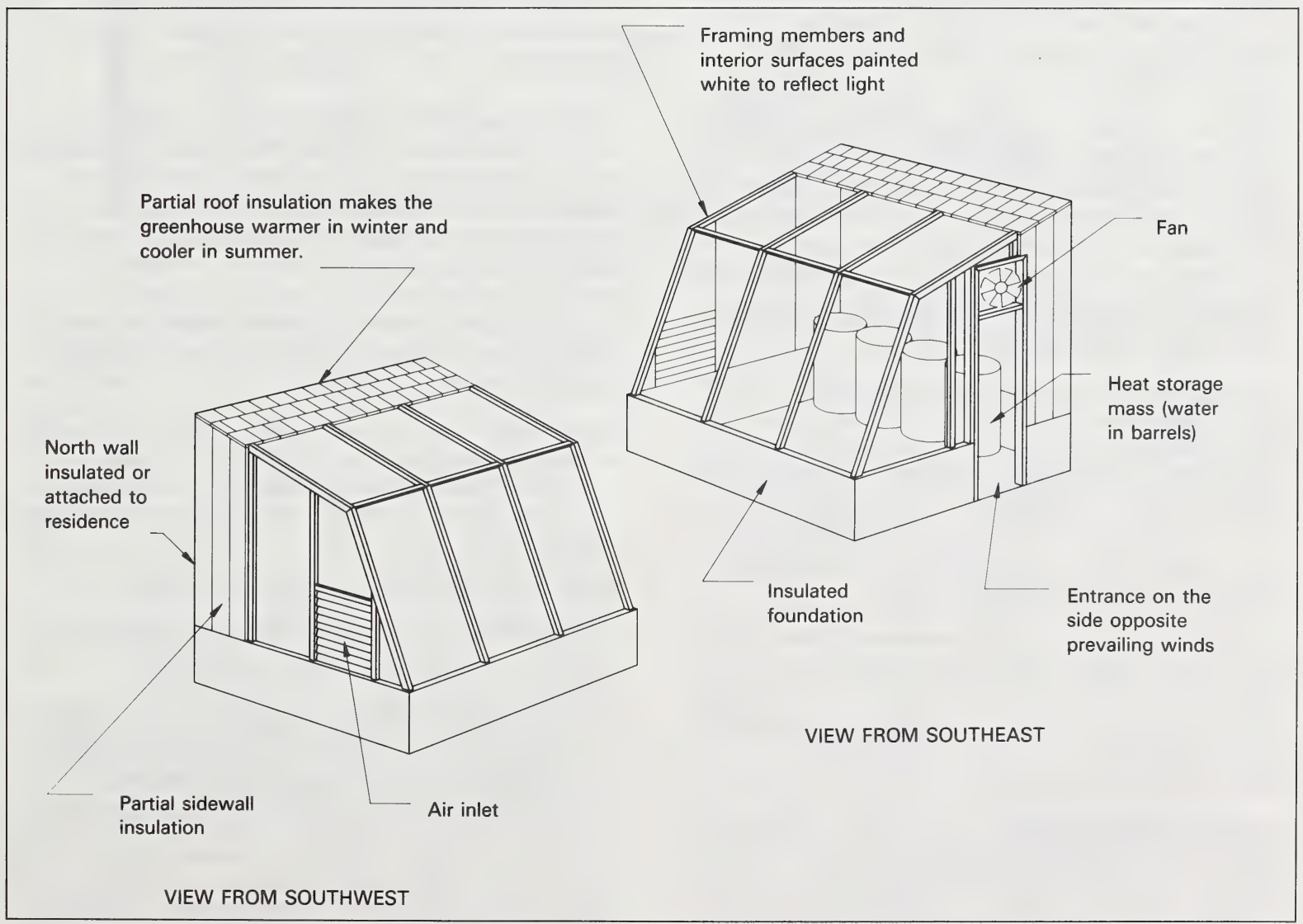

Figure 6. Typical solar greenhouse components 
Varying amounts of this infra-red radiation (depending on the thermal transmission factor) remain trapped inside the greenhouse, heating the air and other objects.

Even on a sunny winter day, a well-constructed, tightlysealed greenhouse can often capture enough heat to keep plants warm during the day. But, because a greenhouse by itself is a poor insulator, at night it rapidly loses the heat that it held during the day. Without supplemental heat, the temperature inside will fall too low for plants to survive.

The goal for developers of solar heating is to capture some of the excess heat during the day and store it for use at night. This sounds simple in theory; however, in practice it may be complicated.

The principles of solar energy can be applied to a full range of structures, from cold frames and other devices in the garden to the full scale permanent greenhouse. The greenhouse can be freestanding, but typically it is attached to the home or other building for convenience of access, simplified construction and potential supplemental heat for the residence. If possible, the attached greenhouse should enclose a window and/or a door connected to the home.

While the conventional greenhouse is generally operated year round and uses a large amount of fossil fuel to maintain ideal growing conditions, the solar greenhouse adapts to nature and is designed for a more specific or limited purpose. In the design stage of a solar greenhouse, the choice must be made between obtaining maximum plant production or maximum supplemental heat production from the greenhouse.

\section{Typical Uses of the Solar Greenhouse}

The Sunspace - During the winter, the sunspace collects heat for the residence. While not as efficient as a standard flat plate solar collector, it does collect heat, extend the residence living space and provide limited, season-extending growing conditions in the spring and fall. Plants are usually container-grown.

The sunspace often has vertical windows, little non-south facing glazing, and a reduced need for ventilation compared with a plant-growing greenhouse. A large mass for heat storage is not required, because heat produced in winter is delivered to the home, sometimes by a thermostatically controlled fan.

Extended Living Space - An attached greenhouse, separated from the house by sliding glass doors, may be used as an extension of the home living space. During cold sunny weather, extra heat from the greenhouse supplements the home's heating system and heat from the home heats the greenhouse at night. If desired, plants may be grown in containers. Energy conserving measures are used during the winter in the greenhouse and shading is employed during the summer. No heat storage is necessary during the cold months because the home takes all the extra heat, but storage may be used in spring and fall when extra heat is available. Supplemental heat or heat from the home is often needed during winter in the greenhouse.

Season Extender - The season extender greenhouse is used primarily to extend the outdoor growing season by several months in the spring and fall. Garden vegetables can be started early in the spring, and when transplanted outdoors they reach maturity sooner. In the fall, crops can be transplanted from the garden into large containers to continue harvest after frost. Insulation, night blankets or insulation panels, and a large thermal storage are needed to retain the day's heat; otherwise an auxiliary heating system may be necessary. This type of greenhouse is generally not used for plant production during the coldest part of the winter. Cold frames, hotbeds and window greenhouses are other low-cost alternatives for extending the growing season.

Year Round Plant Production - A greenhouse without supplemental heat has similar design requirements to the season extending greenhouse, except that it is more important that the south facing glazing receive maximum sunlight during the coldest part of winter. A small auxiliary heater will be needed to maintain a minimum temperature during very cold nights. Under Alberta conditions, some leafy green vegetables will tolerate these conditions as well as many ornamental crops.

A greenhouse using a supplemental heating system will provide ideal temperatures for maximum production. The use of solar heating principles and insulation techniques will greatly reduce the amount of fuel needed to heat the greenhouse.

\section{Solar Heating: Passive, Active, Hybrid}

The basic solar heating systems are passive, active and hybrid. In a passive system the building and its components collect and store the solar energy. No blowers, pumps or electrical equipment are used. This is usually the most cost effective way to use energy from the sun. Water barrels or rock walls are often used to store heat in greenhouses with passive heating systems.

Active solar systems typically have separate solar collectors and either pumps or blowers to transfer heat by means of a liquid or air from the collectors to a separate storage system. The same pumps or blowers or additional 


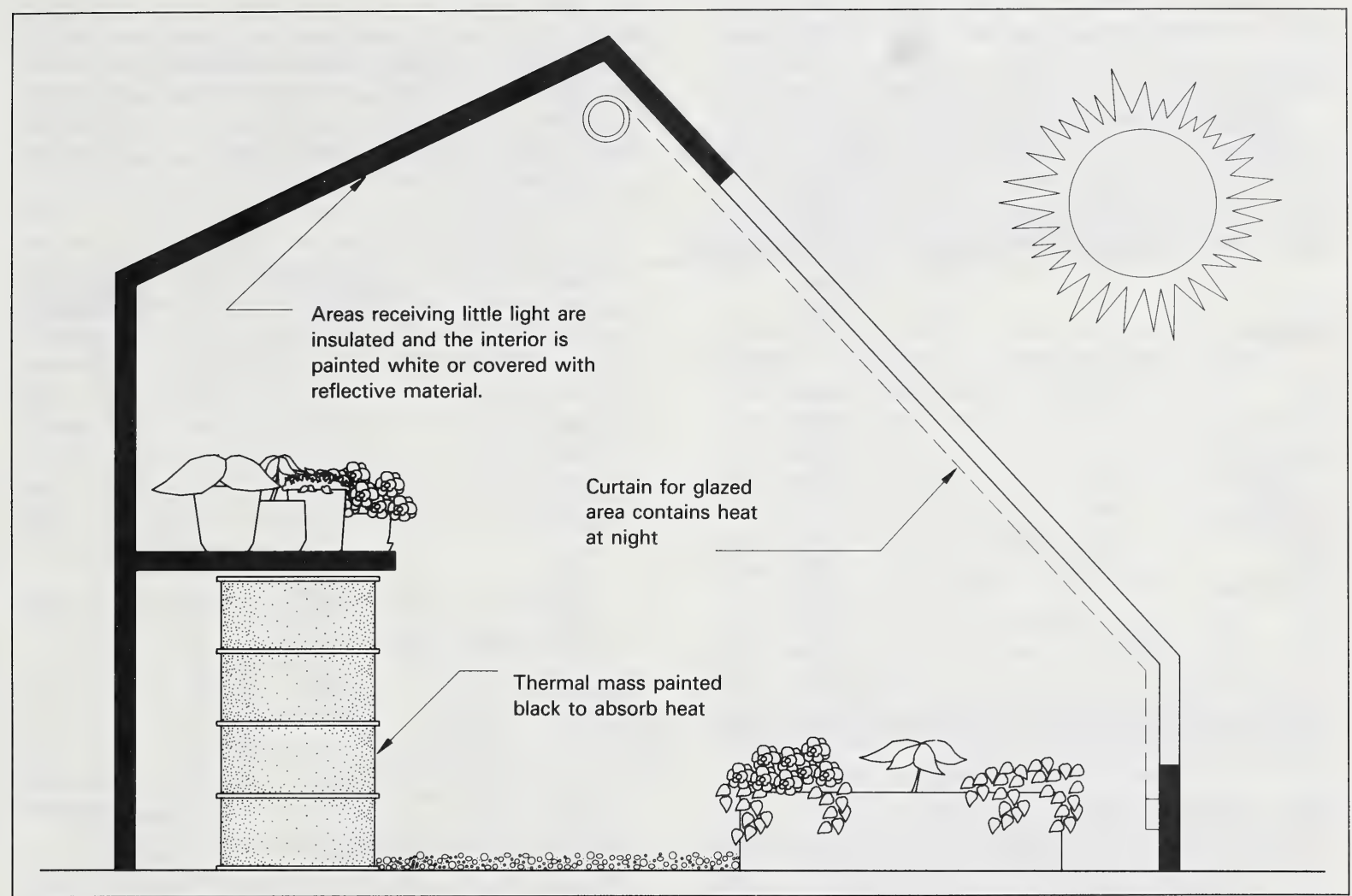

Figure 7. Passive solar system

ones may be needed to remove the heat from storage and distribute it within the greenhouse. A blower and duct system that transfers heat from the ridge of the greenhouse to a rock bed is an example of an active system.

A hybrid system may combine some of the features of both the active and passive systems. In an attached hobby greenhouse with a passive collector-storage wall of $220 \mathrm{~L}$ cans, a small fan may be installed to transfer heat to the home. The equipment cost and energy used to run the fan is small compared to the expense of operating an active solar system.

The Collector - A collector converts incident solar radiation (insolation) into thermal energy to heat air, water or other media, such as rocks, sand or gravel. Greenhouses are natural solar collectors and, through modification, can store heat trapped during the day for later use at night.

A greenhouse-collector has several advantages over an external collector. Construction costs are less, little additional land is required and little heat loss occurs in the transfer of heat from the greenhouse or from the heat storage to the home.

A greenhouse has several deficiencies as a collector. At times, it must be vented to remove excess heat and lower humidity levels to prevent disease. Insulation, internal blankets and double glazing should be used to hold the small amount of heat collected more effectively.

On the other hand, an external collector, oriented to face the sun directly, captures a higher percentage of the sun's heat and requires no venting. In its simplest form, an external flat plate collector is a large piece of black material that absorb the sun's rays. Heat is transferred to an anti-freeze solution, water or air, which passes over or through the collector. More heat can be captured by covering the front of the collector with more than one layer of glass or transparent plastic and insulating the back. Most external collectors have a high initial cost and are not used for heating hobby greenhouses.

Sunspaces are operated as solar collectors so few, if any, plants are grown in them. On sunny days, a sunspace 
may become hot. Then at night or whenever the temperature in the space drops below $20^{\circ}-23^{\circ} \mathrm{C}$, the sunspace is closed from the house; otherwise heat from the house will escape through the sunspace. But closing the sunspace at night often allows the sunspace to become cold, making it ill-suited to grow plants in. Heat Storage: Heat that is collected is normally stored for later use by warming a material such as a brick or concrete wall, water, small stones or a material that changes phases. On a weight basis, water can store more heat than any other commonly available material. To raise the temperature of $1 \mathrm{~kg}$ of water by $1^{\circ} \mathrm{C}$, it requires $4.18 \mathrm{KJ}$ of heat. This is the specific heat of water. In comparison, it takes only $0.8 \mathrm{KJ}$ of heat to raise the temperature of 1 $\mathrm{kg}$ of rock by $1^{\circ} \mathrm{C}$.

TABLE 3. Heat Capacities of Materials at Room Temperature.'

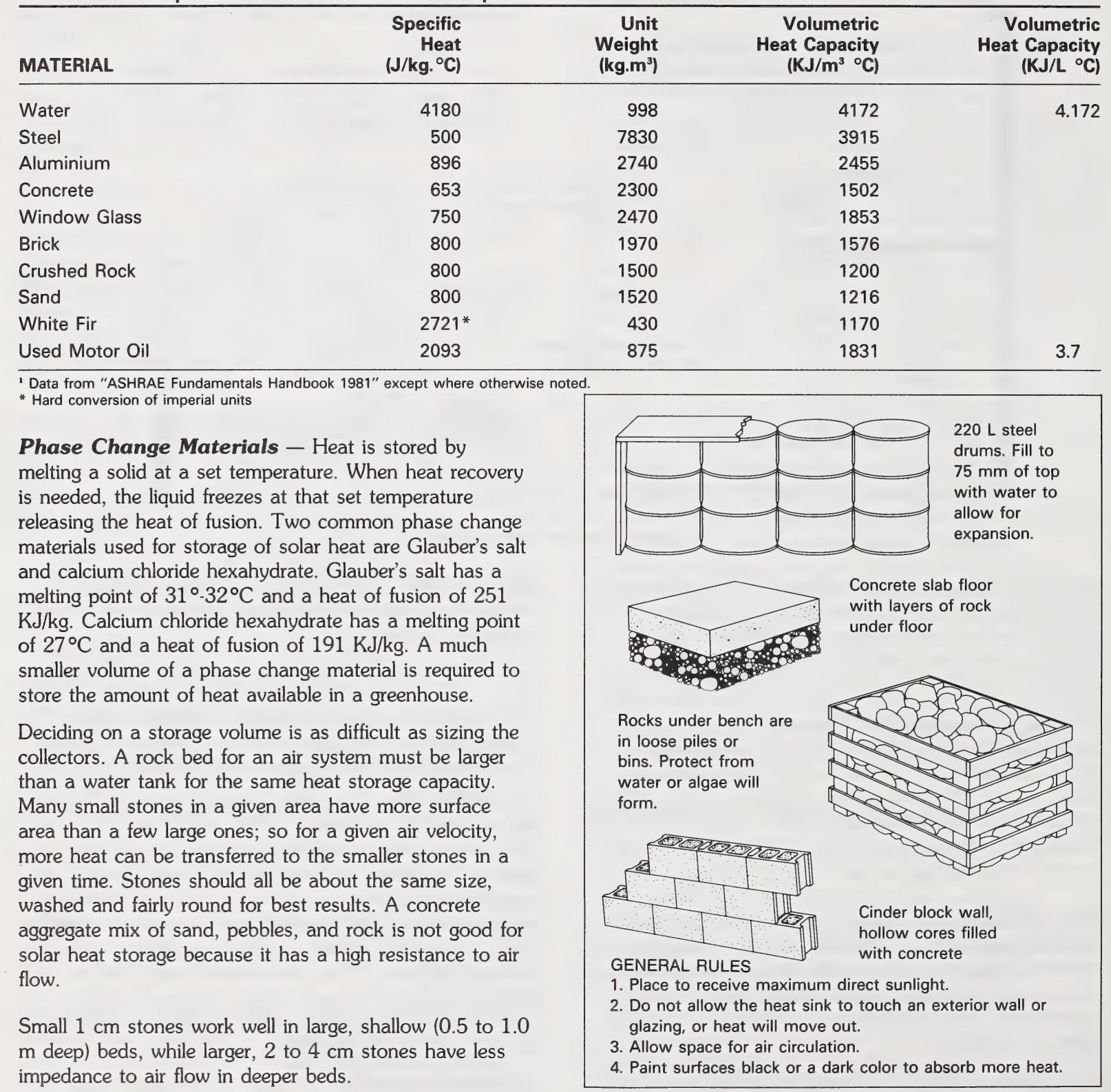

Figure 8. Types of solar heat storage 


\section{Example: Sizing a Heat Storage}

The storage should have enough capacity to heat the greenhouse for an average winter night. For example, a well insulated solar greenhouse, with 15 square metres of double wall south facing glazing, loses about $190 \mathrm{KJ} /$ hour for each degree celsius difference there is between the inside and outside temperature. If the average outdoor temperature for the 14 hour overnight heating period is $-7^{\circ} \mathrm{C}$ and the inside temperature is $7^{\circ} \mathrm{C}$, about 37,240 $\mathrm{KJ}$ will be needed $\left(190 \mathrm{KJ} / \mathrm{hr} \times 14^{\circ} \mathrm{C} \times 14\right.$ hours).

Storage for that much heat can be provided with one hundred and sixty-eight $4 \mathrm{~L}$ cans, thirty-four $20 \mathrm{~L}$ cans, three $220 \mathrm{~L}$ drums or a $0.6 \times 0.9 \times 4.3 \mathrm{~m}$ rock bed. The storage is assumed to cool $17^{\circ} \mathrm{C}$ (from $27^{\circ}$ at night to $10^{\circ}$ in the morning (table 4). There is some storage of heat in the soil, benches and plants that will help heat at night. This will tend to reduce the amount of water or rock storage needed.

TABLE 4. Heat Capacity of Water Storage Containers.'

\begin{tabular}{lcrcr}
\hline & & \multicolumn{3}{c}{ Heat Capacity, KJ } \\
\cline { 3 - 5 } & $\begin{array}{c}\text { Water } \\
\text { Temp. } \\
\text { C }\end{array}$ & $\begin{array}{c}\text { 220 L } \\
\text { Drum }\end{array}$ & $\begin{array}{c}\text { 20 L } \\
\text { Square } \\
\text { Can }\end{array}$ & $\begin{array}{c}\mathbf{4 . 0} \text { L } \\
\text { Can }\end{array}$ \\
\cline { 2 - 5 } Passive & 15.6 & 4842 & 443 & 84 \\
Systems & 21.1 & 9673 & 875 & 179 \\
& 26.7 & 14514 & 1319 & 264 \\
& 32.2 & 19345 & 1762 & 348 \\
\hline Active & 37.8 & 24187 & 2205 & 443 \\
Systems & 43.3 & 29028 & 2637 & 527 \\
& 48.9 & 33859 & 3080 & 612 \\
\hline
\end{tabular}

' Assumes minimum greenhouse temperature of $10^{\circ} \mathrm{C}$ and uniform water temperature throughout containers which is usually not true in larger containers.

The amount of heat that is collected in the storage will also depend on how many plants are in the greenhouse. In a greenhouse full of plants, about 50 per cent of the solar energy entering is used to evaporate water from the leaf and soil surfaces. For this reason a greenhouse used as a sunspace should not have any plants if maximum collection is desired.

Storage Location - There are advantages to locating the heat storage inside the greenhouse. Any heat lost from the storage still heats the greenhouse, no losses occur when heat is circulated from the storage to the greenhouse and little additional land is required for the storage. Locate the storage to receive maximum direct sunlight.

Heat Transfer - The amount of heat transferred to the greenhouse from a hot water heater or storage tank is almost proportional to the area of the heater or tank surface and the water temperature. Values for typical passive storage containers are shown in table 4 .

A $4.0 \mathrm{~L}$ can will lose its heat about six times faster than a $220 \mathrm{~L}$ drum. For example, a $4.0 \mathrm{~L}$ container may release its heat in three hours, whereas a $220 \mathrm{~L}$ drum takes about 20 hours to lose its heat. Generally the $20 \mathrm{~L}$ size, if they are stacked tightly, or the $220 \mathrm{~L}$ drums work best because they hold more water per unit of surface than the $4.0 \mathrm{~L}$ containers.

Controls - An active heating system, such as a rock storage with blowers or a water tank with external collectors, requires a control system. Controlling everything to operate at the right time or temperature is a challenge. The heat transfer fluid should not be circulated to the collector at night or when there is not enough sunlight to heat it. Water or air should not be circulated from storage to the greenhouse if the storage temperature is lower than the greenhouse temperature.

Structural Variations for Maximum Use of Solar Energy-Greenhouses can use solar energy more efficiently by varying some aspects of conventional greenhouse construction. Every effort possible should be made to reduce heat loss and to build the greenhouse to take maximum advantage of the solar energy available.

Slope of South Facing Glazing and Light TransmissionThe maximum amount of energy passes through the glazing when it is perpendicular to the sun's rays. This only occurs for an hour or so on two days of the year, once in the spring and once in the fall. The rest of the time part of the energy reflects off the glazing. If the greenhouse will be used all winter long, the angle of the south-facing glazing will be determined for the period of January and February when the combined effect of temperature and reduced solar radiation is most severe. Other factors, such as weather patterns (e.g. foggy mornings in spring, etc.), physical site factors, obstructions and horticultural considerations, will also influence the greenhouse design. One rule of thumb is to add 15 to your latitude to get the desired slope. For northern areas the best roof angle is between $35^{\circ}$ and $65^{\circ}$ from the horizontal. If a large percentage of the solar radiation in your area is diffuse, choose an angle from the lower end of the range.

If you are designing your own greenhouse, use the following guidelines when selecting the angle.

Use a steep angle:

- in areas where there is a greater percentage of direct sun,

- for narrow greenhouses,

- for greater solar collection during the winter,

- for less overheating during the summer. 
Use a shallow slope:

- in areas with cloudy weather,

- in wide houses,

- in a greenhouse built for spring and fall use,

- to allow an attached greenhouse to fit under the eave,

- to reduce heat loss.

Vertical glazing is easier to construct and seal, it also reduces overheating in summer.

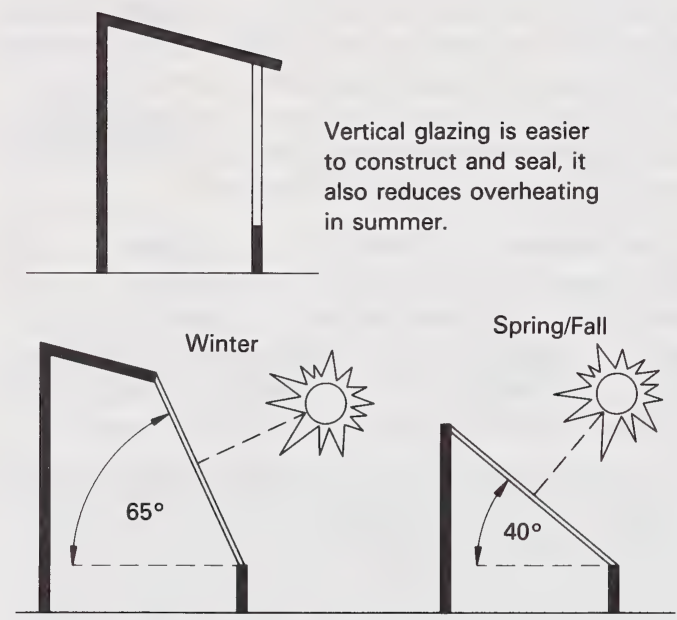

For maximum production in winter a sloped south glazing will increase light levels.

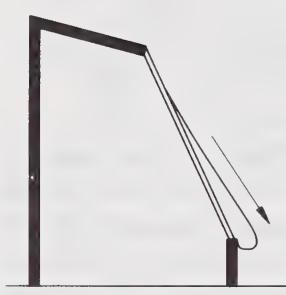

A steep slope allows snow to slide off.

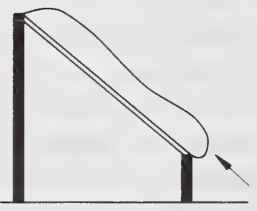

Low roof slopes tend to hold dirt and snow.

Figure 9. Slope of the south-facing glazing

Solid North Wall - During the winter, much of the light comes from the south, especially at Alberta latitudes. It is possible, therefore, to replace the heat-wasting north glazing with a well-insulated wall. Lean-to greenhouses are ideally suited to this purpose. It is also possible to insulate a small portion of the most northerly section of the roof to further reduce heat loss with little change in the amount of winter light. To prevent the plants from straining toward the south wall (light source), the north wall should have a reflective inner surface (e.g., aluminum foil or paint) to bounce light onto the plants from behind. This can increase the amount of light and solar energy in a greenhouse by 20-30 per cent on a sunny midwinter day. Double Glazing - It is possible to reduce heat loss through the glazed surface of a greenhouse by using two layers of glazing materials with a dead air insulating space in between, or by applying insulation at night to either the inside or outside of the structure. Special double-walled or honeycomb acrylic plastics or two layers of polyethylene are common methods of double glazing.

Extra insulation can be provided at night (when heat requirements are greatest) by rolling insulating blankets over the greenhouse structure, by snapping rigid styrofoam sheets on the inside of the structure or by stretching a "heat curtain" across the eaves to produce a flat "false" ceiling with a large insulating air space above.

Commercial heat curtains are made of nylon or a cottonpolyester blend and have an aluminum facing to reflect the heat inward. Possibilities for preventing heat loss are only limited by your imagination. Sound Construction-A greenhouse should be well-constructed with few gaps or air leaks between structural members or sheets of glazing materials, which can allow heat to escape and cold air to enter (infiltration). Poorly constructed houses may allow two complete air changes per hour because of air gaps, whereas in a well-constructed unit only half the air is changed per hour, resulting in a much lower heat loss.

If you plan to operate the greenhouse during the winter, it is also recommended that you build a double entrance so that the resulting airlock buffers cold drafts when the greenhouse is entered.

Brace Research Institute Greenhouse-Figure 10 illustrates a plan that incorporates all these structural variations for maximizing solar energy use, which was developed by the Brace Research Institute at Macdonald College.

In the experimental unit at Montreal, a reduction of 30-40 per cent in the heating requirements was found when compared with a standard gable double-layered, plastic-covered greenhouse. The University of Alberta's Devonian Botanic Garden near Edmonton, has utilized a similar design. 


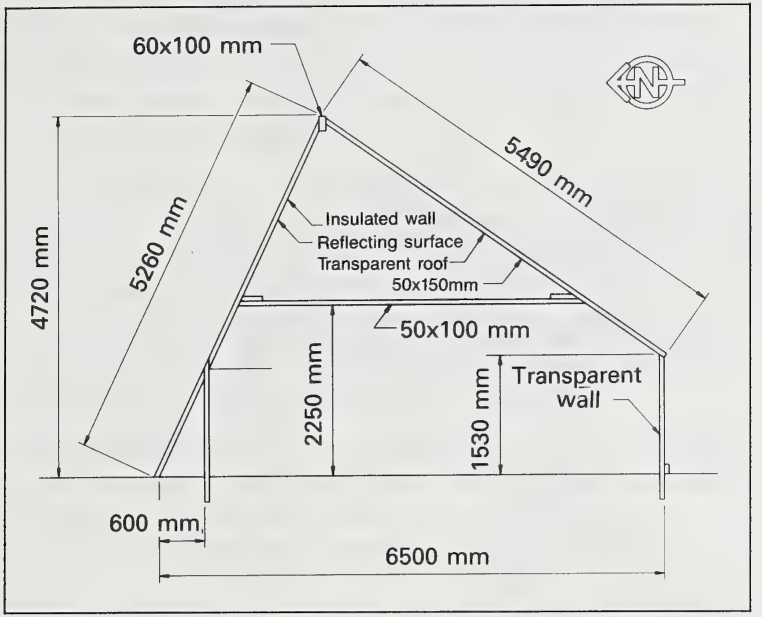

Figure 10. Section view of Brace experimental greenhouse

\section{Construction}

\section{Foundations}

General - A small greenhouse does not require much structural support. The foundation, however, should allow for convenient attachment to the frame, anchor the greenhouse securely to the ground and be insulated. Before laying the foundation, make sure that there is good soil drainage. Excessively wet conditions can result in frost heaving of the structure. This will be much less of a problem if you operate the greenhouse year-round because the ground around the foundation will not freeze.

Construction details for two types of small greenhouse foundations are contained in figure 11 , a concrete foundation and a treated-wood foundation. The size shown is for a typical small greenhouse and, of course, may be adjusted to suit one's needs.

Treated-Wood Foundation - This foundation is also referred to as a post-pier foundation. It is slightly more expensive than concrete, but easy to construct and relatively well insulated. Pressure-treated wood is récommended, preferably wood treated with acid copper chromate (ACC) or chromated copper Arsenate (CCA) salt-based preservative, which are the same material approved and used for wood basements. Penta or creosote preservative is toxic to plant roots if plants are grown near the foundation. For more information on treatment of wood for use in the greenhouse, see this page.

To construct the foundation, either square-sawn or round fence posts are set in the ground at $120 \mathrm{~cm}$ centres. The foundation section is then built from treated plank, preferably tongue and groove planks. Extra insulation can be added by attaching $50 \mathrm{~mm}$ rigid foam slabs to the inside of the foundation. This is recommended if the greenhouse is operated year-round. As an alternative, a squared timber could be set on the ground as a less permanent type of foundation. It should be further anchored to prevent wind uplift.

\section{Concrete Foundation - A shallow concrete} foundation, like that shown, is subject to frost heaving, but this is not normally a problem for this small a building in most soil conditions. It is recommended that the foundation be reinforced all around by two continuous reinforcing rods to prevent cracking because of frost action. Lap the rods $400 \mathrm{~mm}$ at splices, usually by bending and lapping the rods at the corners.

A concrete foundation is cold: it should be insulated by installing $50 \mathrm{~mm}$ thick slabs of rigid foam, as shown. A good construction technique is to set the foam insulation inside the forms before pouring the concrete. The fresh concrete will then be tightly bound to the insulation. Bolts should be set in the concrete to hold the wooden sill plate in place. Insulating the foundation with rigid foam insulation will prevent frost penetration at ground level, as well as reduce heat loss. Facing the foam with $3 \mathrm{~mm}$ cement asbestos board will prevent deterioration or damage to the rigid insulation.

Concrete blocks can be substituted for a poured concrete foundation. To be most durable, the blocks should be placed on a concrete footing.

\section{Framework}

Greenhouses are currently being made of all kinds of materials, including wood, aluminum and steel. The advantages, as well as disadvantages, of each for specific use are listed.

Wood - Wood is easy to work with, is relatively inexpensive, and contributes to a uniform greenhouse temperature because it does not cool down quickly. The soft woods (cedar, redwood and pine) are easier to work with than the hard woods (oak, maple and birch). For greater durability, soft woods such as redwood and cedar, which are more resistant to decay, should be used. All wood used in a greenhouse should be treated with a preservative, especially if wood that is less resistant to decay is used.

Preservatives fall into two basic categories: oil-borne and water-borne salt-type. Oil-borne preservatives such as creosote and pentachlorophenol (penta) should not be used in a greenhouse because they are highly toxic to plants. Most water-borne, salt-type preservatives are essentially non-toxic. Of the water-borne preservatives, 

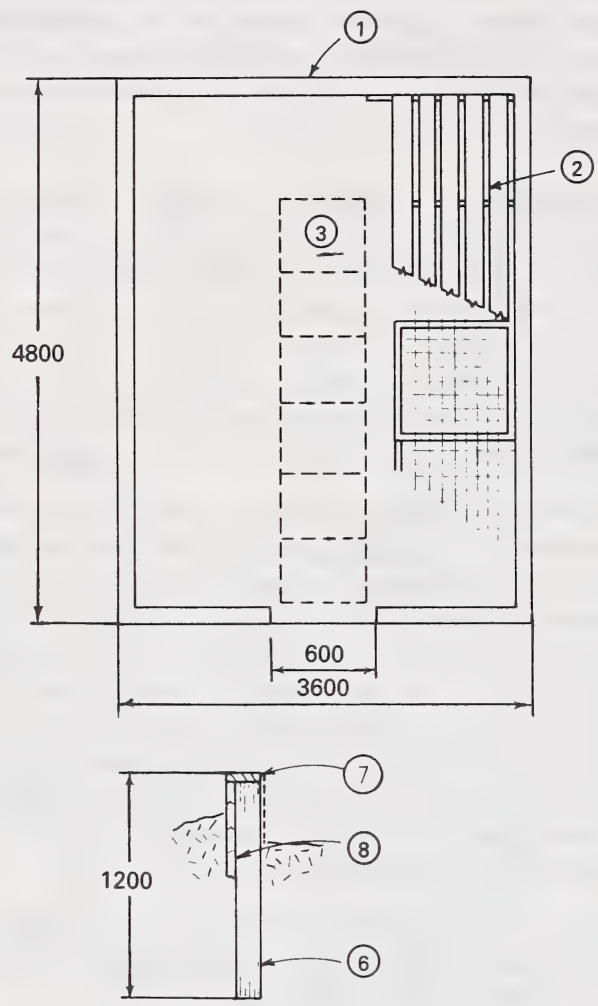

cross section of post

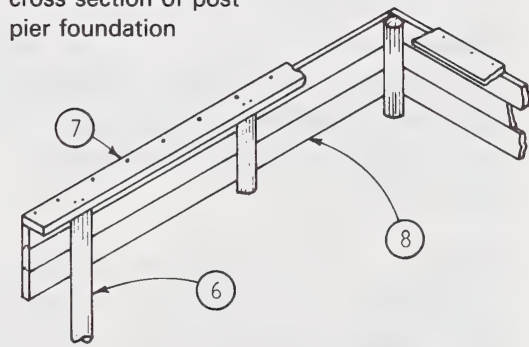

side view of post pier foundation
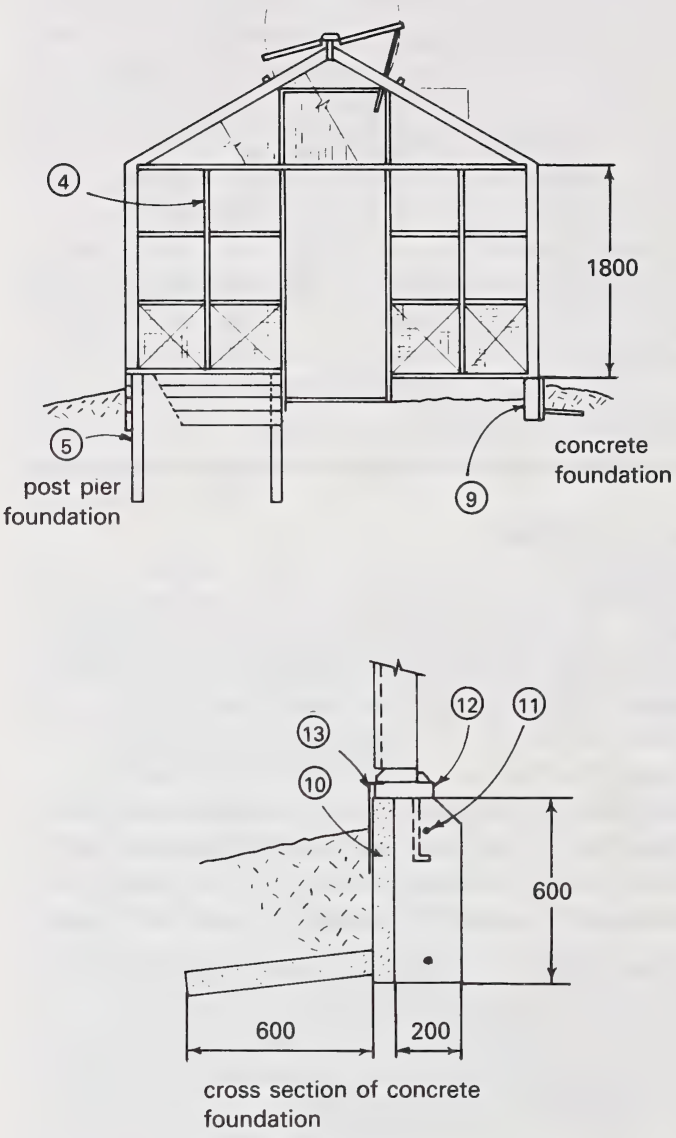

All dimensions given in $\mathrm{mm}$
1. Foundation (two types detailed)

2. Benches or soil bed growing areas

3. Sidewalk blocks or gravel path

4. Typical end wall framing

5. Post pier foundation

6. Treated posts $1200 \mathrm{~mm}$ o.c.

7. $38 \times 140 \mathrm{~mm}$ top plate

8. $38 \times 140 \mathrm{~mm}$ tongue and groove plank ( 3 on edge with tongues up).

(pressure treated with non-penta preservative)
9. Alternate concrete foundation.

10. $50 \mathrm{~mm}$ rigid extruded foam insulation.

11. $10 \mathrm{M}$ rebar. Continuous bend and lap at corners.

12. Treated bottom plate. Rabbet blocking if glass is used.

13. Metal flashing to below ground.

Figure 11. Foundations 
acid copper chromate (Celcure), chromated zinc chloride (CZC), chromated copper arsenate (CCA) and fluoridechromate copper arsenate phenol (PCAP) are the most common. Railway ties are treated with creosote and are not suitable for foundations.

The effectiveness of wood treatment is directly related to the amount of preservative retained in the wood. In this respect, commercially pressure-treated wood is the best. Cold-soaking or immersing the wood in preservative is effective but difficult to do. Spraying or painting is least effective and not recommended except as a last resort: if used, several soaking coats should be applied.

Pressure-treated wood, the type sold for wood basements, is readily available and though it is 2 to 3 times the cost of common framing lumber, it is well worth the extra cost.

Steel - Steel pipe provides a more solid structure than wood and allows more light into the greenhouse. Steel, however, must be painted or it will rust. Wood and steel are the materials most often required in following many of the available hobby greenhouse plans.

Aluminum Alloy - In the long run, aluminum alloy is the most practical structural material. It is light, strong, has a high degree of light reflectiveness and requires little, if any, maintenance. Aluminum alloy, however, does transmit heat more readily than wood, resulting in greater heat loss. Because of aluminum alloy's greater strength, it also allows the use of smaller supports. The smaller the structural supports the less shade they will cast.

Aluminum is the material used most often used in making prefabricated greenhouses.

\section{Greenhouse Coverings}

The sun radiates both visible and invisible wavelengths of energy. Most greenhouse crops grow best in light of wavelengths between 400 and 700 nanometres. This waveband is called photosynthetically active radiation or PAR. Greenhouse glazings readily transmit these short waves of visible light.

Plants and soil also radiate energy, but with a very long wavelength. Glass and fibreglass reflect, rather than transmit, most of this long wave energy. This property of glass is called the "greenhouse effect". Some plastics, particularly polyethylene, transmit a large portion of this long wave radiation. This property causes polyethylene covered houses to cool faster at sunset. Water condensation on the polyethylene, however, reduces this radiant heat loss.

Greenhouses also trap heat because they are an enclosed space. Only about a quarter of the temperature rise in a greenhouse is due to the greenhouse effect. The remaining three quarters of the temperature rise is due to the air being trapped in an enclosed space (figure 12).

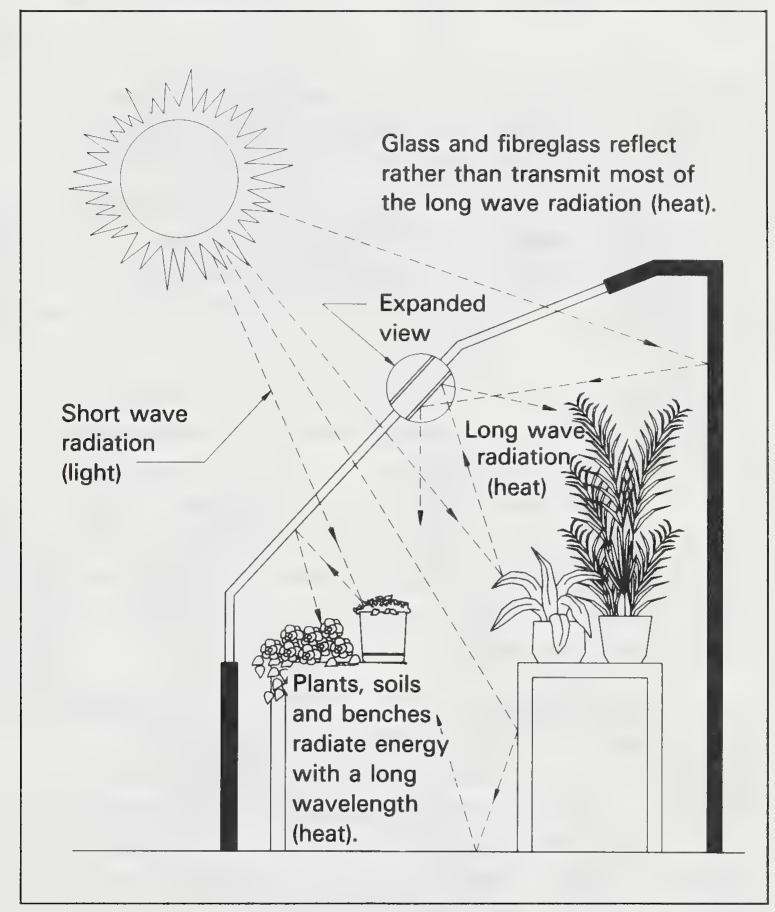

Figure 12. The greenhouse effect

Glass - Glass is the standard against which other covering materials are measured. Glass houses are attractive, permanent, and expensive. Glass is durable but breakable, so double strength or tempered glass normally is used for greenhouses. Tempered glass is stronger and, on widely spaced supports, allows more light to enter. Because glass-covered houses are difficult to fabricate, they should be built by a greenhouse manufacturer or purchased in kit form.

Sunspaces are often built using windows or sliding glass doors. They are readily available in several sizes. Wood framed windows are preferred over metal framed windows because they insulate better.

The proportion of radiation which enters the greenhouse depends on both the chemical composition and the thickness of the transparent material. The normal glass and plastic used for greenhouses not only reduce the intensity of solar radiation but also have a selective effect and allow only certain parts of the light spectrum to penetrate. Common glass transmits only radiation with wavelengths between 320 nanometres $(\mathrm{nm})$ and around $2800 \mathrm{~nm}$. Visible light ranges from 360 to $760 \mathrm{~nm}$. 
Most glass contains iron, which absorbs light. Low iron glass transmits about 90 per cent of incoming solar radiation while typical window glass transmits 83 per cent.

Plastics - A large variety of plastic glazings are available. Generally plastics are resistant to breakage, lightweight and relatively easy to install. Most plastics, however, degrade under sunlight. The quality of plastic glazings varies widely, so it is important to buy a greenhouse grade plastic, preferably with a written guarantee of its life. Characteristics of various plastics are listed in table 5 .

Polyethylene, fibreglass and tempered glass diffuse or scatter light as it passes through while polycarbonate, acrylic, polyester and glass are clear and allow radiation to pass through directly. Diffuse light can benefit plants both by reducing excess light on the upper leaves and by increasing the amount of light reflected into the lower leaves. Too much direct sunlight on the upper leaves can overheat the plant, reducing photosynthesis.

Acrylic is very transparent, very resistant to weathering and breakage, and can be used as a curved panel. However, acrylic is expensive, flammable and easily scratched. The long-wave thermal radiation absorption and the ultra-violet radiation transmission of acrylic is higher than glass. Ultraviolet radiation keeps plants shorter by suppressing cell elongation.

Double-layer acrylic glazing has some advantages when used for greenhouse glazing. It is a translucent material that transmits about 83 per cent of the light and reduces heat loss by 30 to 40 per cent of that through a single layer.

Double-wall polycarbonates (Qualex and Tuffak Twinwall) transmit 75-80 per cent of the light and offer the same 40 per cent energy conserving properties as other double-walled materials.

Polycarbonate panels usually are more flexible, resist impact better and are less expensive than acrylic panels, which are thicker. Thin polycarbonate panels can be bent during construction to fit a curve while the same thickness of double layer acrylic would have to be heat formed. Acrylic maintains high transparency throughout its life while polycarbonate starts turning yellow and losing transparency within a year. Qualex, according to the manufacturer, loses about one per cent of its ability to transmit light each year over its approximately ten year life.

Fibreglass - Houses covered with fibreglass reinforced polyester panels (FRP) are durable, attractive and moderately priced. FRP is more resistant to impact than glass. It transmits slightly less light than glass and weathering further reduces light transmission. It is not completely transparent and consequently not as attractive as glass. Fibreglass is not a good glazing for growing crops with high light requirements in areas with less than 40 per cent sunny days in the winter.

Fibreglass panels are easier to cut and fit than glass, and they can be used to cover almost any house. Either corrugated or flat panels are available. Corrugated panels require commercial sealing strips to stop drafts between corrugations. Flat FRP is attractive but needs support every 45 to $60 \mathrm{~cm}$ or it sags. Supports create more shade. Fibreglass, like many plastics, sustains a flame and burns quickly when it's windy. Fortunately, except for heaters and propane torches, little flame producing or flammable material is used in greenhouses. But be careful with fire near fibreglass.

Only buy fibreglass that is made for greenhouse use. Store fibreglass vertically and in a dry, well ventilated area. Moisture caught between sheets of fibreglass can cause staining. Acrylic or fluorocarbon (Tedlar) coated fibreglass is the best kind and should last for ten years or more. Do not use colored or lower grade panels. Plants do not receive enough light through colored panels and low grade panels darken rapidly with age.

Polyethylene - Polyethylene film used to cover greenhouses is inexpensive, but temporary. Polyethylene houses are less attractive and need more maintenance than other styles of greenhouses. Clear polyethylene, 4 to 6 mils $(0.1$ to $0.15 \mathrm{~mm})$ thick, is used because it is readily available and inexpensive. Unfortunately it is easily destroyed by ultraviolet (UV) radiation from the sun.

Polyethylene treated with a UV inhibitor will last 12 to 24 months longer than untreated polyethylene. Several companies now offer UV inhibited film (Monsanto 602 or 603, Ethyl Visqueen, and Arco Tufflite 3) that lasts two to three years as a greenhouse cover.

The wider the sheets of glazing material and the fewer structural framing members needed for support, the greater the light transmission will be. The low structural shading factor and low initial cost account for the high popularity of polyethylene film.

Heat loss can be reduced by 30 to 40 per cent by applying two layers of plastic film. However, two layers transmit 87 per cent or 75 per cent of available light when new. Because sunlight degrades the film rapidly, light transmission through two layers may be down to 65 per cent after a year or two. The framework lowers transmission even further. 


\begin{tabular}{|c|c|c|c|c|}
\hline 总 & 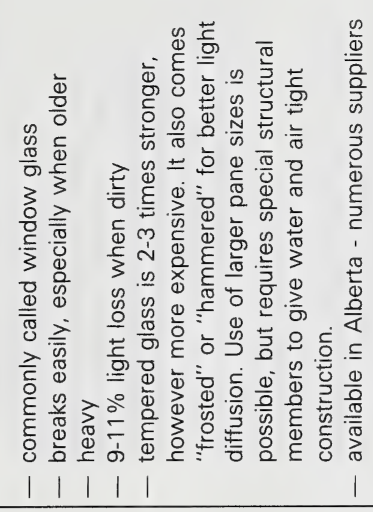 & 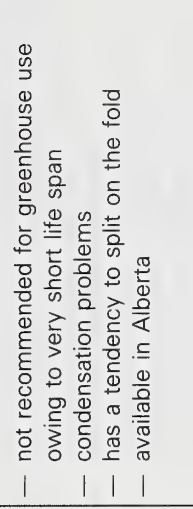 & 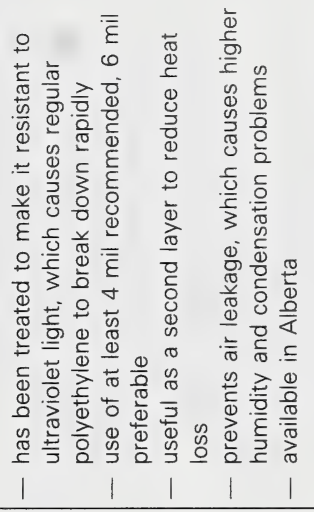 & 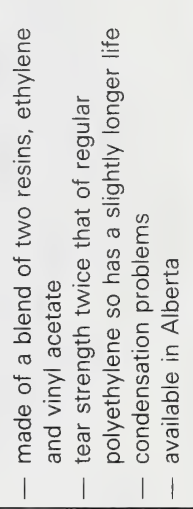 \\
\hline 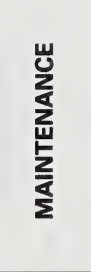 & 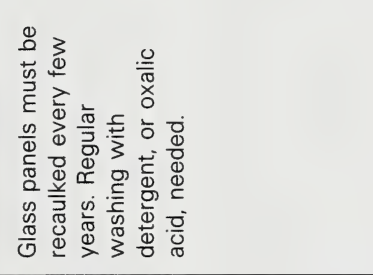 & 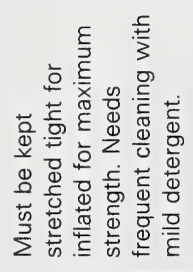 & 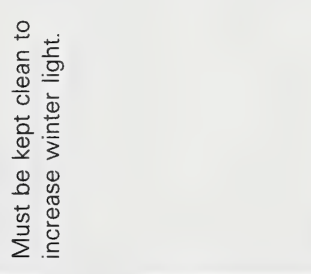 & 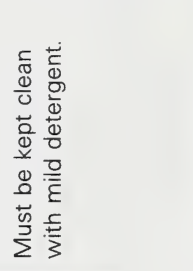 \\
\hline$\frac{\sum}{\bar{z}}$ & $\begin{array}{l}\text { 吾 } \\
\text { 总 }\end{array}$ & 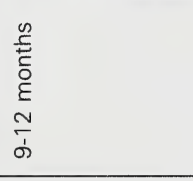 & $\begin{array}{l}\stackrel{\infty}{\infty} \\
\stackrel{\infty}{\infty} \\
\stackrel{N}{\perp}\end{array}$ & $\begin{array}{l}\stackrel{\infty}{\infty} \\
\stackrel{\infty}{\infty} \\
\stackrel{\sim}{N}\end{array}$ \\
\hline 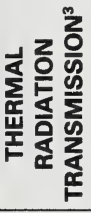 & $\begin{array}{ll}\forall & 0 \\
\forall & 0\end{array}$ & $\infty$ & $\curvearrowright$ & $\bar{r}$ \\
\hline 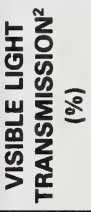 & 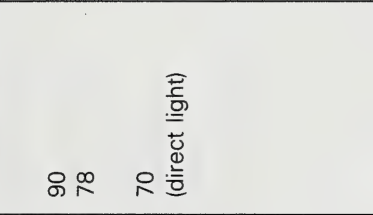 & 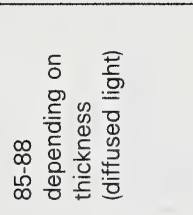 & 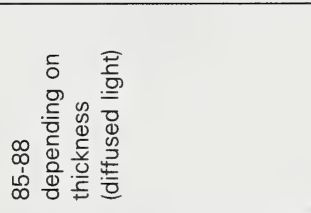 & 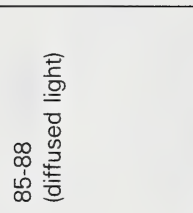 \\
\hline 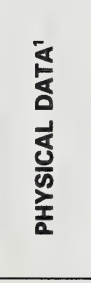 & 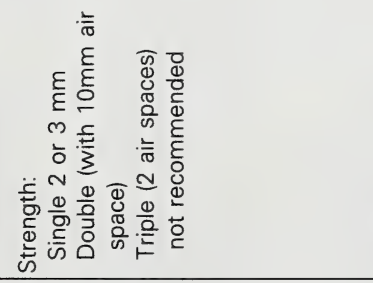 & 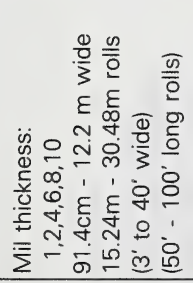 & 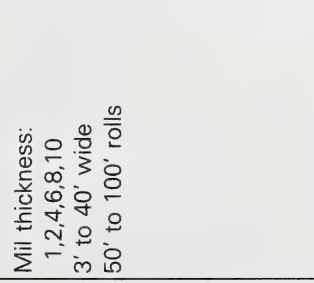 & 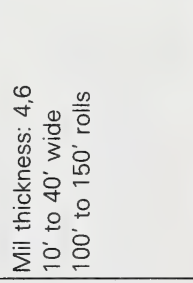 \\
\hline 怤 & \્ & 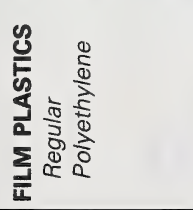 & 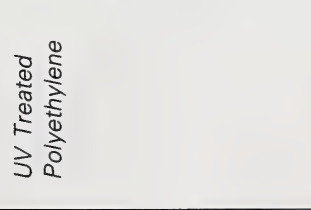 & 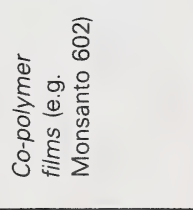 \\
\hline
\end{tabular}




\begin{tabular}{|c|c|c|c|c|c|}
\hline 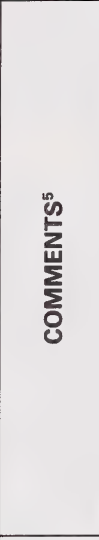 & 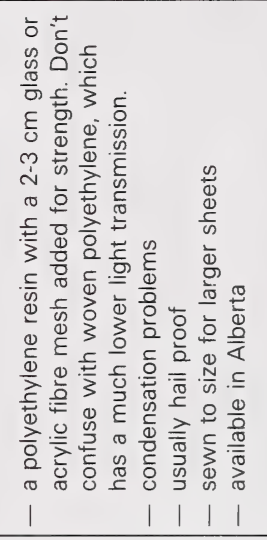 & 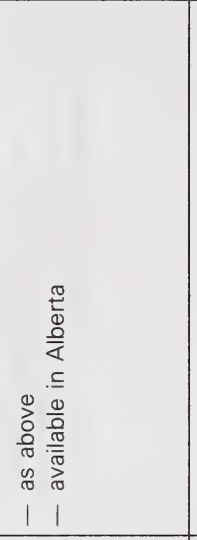 & 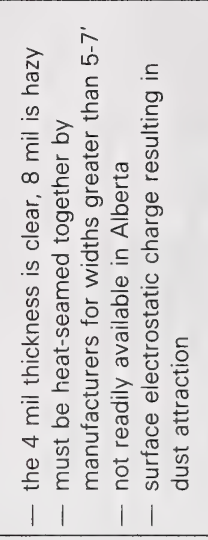 & 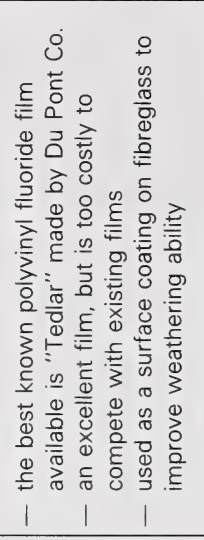 & 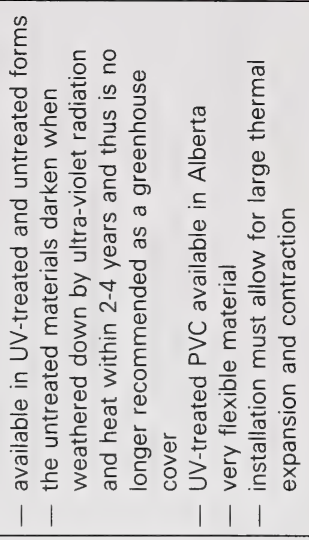 \\
\hline 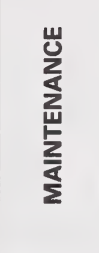 & 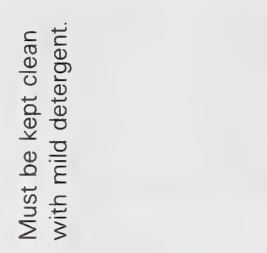 & 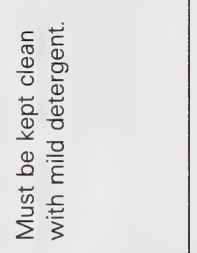 & 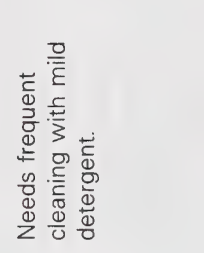 & & \\
\hline 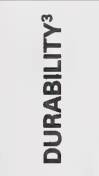 & $\begin{array}{l}\frac{\infty}{\hbar \pi} \\
\stackrel{\infty}{\infty} \\
\sim\end{array}$ & 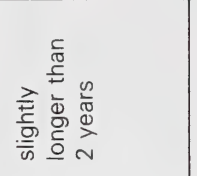 & 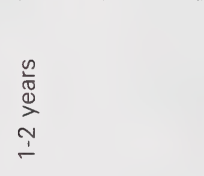 & 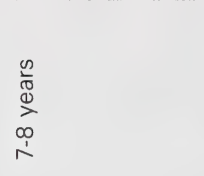 & 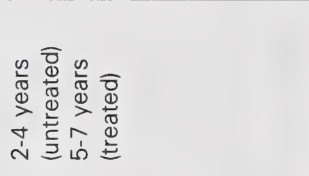 \\
\hline 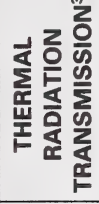 & $\stackrel{\mathscr{R}}{\circ}$ & & б & ల్ల & 0 \\
\hline 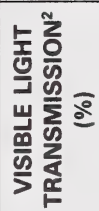 & 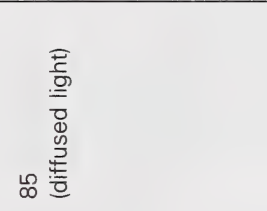 & $\stackrel{\infty}{\infty}$ & 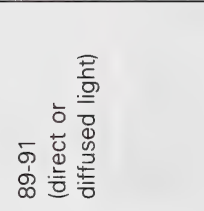 & $\tilde{\sigma}$ & 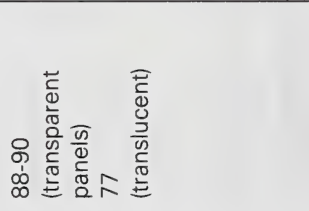 \\
\hline 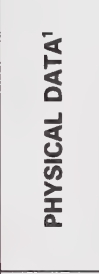 & 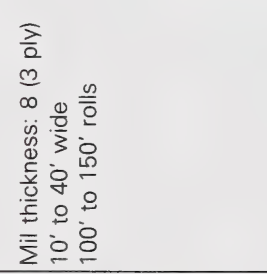 & & 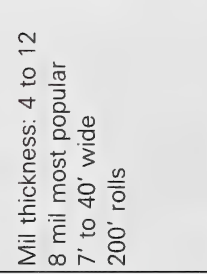 & 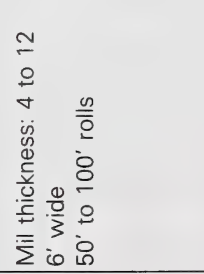 & 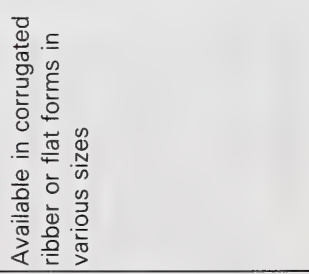 \\
\hline 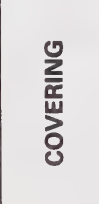 & 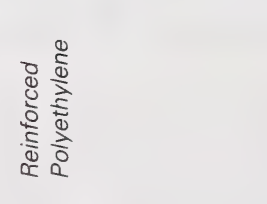 & 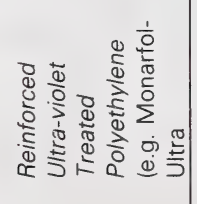 & 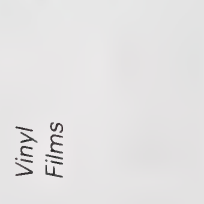 & 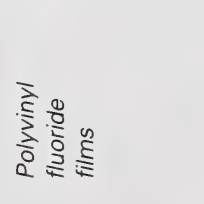 & 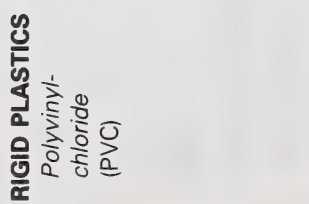 \\
\hline
\end{tabular}




\begin{tabular}{|c|c|c|c|c|}
\hline & 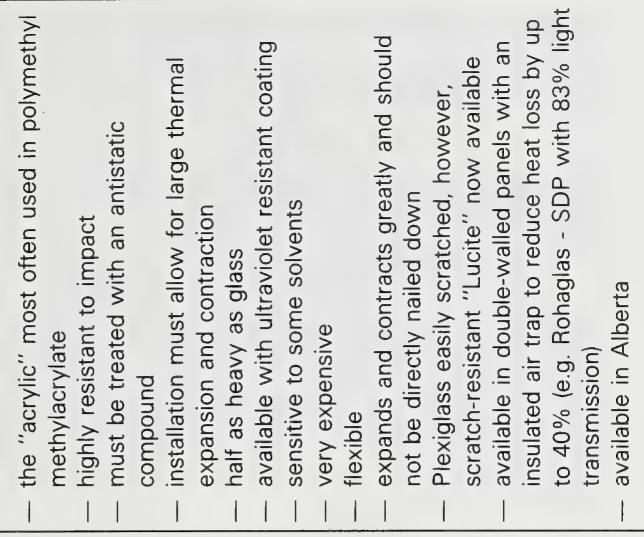 & 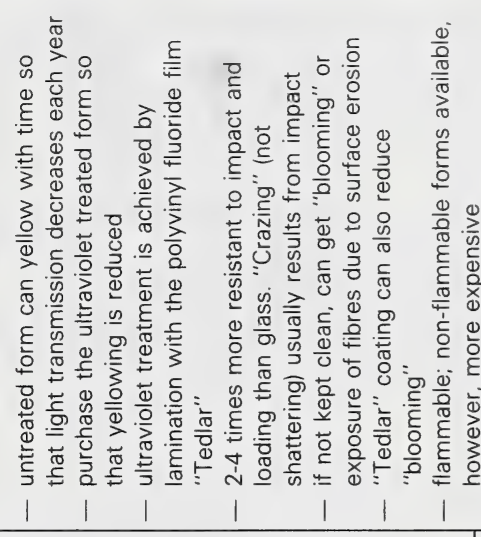 & 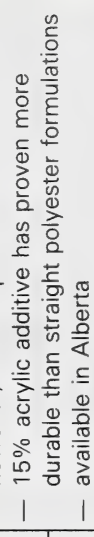 & 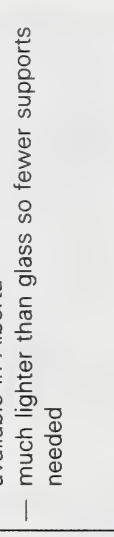 \\
\hline 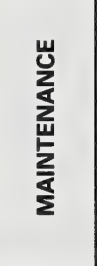 & 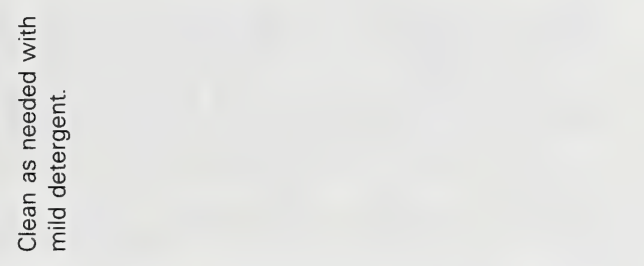 & 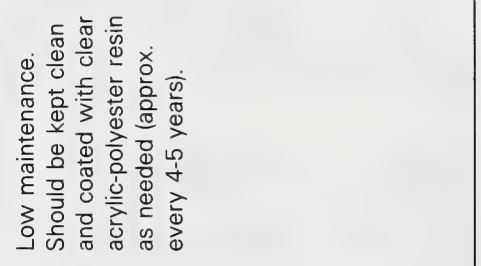 & & \multirow{6}{*}{ 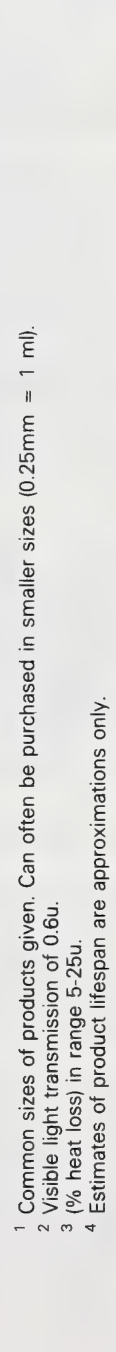 } \\
\hline 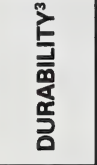 & 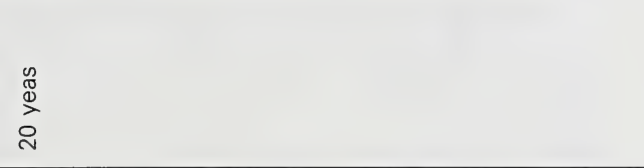 & 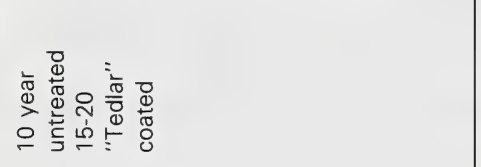 & & \\
\hline 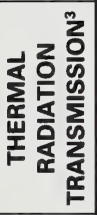 & $\stackrel{\infty}{0}$ & $\stackrel{10}{0}$ & & \\
\hline 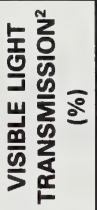 & 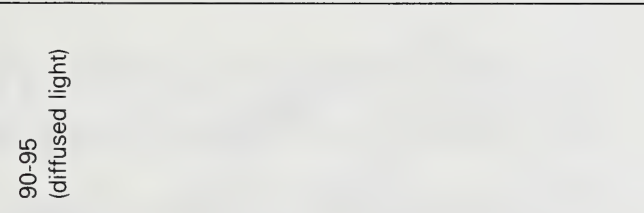 & 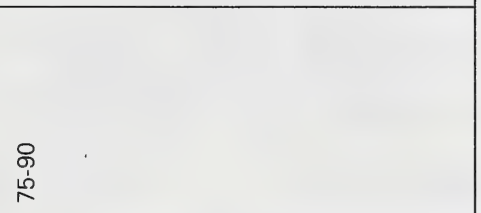 & & \\
\hline 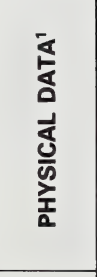 & 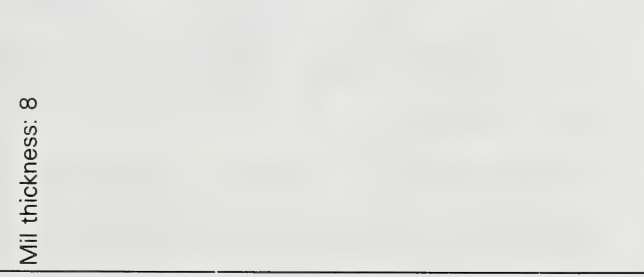 & 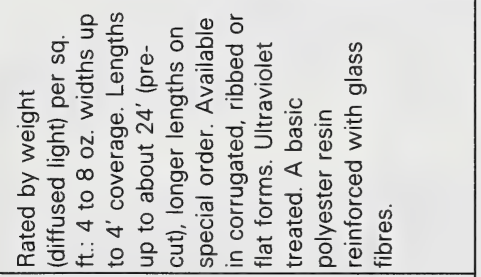 & & \\
\hline 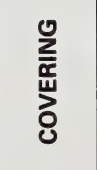 & 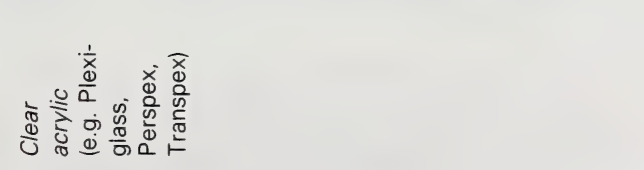 & 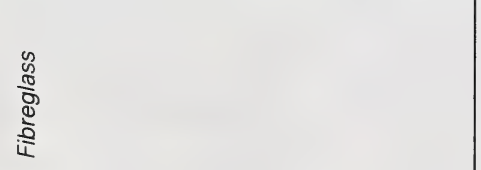 & & \\
\hline
\end{tabular}


Polyester films (Mylar, Melinex, Llumar) transmit well initially, but sunlight rapidly degrades them. Polyester is stiff and tends to tear and run when punctured. It is manufactured only in narrow widths and may not be locally available.

Acrylic laminated to polyester (Flexigard) reduces UV radiation breakdown and tearing. The acrylic side must face the outside or radiation source. This material is strong, has good light transmission and a moderately long life. At present its major limitations are stiffness, narrow width $(122 \mathrm{~cm})$ and some loss of light transmission over time.

Polyvinyl fluorides (PVF) films have become available for greenhouse glazing. They have been used for glazing flat plate solar collectors. They are ultraviolet resistant, have high transmittance, high impact resistance and high tensile strength. PVF films tear easily if punctured and are relatively expensive.

\section{Fluorocarbons. Tedlar PVF and Teflon FEP are two} fluorocarbons that have potential as greenhouse covers. They both have excellent visible light transmission and long service life with very little loss of transmission over time. Teflon has poor tear resistance and is much more expensive than Tedlar. Tedlar has excellent weatherability, is easy to clean, is relatively strong and has low long wave radiation (heat) transmission. Tedlar has been used for solar collector covers for over ten years.

Vinyl is a clear plastic film that is used in many tent style greenhouse kits, when reinforced with a polyester scrim. Vinyl is electrostatic and attracts smog and dirt, so light transmission can be rapidly reduced by surface contamination. Cleaning is difficult and may have to be done often. Vinyl lasts from two to five years and is more expensive than polyethylene of the same thickness.

\section{Glazing Management}

Light energy is often the most limiting factor for midwinter growth of many flowering and fruiting plants. Low midwinter light is due to three factors: 1 . short days, 2. low external light levels and 3. loss of light through the glazing and structure.

Loss of light through the glazing and structure is substantial. The 80 to 90 per cent light transmission values reported for various glazing materials are based on the light entering perpendicular to the surface and do not include losses due to the changing angle of the sun and to the structural framing. Light reaching the upper leaves of plants in an older glass house is usually about 65 per cent of the outdoor light level. If the glass is dirty between laps and partially covered with shading compound and the frame bars and trusses are in poor condition, the light intensity may be as low as 40 per cent of outside light levels.

Dust and soot also absorb light. In a year, light transmission may be reduced 4 per cent in a nonindustrial area and up to 50 per cent in an industrial area with heavy pollution.

Installing Glass - If you purchased a glass greenhouse kit, information on installing the glass will be found in the instruction manual. Installation generally consists of laying a bead of putty on the sash bar, inserting the glass, installing the holding clips and attaching the bar cap.

If you purchase an old wood greenhouse with the intention of rebuilding it, you must first clean the bars. A scraper, chisel or router can be used to remove the old paint and putty. Be sure to protect your eyes. Prime the bars with a coat of high quality exterior primer paint.

To install the glass, place a bead of putty on the sash bar and lay the glass in place. If you are using old glass, place warped glass with the bow up. Start at the front wall and allow the glass to extend over the sill slightly. Lap the next pane 0.6 to $1.25 \mathrm{~cm}$ over the lower one. Place one bead or point on each end of the glass to prevent it from slipping down and three on each side to hold it in place (figure 13).

When all of the glass is in place between a set of bars, trim the putty above and below to leave as little putty as possible exposed to the weather. Complete the job by painting all the woodwork and sealing the putty with paint.

Replacement patio door units also make an attractive glazing. They may be sealed with silicon caulk and held with a narrow batten strip attached by screws or nails.

\section{Installing Fibreglass Reinforced Panels -}

Corrugated fibreglass panels may be installed several ways. The corrugations on roof panels should slope down so water will run off. Sidewall panel corrugations can run either direction.

Fasten the panel with aluminum or galvanized screwshank or ring-shank nails, using fibreglass or neoprene washers. Predrill nail holes in the fibreglass about $20 \mathrm{~cm}$ apart or through the top of every third corrugation to keep water out.

Roof panels should be supported and nailed to cross supports or purlins every 0.75 to $0.9 \mathrm{~m}$ length.

Corrugated wall panels can be supported every $1.2 \mathrm{~m}$ or so. Use corrugated foam-plastic filler strips under the edge 
or ends of panels to reduce air infiltration. Flat roof panels should be supported on the sides and every 45 to $60 \mathrm{~cm}$ across the roof. Wall panels can be supported every 0.6 to 0.9 metres (figure 14 ).

Corrugated sheets should overlap 1 to 1 corrugations at the sides. Use clear, flexible sealer (generally sold by the fibreglass supplier) where panels overlap. Sometimes houses are designed to nail the sides of panels to the frame. This design is somewhat stronger and tighter than one with panels just fastened to the crossbraces. Because the frame must be carefully measured and built so nails can be driven through the top of a corrugation and into the frame, this construction method is not used often.

\section{Installing Single and Double Layer}

Polyethylene - Using the air inflation method, two polyethylene sheets are fastened to the house so the edges are sealed. A small fan forces the layers apart creating a dead air space. Polyethylene may also be fastened with 2.5 to $3.5 \mathrm{~cm}$ spacers to make a double layer with an existing cover of glass, fibreglass, acrylic or other rigid cover (figure 15).

Some people use wood spacers to hold the poly film apart, because an inflation fan costs $\$ 15$ to $\$ 20$ a year to operate.

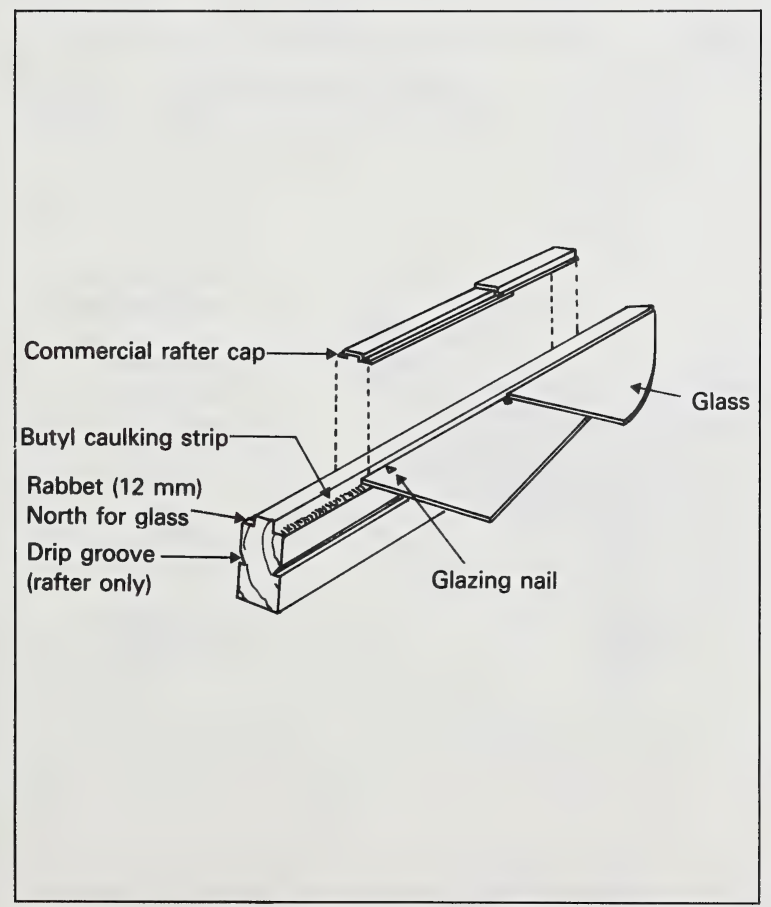

Figure 13. Installation of glass in the greenhouse

\section{FASTENERS}

7 Aluminum or zinc-coated screw-shank or ring-shank nails with fibreglass or neoprene washer attached

ANTI-DRIP SPACER

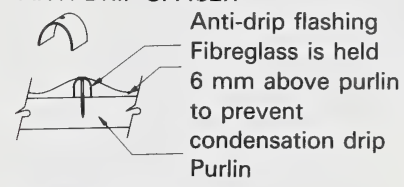

FASTENING DETAIL

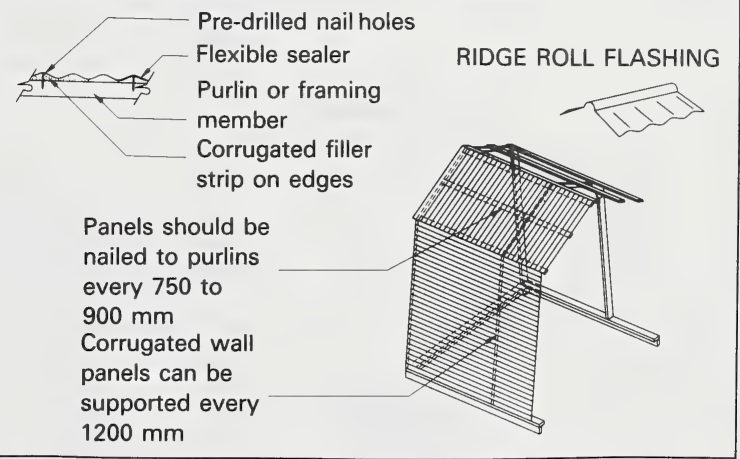

Figure 14. Fastening details for fibreglass reinforced panels

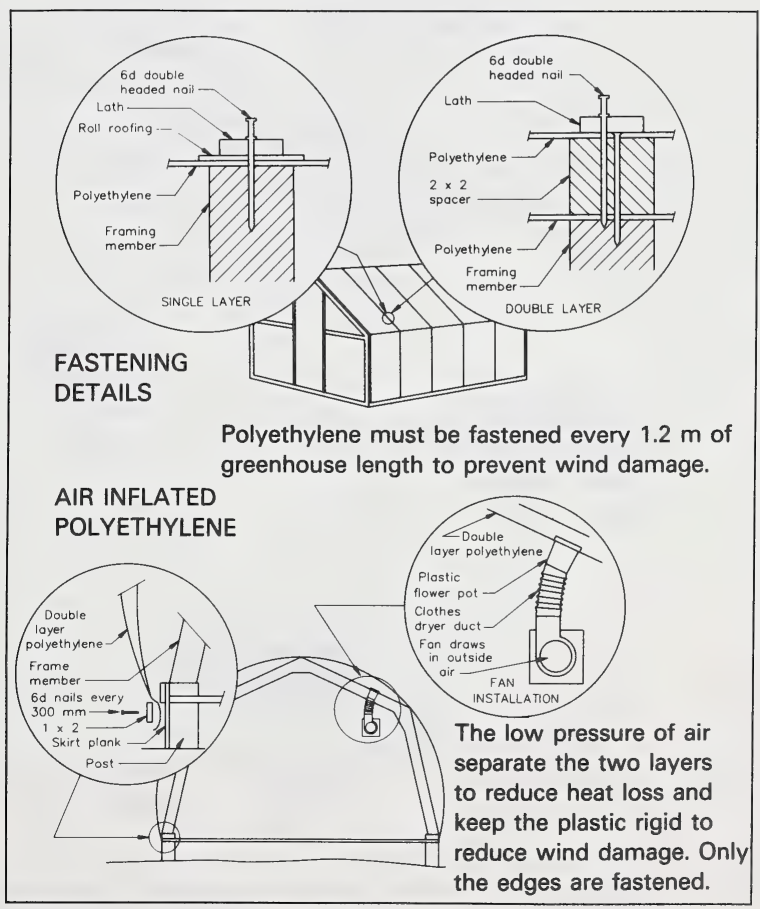

Figure 15. Installation details for polyethylene 


\section{The Greenhouse Interior}

\section{Benches}

Benches raise the plants to a convenient working height.

Plants are better handled in containers than planted directly in soil on the benches. Bench growing media need periodic pasteurizing, require heavy construction and are more difficult to manage.

Benches should be only as wide as you can reach. Side benches can be 0.6 to 1 metre wide. Centre benches that are reached from both sides may be as wide as 2 metres. Standard bench heights are 76 to $80 \mathrm{~cm}$, but they can be modified to suit your height.

A portable or hinged workbench can be lifted when not in use to let light reach plants placed under it. If the work area is stationary, there is a tendency to put plants and materials on it, and its usefulness is lost.

\section{WELDED WIRE BENCH}

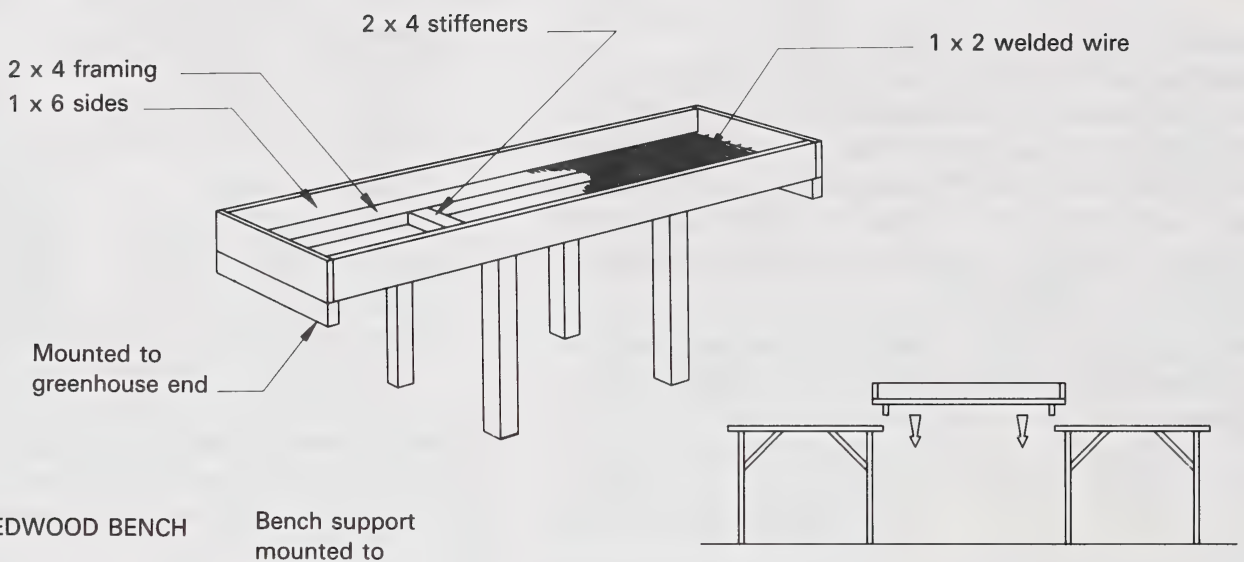

mounted to

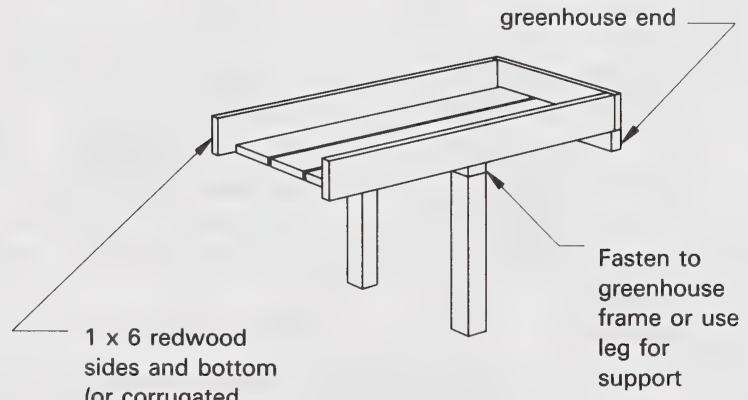
(or corrugated cement asbestos board)
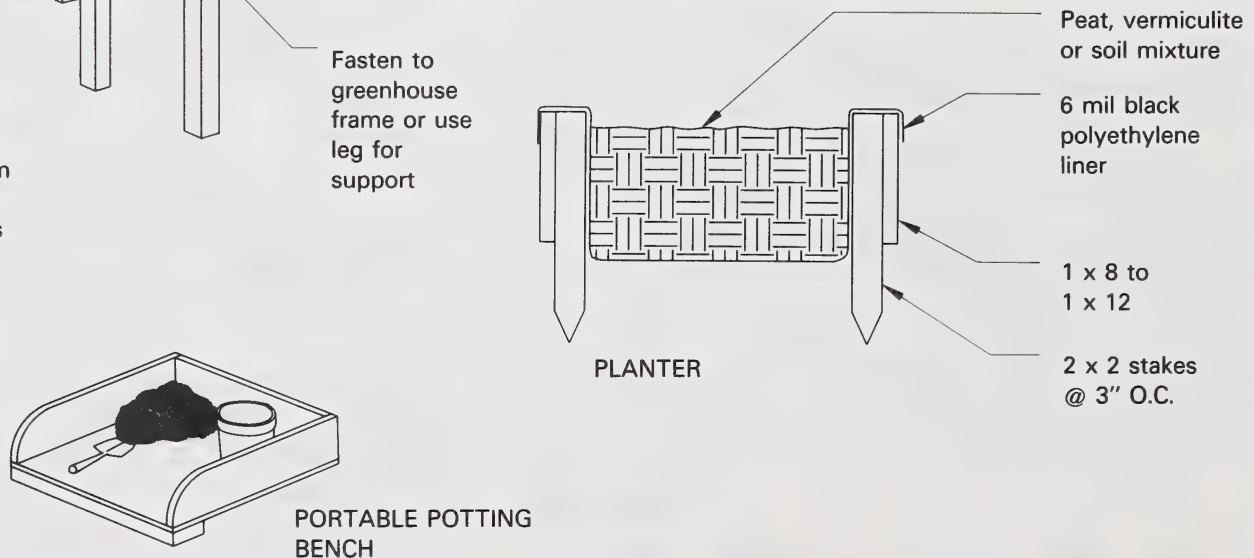

Figure 16. Benches, beds and workbenches 


\section{WOODEN STEP BENCH}

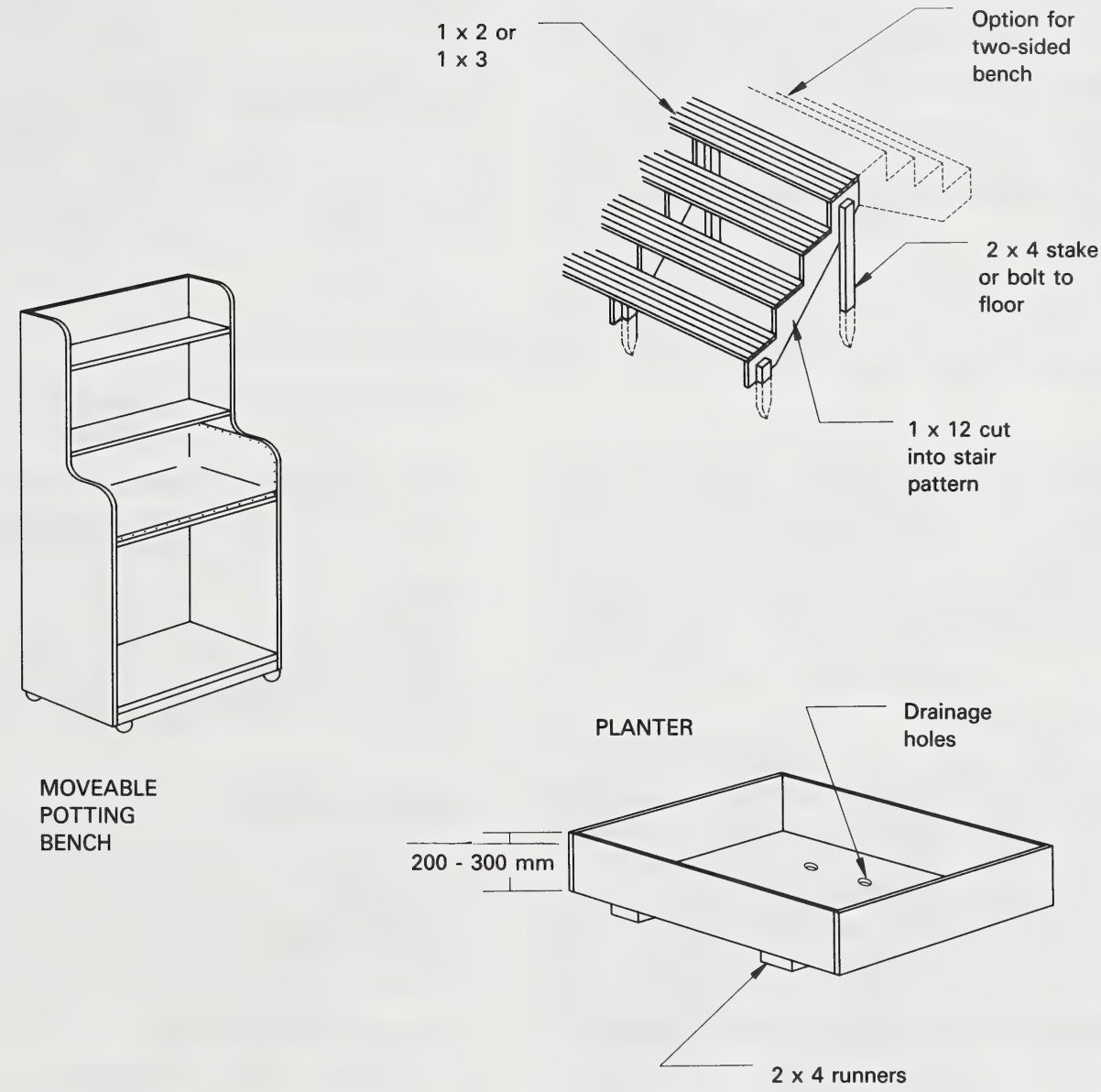

COLLAPSABLE

TABLE

Figure 16. Continued 


\section{Beds}

Growing beds can be built as movable boxes or fixed permanently to the greenhouse floor. Beds are often used along the south side to allow more sunlight to reach both the plants and storage at the rear.

A bed worked from one side should be less than 1 metre wide. A centre bed can be up to 2 metres wide. To have enough soil for good plant growth, make the bed 20 to $30 \mathrm{~cm}$ deep.

Lumber for beds and benches should be treated with a preservative to keep it from rotting. Remember not to use creosote and pentachlorophenol wood preservatives because they release vapors that are toxic to plants.

\section{Shelves}

The space above the rear benches or storage may be used to grow plants. Hanging baskets can be suspended from the ceiling or shelves can be attached to the rear wall. Preservative treated boards $(2.5 \times 30 \mathrm{~cm})$, supported by shelf brackets spaced up to 1 metre apart, work well.

\section{Storage for Supplies}

Greenhouse plants require tools, fertilizers, chemicals, containers, potting soil materials, etc. You will need to plan a storage area for all these items when you plan the greenhouse. The high humidity of the greenhouse, which is beneficial to plants, ruins tools and chemicals.

Greenhouse storage should be separate, but nearby. If the greenhouse is heated, extra space for storage in the greenhouse means more costly heating. A potting bench in the storage area is handy to mix growing media and fill pots.

\section{Flooring}

A good walking surface in a greenhouse should be one that is easy on the feet, drains well and does not get slippery. The various flooring materials are detailed in order of relative cost in table 6.
TABLE 6. Greenhouse Flooring Materials

Material Comments

Pea Gravel

Soft; difficult to walk and move wheelbarrows on.

Concrete (ready mix) Puddles may develop because of lack of porosity; can become slippery with algae.

Porous concrete**

A new non-skid, stable, quick draining material.

Wood (treated)

Gets slippery; rots unless pressure-treated and provides sites for disease organisms to grow.

Brick (on sand bed)

Porous aggregate

Attractive; gets slippery with algae and moss.

Pea gravel mixed with epoxy resin, available in range of colors; attractive; non-skid; quick draining.

Stepping stones Attractive; tendency to tilt; can get slippery.

* * To make a 1 sack batch-mix 1 sack of Portland cement well with $200 \mathrm{~kg}$ of $1 \mathrm{~cm}$ crushed rock or pea gravel and $15 \mathrm{~L}$ of water.

Pour to a depth of $7-10 \mathrm{~cm}$ and use a rake, not a shovel or trowel, to level.

\section{Maintenance}

Every greenhouse structure needs some annual maintenance. A well maintained greenhouse provides a better environment for plant growth and human comfort, protects your investment and reduces energy loss.

\section{Maintenance Checklist}

1. Are there signs of rot or decay?

- Remove and replace rotted wood.

- Paint with a wood preservative.

- Spray entire inside of greenhouse with bleach (1 part bleach to 10 parts water)

2. Does your greenhouse need repainting to protect wood and increase reflected light?

- Use a greenhouse paint, one formulated with rust inhibitors and fungicide.

3. Are any glass panes loose or broken?

- Replace or repair glass and re-putty.

4. Is the fibreglass getting old and exposing fibres?

- Clean and apply liquid acrylic resin (fibreglass refinisher).

5. Is the greenhouse covering clean for winter?

- Spray or brush apply a mild detergent and rinse thoroughly. 
6. Are there holes in the polyethylene cover?

- Mend with mylar adhesive tape (available as polymending tape).

- Replace poly if it is old.

7. Are there air leaks in the structure?

- Repair holes or cracks in the sidewalls and around doors and vents.

8. Is your heating system working as efficiently as it should?
- Summer is the best time to give your heating system a thorough check.

9. Are there weeds under the benches?

- Remove by hand.

- Spray with paraquat, but only when greenhouse is empty.

10. - Scrub and spray regularly with bleach $(90 \mathrm{ml}$ bleach per litre of water).

\section{ENVIRONMENTAL CONTROL}

\section{Heating}

(also see heat conservation techniques on p. 29)

Providing the proper temperature for plant growth is one of the most important functions of a greenhouse. A permanent heating system is needed if the greenhouse is to be operated year-round. However, if it is to be used in the spring and summer only, it is often possible to move a small space heater into the greenhouse to provide extra heat while the nights are still cold.

Fuel cost is the key issue in choosing a heating system. Select an efficient heating system that uses the most economical source of energy available in your area.

Regardless of the type of system used, the heat loss of the greenhouse has to be calculated in order to determine the size of heating unit needed. The following formula is used to determine the heat loss of a greenhouse:

$$
Q=A \times B \times C \times W
$$

$Q=$ heat loss, watts $(W)$

$A=$ The total exposed surface area of the greenhouse in square metres $(\mathrm{m})$

$B=$ The temperature differential between the coldest temperature outdoors during the period of greenhouse operation and the temperature desired inside the greenhouse $\left({ }^{\circ} \mathrm{C}\right)$

$\mathrm{C}=$ The construction heat loss factor $\left(\mathrm{W} / \mathrm{m}^{2}{ }^{\circ} \mathrm{C}\right)$ single layer poly

double layer poly

old glass

new glass

rigid plastics

$\mathrm{W}=$ The wind factor $25 \mathrm{~km} / \mathrm{h}$

$30 \mathrm{~km} / \mathrm{h}$

$45 \mathrm{~km} / \mathrm{h}$

1.25

$60 \mathrm{~km} / \mathrm{h}$
It is advisable to add $20-25$ per cent to the calculated heat loss as a 'safety factor'. Technical assistance should be obtained in planning a heating system. Sources of assistance in planning heating systems are local greenhouse equipment suppliers, manufacturers, catalogues, the local gas or electric company, and regional engineers of Alberta Agriculture who can be contacted through a district agriculturist.

\section{Hot Water Heating}

This system consists of a central heater or boiler, a circulating pump, controls and a heat exchanger in the room to be heated. Typical heat exchangers are fin-tube convection pipes or unit heaters. Black iron pipe, used in many farm buildings, is not usually practical for a greenhouse (figure 17 shows a small hot water unit heater).

Though hot water systems are one of the most effective methods for heating large greenhouses, they are not well adapted to small greenhouses, because:

1. They are very high cost systems.

2. Small-capacity boilers are not readily available.

3. Most small greenhouses do not have room for enough fin-tube convectors.

The exception is when the main residence is close and has hot water heating of adequate capacity, then it is very practical to run another hot water circuit to a unit heater in the greenhouse. If using hot water heating, select a heat distribution system in which the heat loss of the greenhouse corresponds to the heat output of the boiler or hot water heater. This requires competent design advice from an engineer or hot water system contractor. Heat output data for the heat exchanger, size of the heat exchanger, circulating pump capacity, expansion tank, valves, couplers, controls and installation details all have to be considered. 


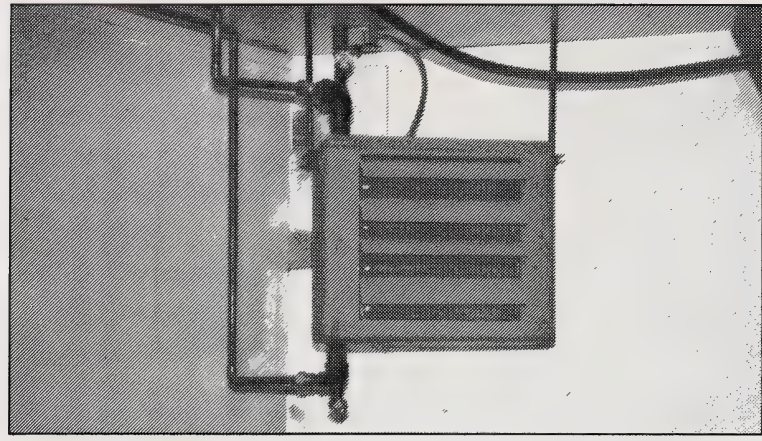

Figure 17. A small hot water unit heater

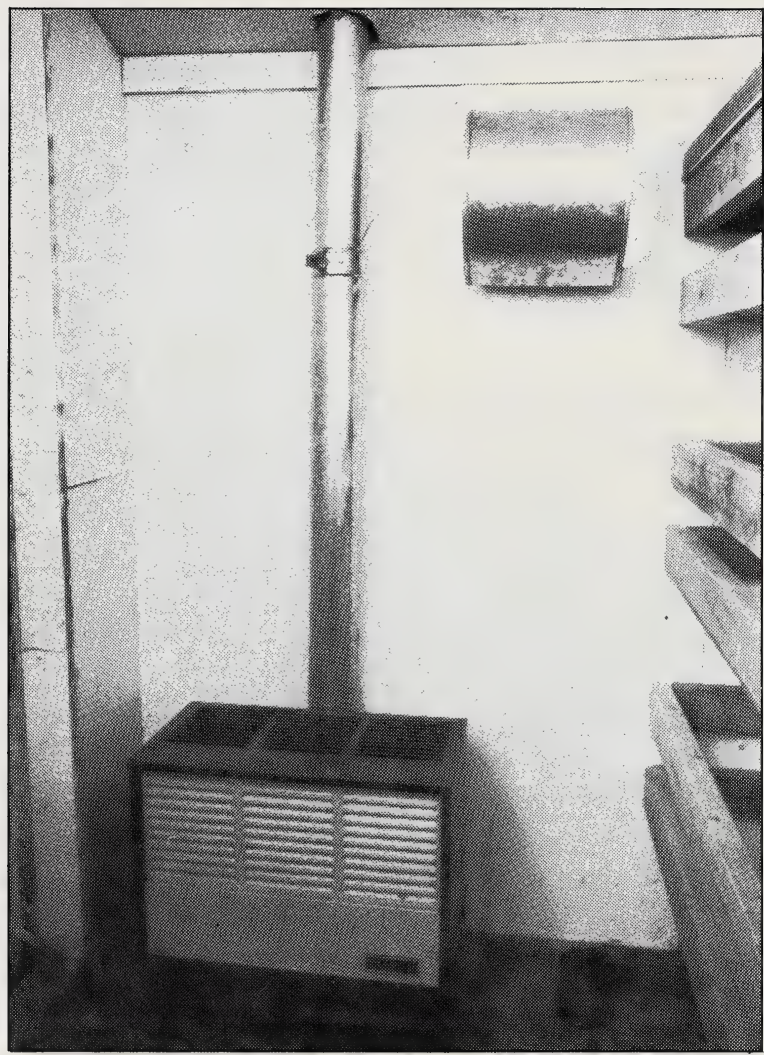

Figure 18. A small oil- or gas-fired space heater

\section{Gas and Oil Space Heaters}

Small oil- or gas-fired space heaters in the 5 to $20 \mathrm{~kW}$ range are ideal for heating a small greenhouse. (See figure 18) They are inexpensive, economical to operate and easy to control. A circulating fan hung over or behind the heater improves air circulation and heat distribution.

Do not place plants directly in the forced draft of warm air. Whenever possible, locate the thermostat far enough away from the heating unit to correctly gauge the temperature.

Gas or oil heaters must be vented by an approved flue. Gas, propane or oil heaters are of similar efficiency, so select on the basis of what is most economical for your location. This type of heater has the added advantage of not being fully dependent on power. This may be important since a small greenhouse will cool rapidly in the event of a power failure.

\section{Kerosene Heaters}

For very small greenhouses or lean-to's or for structures that require only a small amount of heat to keep frost out, small heaters that do not require a chimney are satisfactory and fairly economical to operate. These heaters produce a certain quantity of fumes to which some plants are sensitive (e.g., cucumber, tomatoes, fuchsias, and roses).

\section{Electric Heaters}

Electricity, although it is convenient, is too expensive for heating. It can best be used in small, well built greenhouses. Even with a very small greenhouse, insulation, in the form of plastic stapled to the inside of the sashbars, should be used to cut down the heat loss. Electric heat supplied by soil-heating cables is the best way of providing bottom heat for a small propagating bed within the greenhouse.

\section{Solar Heat}

The sun is another source of heat that can be used in greenhouses.

\section{Heating Attached Greenhouses}

Three options are available for heating the attached greenhouse:

- Open the greenhouse/sunpace to the remainder of the house.

- Install separate heating appliances in the greenhouse.

- Circulate house air through the greenhouse.

The attached greenhouse can not be effectively heated by running ducts from the typical household furnace to the greenhouse. During the day when the greenhouse has excess solar heat, the home furnace will still operate, supplying heat unnecessarily. At night, when the greenhouse requires quite a lot of heat, the furnace (with an in-home thermostat) will not operate often enough. (Or, if it did supply enough heat, the home would become overheated.) 
Opening the greenhouse/sunspace to the rest of the house is simple and effective. Larger patio doors or screens should be opened or closed as required. This system may not be convenient, requiring attention for a few minutes several times a day. Effectiveness depends a lot on the size and orientation of the greenhouse; generally better for smaller greenhouse.

Separate heating units such as gas heaters or hot water radiators are better for most attached greenhouses. These units provide the temperature control where it is needed, when it is need.

Recirculating systems are most effective (figure 19 and 20). They redistribute excess heat collected by the greenhouse on sunny days to supplement home heating. Recirculation is provided by a fan (furnace fan) and a duct system. Filters on the return air are required for filtering out contaminants like aphids, white flies or pollen. This system can be relatively expensive if the greenhouse air is distributed throughout the house instead of being dumped into the basement.

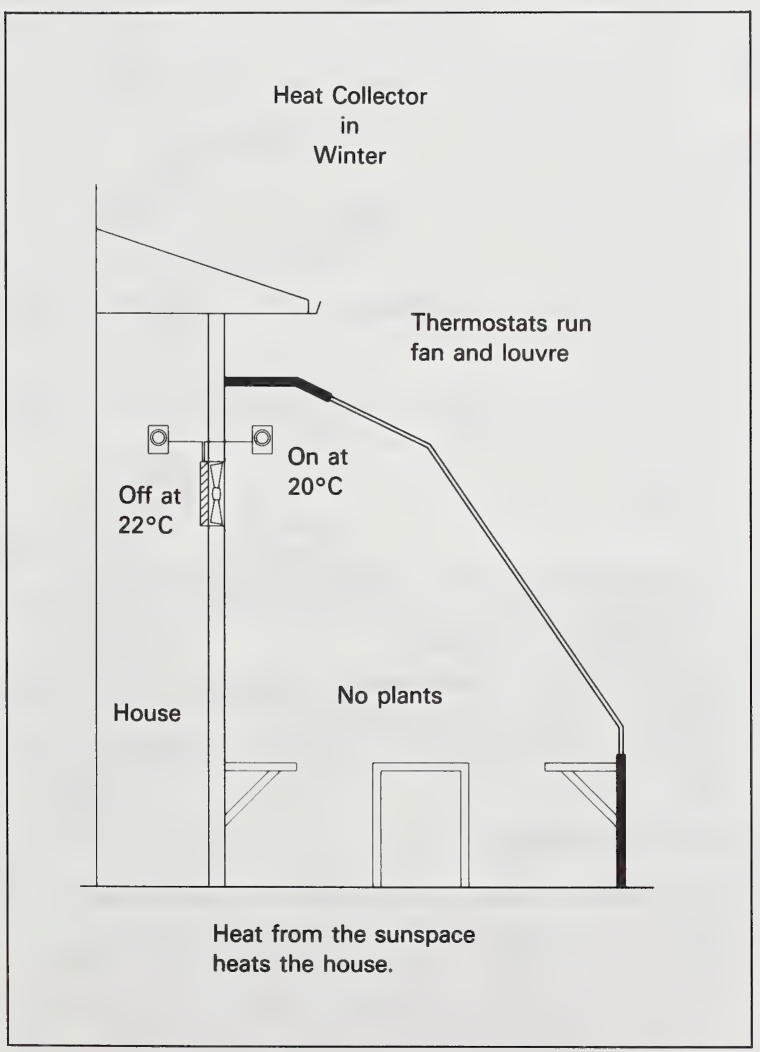

Figure 19. Heat recirculating system

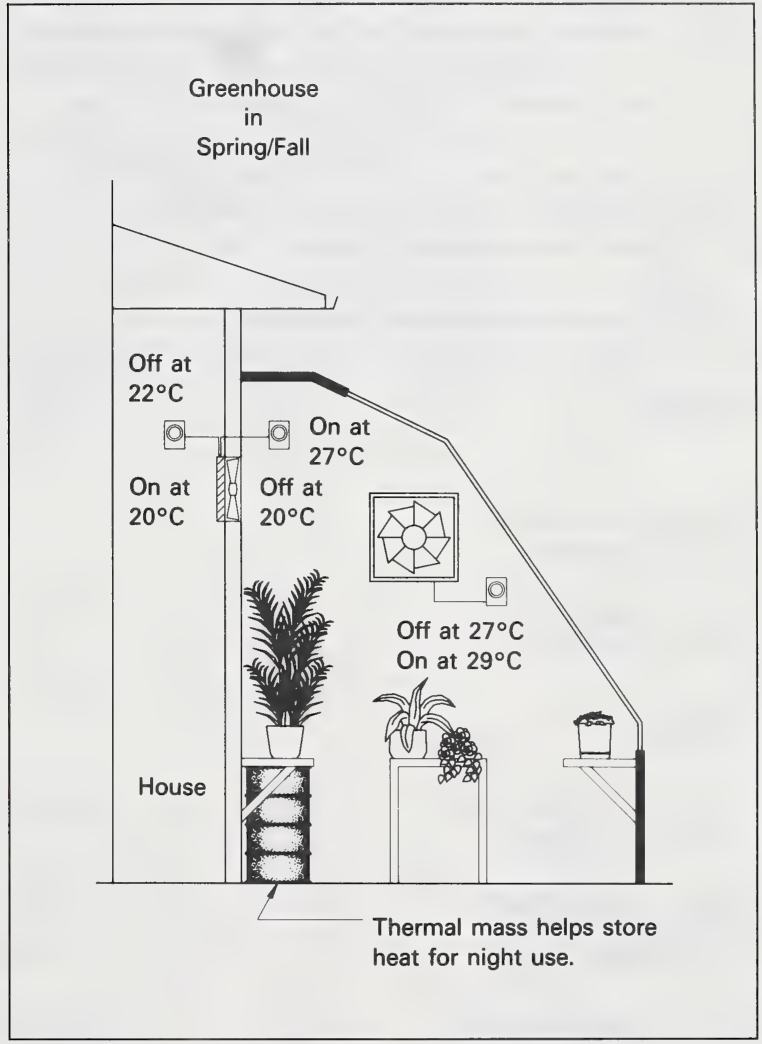

Figure 20. Heating an attached greenhouse from the house

1. Fan blows warm air from house into the greenhouse.

2. Air returns by screen door or vent into the house

3. Fan draws excess heat from greenhouse during daytime heating, blowing it into the house (preferably the basement). If the house does not require heat, this fan can be diverted outdoors.

4. Greenhouse supply air can be from outdoor vents, or from inside the residence during cold weather.

5. Removable filters

\section{Energy Conservation}

The largest heat loss from a greenhouse occurs from the glazed area. Double glazing will reduce heat loss by at least 30 per cent because the space between layers reduces heat flow. On the other hand each additional layer of glazing reduces the amount of solar energy entering the greenhouse by 5 to 15 per cent.

For many greenhouses a single glazing and a movable insulating blanket work best to allow maximum light during the day and good insulation at night. 


\section{Movable Blankets or Shutters}

These night time insulation barriers can be very effective. The key to their effectiveness is not so much the material that is used; instead, it depends on how faithfully you open and close it. Often the insulation is not closed as soon as the sun starts to set. A properly installed and operated blanket or shutter can reduce heat loss 25-40 per cent over an uninsulated system.
Table 7 reviews the more common blanket materials used. Most materials are supplied in rolls and must be fabricated to the proper size. Some manufacturers and suppliers have facilities to do the fabrication. The material should be flame-resistant, tear-resistant and easy to work with. It is also important that a tight seal be formed around the edges to reduce heat loss.

TABLE 7-Greenhouse Blanket Materials.

\begin{tabular}{|c|c|c|c|c|}
\hline Materials & $\begin{array}{l}\text { Cost/ } \\
\text { sq. m } \\
\text { (\$) }\end{array}$ & $\begin{array}{l}\text { Avg. } \\
\text { Life } \\
\text { (years) }\end{array}$ & $\begin{array}{c}\text { Heat } \\
\text { Trans- } \\
\text { mission'1 }\end{array}$ & $\begin{array}{c}\text { Heat Loss } \\
\text { Reduction } \\
(\%)\end{array}$ \\
\hline
\end{tabular}

Black polyethylene film

(6 mil thickness)

Clear Polyethylene film

(6 mil thickness)

Aluminized fabric

(Foylon)

PVC laminate (Ultrafilm) Al/Temp, Al/Black

Spun bonded polyester (K shade, Tobacco

netting, Remay)

Foam backed, fiberglass drapery material

Woven and lofted

Polyester (Thermoshade, Thermoskreen)
1.10

1.10

$1.10-2.16$

$1.10-2.16$

$1.10-2.16$

5-10

High

38

2.16

$1.10-2.16$

10

Medium

50

Source: Based on research at Pennsylvania State University and Rutgers University.

${ }^{1}$ Based on tests in a glass greenhouse.

${ }^{2}$ Approximate night time heat reduction in a glass greenhouse.

Before selecting an interior insulating system consider the following:

1. It should block very little or no light when it is in the stored position. It is best stored against one of the insulated walls.

2. It should not interfere with the plants when it is being extended or withdrawn. The benches or beds should be kept 10 to $20 \mathrm{~cm}$ from the wall.

3. A one piece thermal blanket is better than several smaller ones because it will have fewer cracks. The effectiveness of the blanket will depend on how tight the edges seal in heat.

4. The insulation should be withdrawn every day. It should be left open on nights when heavy snow is expected, so snow will melt and not overload the greenhouse. Supplemental heat should also be used to help melt the snow.

5. The insulation should resist flames, tears and mildew, as well as be easy to repair.

6. The heat source should be inside the blanketed area.

\section{Pop-in Shutters}

Foam insulation board can be cut to fit between wall studs and ceiling rafters. This insulation system is relatively inexpensive to build and is more effective than thin blanket materials if installed properly. Polyurethane, extended polystyrene and isocyanurate are the best materials for this application. They can be easily fitted to 
irregular shapes, and they do not absorb moisture. These insulators are also available with an aluminum foil facing that increases the insulation effect and provides some mechanical protection.

When building these units cut the pieces to fit snugly between the frame members. Edges can be covered with duct tape to keep them from breaking. Nail $1.2 \mathrm{~cm}$ wide spacers to the framing to keep a space between the insulation and the glazing. Wood turn knobs or magnetic clips will hold the panels in place. Roof and wall panels may be made to slide into place.

Shutters take longer to close than blankets as each piece must be handled individually. They also require storage space during the day such as a rack in one corner, under the benches or against fixed endwall panels.

\section{Track-supported Blanket}

This insulating method uses a flexible, thin material supported by tracks and rollers or slides. During the day the material is stored folded against a back or endwall. At night it is extended to cover the glazed area. Many commercial greenhouses use this system because it is easy to install and operate. The materials are available from most greenhouse equipment suppliers (figures $21 \& 22$ ).
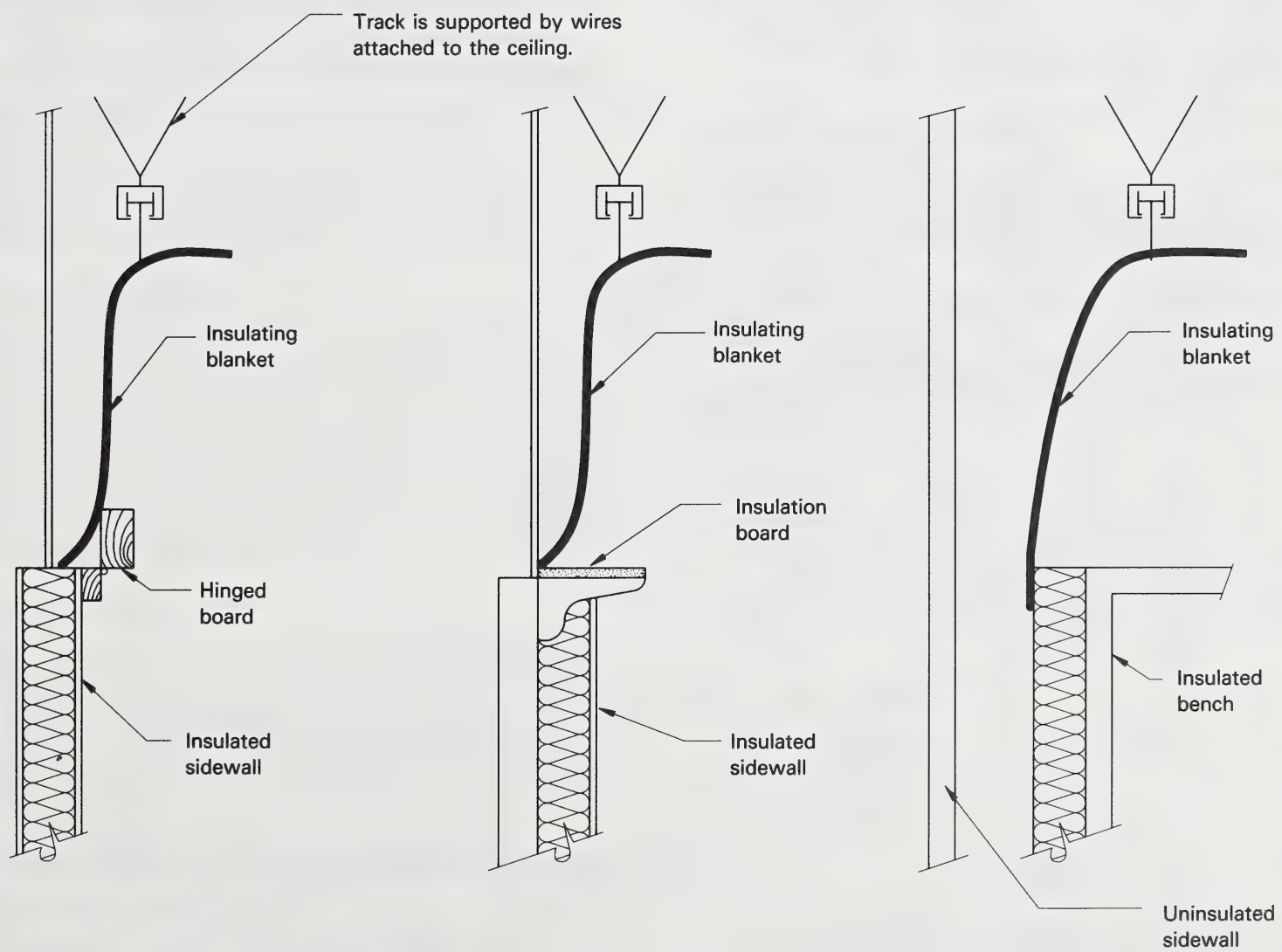

Figure 21. Track supported blanket system 


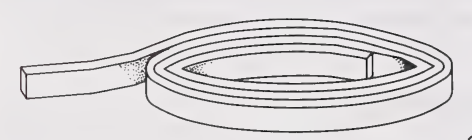

Reduce air leaks, patch holes and weatherstrip doors.

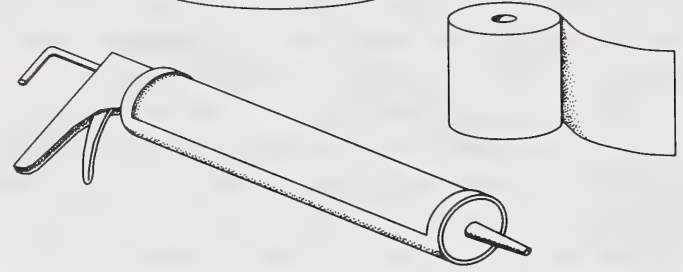

Figure 22. Edge sealants for track supported blankets

\section{Blanket Installation}

1. Layout the system so that it will store in a convenient location. Track sections should be spaced no further than 2.5 metres apart. Provide space for the curtain to clear plants and benches.
2. Attach track to the framework or support it with wires. The track can be bent slightly to follow roof contour. Track sections should remain parallel and level with each other. Insert the rollers before closing ends of the track.

3. Fabricate the blanket if this has not been done by the manufacturer. Allow extra material for seams, a slight sag and extra material at sides for seal. The leading edge should have a stiffener (conduit or pipe) either sewn in or attached to it in order to allow uniform movement of the blankets.

Locate gromments, tabs or hooks carefully so that the blanket will hang and close evenly. Remember that the spacing of the supports should be twice the distance that you want the fold to hang ( 1 metre spacing of support 0.5 metre fold).

4. Make provisions for sealing the sides. This can be $2.5 \times 10 \mathrm{~cm}$ hinged boards or $\mathrm{V}$ shaped heat trap.

5. For ease of operation, install a cable-pulley system to open and close the blanket. A blanket in a small greenhouse with a horizontal track can be manually

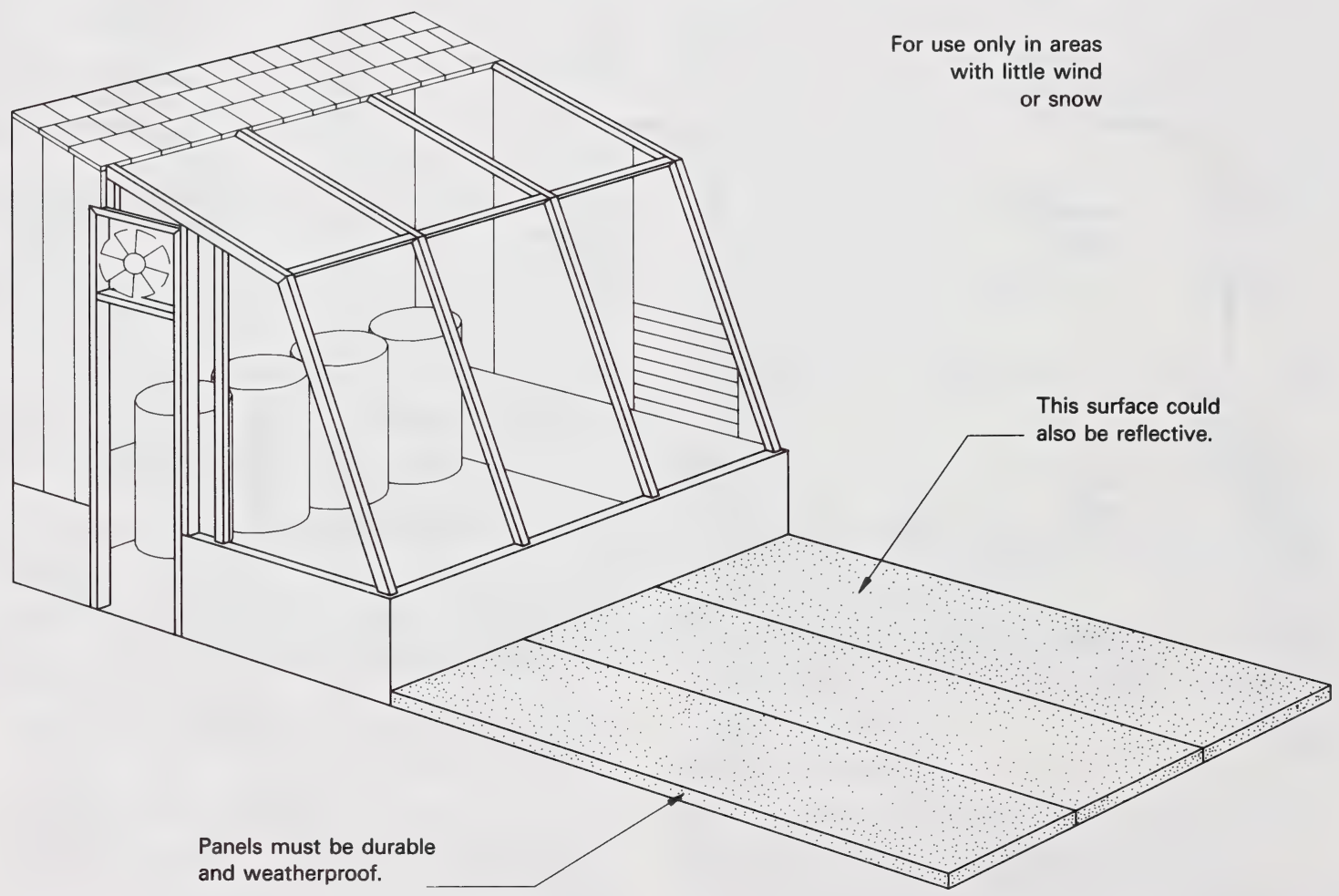

Figure 23. Exterior insulation system 
opened and closed. When the track runs on an angle a system of pulleys and clothes line can be used to retract the blanket to its storage position.

\section{Roll-up Blankets}

An alternate method of installing a blanket, especially with sloping or vertical glazing, is to roll the blanket similar to a roll-up window shade. Both thin films and thicker insulating blankets can be handled with this method. Of course, the thicker the material, the larger the diameter of the roll will become and the greater the amount of space that will be needed for storage.

The blanket is fabricated to fit the size of the glazed area. One end is permanently attached to the frame at the top of the glazing. The other end is fitted with a weight similiar to that used in the track supported method. On vertically glazed areas the blanket must be supported by wires or cables attached at both the ridge and eave and located several centimetres below the glazing.

The gaps at the edge of the blanket can be closed with hinged boards or magnetic tape. One such tape (Plastiform), manufactured by 3M Company, has an adhesive backing. One piece has to be placed on the blanket and a second piece placed on the greenhouse frame located where it will match the first piece.

\section{Exterior Insulation}

Lack of space, the design of greenhouse or bench layout may rule out the use of an internal insulation system. Exterior insulation systems can be used as an alternative. They work well when designed and fabricated so they are easy to operate and fit tightly when closed. Generally exterior units are more expensive to build because they must be weather resistant. Sleet and snow are especially troublesome to remove (figure 23).

\section{Vapor Barriers}

The warm, humid greenhouse can rapidly wet fibreglass and cellulose insulation and cause them to lose their insulation value. Prevent this moisture movement by placing $4 \mathrm{mil}$ (.004 inch) or thicker polyethylene film between the greenhouse and the insulation to create a vapor barrier.

\section{Other Energy Conserving Measures}

\section{Reduce Air Leaks}

- Keep doors closed-use a door closer or spring.

- Weatherstrip the doors, vents and fan openings.

- Lubricate louvers frequently, so they close tightly. A partially open louver dramatically increases heat losses.

- Repair broken glass and holes in the plastic covering

- Close holes under the foundation of plastic covered houses.

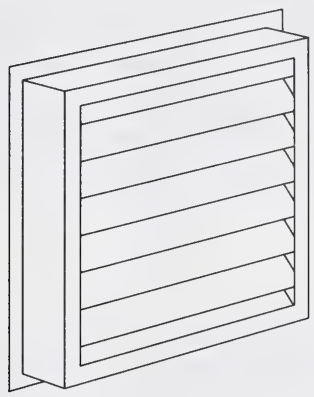

Lubricate louvres frequently so they close tightly.

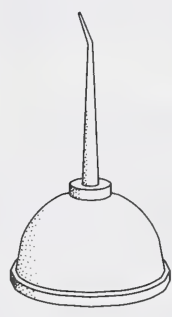

Figure 24. Lubricate louvres

\section{Efficient Heating Equipment}

- Thermostats should be correct to within one degree, check them with an accurate thermometer. Use a small fan to blow air across the thermostat for more uniform control.

- Have the heating system checked to make sure it operates at peak efficiency.

- Clean heating surfaces often.

- Insulate distribution pipes and ducts in areas where heat is not required.

\section{Water}

- Insulate hot water pipes to reduce heat loss.

- Eliminate all water leaks. A faucet dripping 60 drops per minute will waste 300 litres of water per month. If this is hot water, it will cost 70 cents per month to heat it.

\section{Winter Shut Down}

- Cover unused fans, vents, etc. in winter.

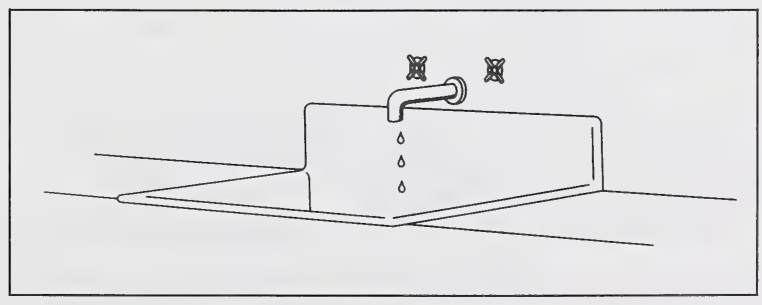

Figure 25. Eliminate water leaks 


\section{Emergency Heating}

Unlike other buildings, a greenhouse cools very quickly at night if the heat is shut off. Since many of the plants grown in a geenhouse demand certain temperature levels, a heating failure could be disastrous. To lessen the danger of losing plants, consider installing an alarm system to warn you if the heaters fail. It is equally important that you be prepared to hook up an adequate back-up system to hold back the chill until the main heating system can be restored. Auxiliary heat can be generated by a portable electric heater or a keroseneburning unit.

\section{Ventilation}

Ventilation is necessary for removing excess heat and humidity, providing air circulation, and replenishing the supply of carbon dioxide for the plants. It is a commom mistake to underestimate greenhouse ventilation requirements. A greenhouse must be ventilated yearround. During cold bright weather, a small amount of ventilation is more difficult to produce in plastic-covered houses than in glass-covered ones.

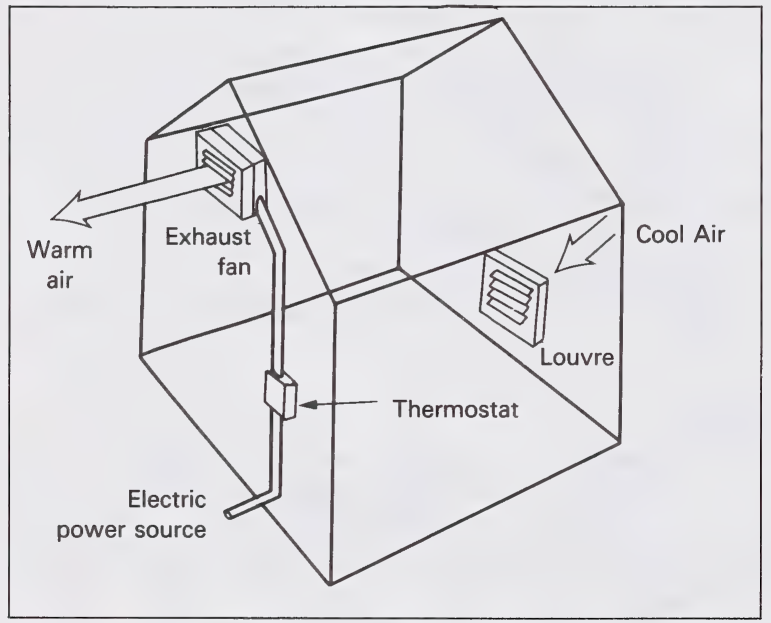

Figure 26. Ventilation by fans

There are two main methods of ventilating your greenhouse: one is with a system of vents, the other by means of fan. These systems may also be used in combination for more efficency.

With the vent system, window-like openings (vents) are usually placed on the greenhouse roof at the ridge line. Secondary vents are placed near the base of the greenhouse, either under or over the benches (see figure 26).

Ridge vents usually come with a notched handle and a prop, or a lever with a gearwheel to allow manual opening. By opening these vents, a warm-cool air exchange is established which provides fresh air for the plants. This air exchange creates air movement within the greenhouse, providing needed circulation. Since direct sunlight heats a small greenhouse rapidly, a small house should have proportionally more ventilators than a large house. Ventilation systems are included in most greenhouse plans.

A ridge vent system can be operated automatically by motor-run lifters triggered by a thermostat set at a desired temperature. Another automatic vent opener, called a heat motor, works without electricity or wiring. It consists of a tube filled with liquid that expands as the air temperature increases and contracts as it drops. The expanding liquid pushes a rod, and the rod opens the vent. With a dial, the device can be set at the temperature level at which you want the vent to start opening (figure 27).

One advantage of automatic ventilators is that they keep the greenhouse from overheating during the day, then they close when the greenhouse begins to cool off in the evening, trapping the remaining absorbed heat for the night.

A fan system is another method of providing ventilation. (see figure 26.) To be adequate, the fan(s) must exchange the total volume of air in the greenhouse 1.5-2 times per minute. Since fans are rated according to the volume of air they exchange per minute, determine fan size by calculating the greenhouse volume (cubic metres), and multiply by 1.5-2.0. The answer in cubic metres per minute is the fan capacity that will be needed. Two-speed or variable speed fans are preferred over one-speed fans. If possible, fans should be located in an end wall, drawing air down the long axis of the greenhouse.

The exhaust fan system, similar in principle to a kitchen exhaust fan, draws out the heated air. Exhaust fans are installed high, near the roof line and above plant level, to prevent drafts. A thermostat turns the exhaust fan on when a pre-set temperature is reached. A second vent-a louvered shutter-has movable horizontal flaps. When the exhaust fan starts, the flaps swing open because of the air pressure differential and cool air enters. This second vent is placed at a lower level, frequently below the benches. The cool air moving across the greenhouse mixes with the warmer air.

An intake fan system works on the same principle, but in reverse. Fresh, cool air is brought into the greenhouse, and by changing the air pressure inside, forces the warm air out through a louvered shutter or roof vents. Both fan systems work equally well, and both require electricity to operate. 


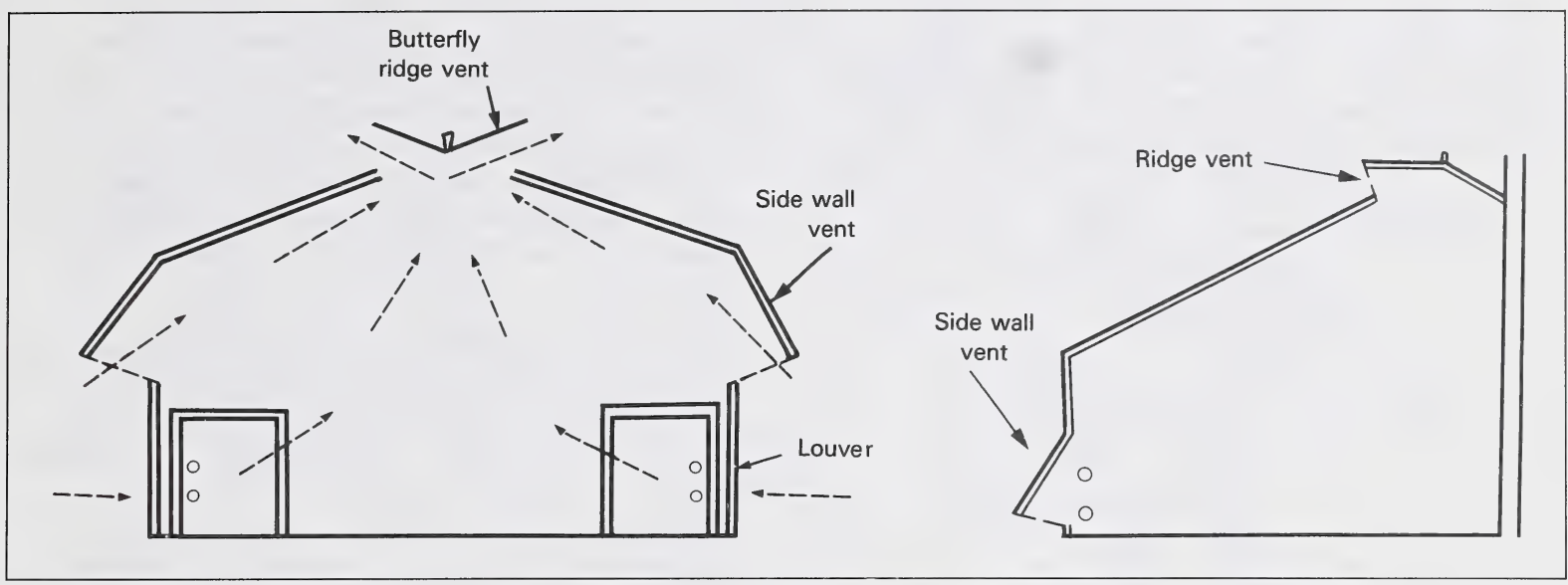

Figure 27. Ventilation by ridge and side vents

Fans are also desirable for air circulation within the greenhouse, particularly when ventilation is minimal. They should be angled so they won't create drafts or too much air turbulence.

\section{Cooling}

Under Alberta summer conditions, especially June and July, greenhouse temperatures may rise above $30^{\circ} \mathrm{C}$; therefore, cooling is required in addition to ventilation for growing some types of plants. The commonly used systems in Alberta are evaporating coolers or mist blowers.

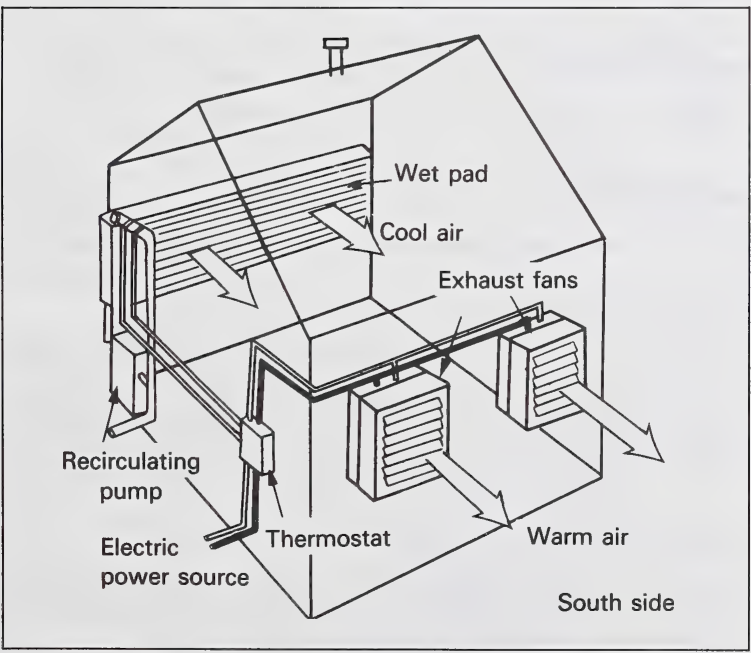

Figure 28. Pad and fan cooling systems

Evaporative coolers, usually called "swamp coolers" require electricity to operate. A fan, activated by a thermostat, pulls air into the greenhouse through aspen fibre pads which are kept wet by water dripping from an overhead trough. Air moving through the water-soaked pad is cooled as it absorbs some of the moisture. Not only does the evaporative cooling system cool the greenhouse-it also provides some humidity. The pad and fan system can be purchased as separate components and mounted on opposite sides of the greenhouse (see figure 28), or as an integrated unit called an "Arctic Cooler" (figure 29). The aspen fibre pads must be washed down regularly to keep them from becoming clogged.

If you plan to install separate pad and fan components, it is easy to determine the correct capacity needed. As described in the section on ventilation, determine the fan size needed to provide two air exchanges per minute. One square metre of pad will be needed for each 50 cubic metres per minute of fan capacity. Use $0.5 \mathrm{~L}$ water/min per lineal metre of pad, regardless of pad height.

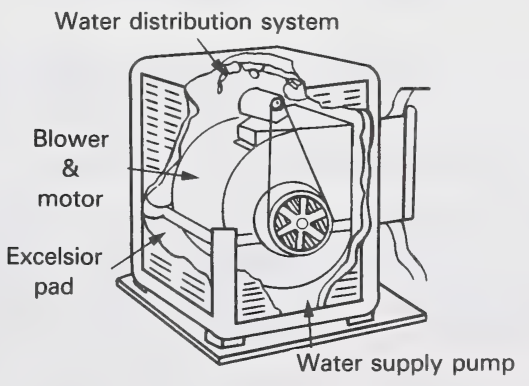

Figure 29. Arctic cooler 
Mist blowers also use fans as part of a system that is activated by a humidistat, a device that measures moisture in the air. The fan blows mist from a fine jet of water into the greenhouse. The mist cools the air and also provides needed humidity (see figure 30 ).

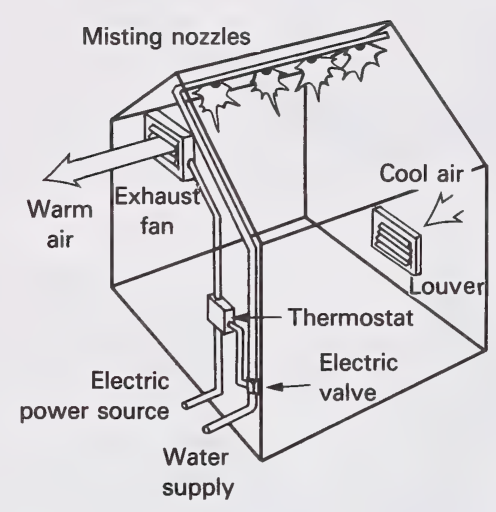

Figure 30. Mist-cooling system

Manually operated systems can also be used, but they are dependent upon your presence. You can mist your plants with a hose and a mist nozzle and wet down benches and floors to cool these surfaces through evaporation.

\section{Humidity}

Adequate moisture levels in your greenhouse are necessary for good plant growth. Generally, humidity levels of $50-75$ per cent are required. When plants transpire, they give off moisture through their leaves. To replace this moisture, they need adequate moisture around their roots and in the air. If humidity levels are low, plants will transpire more rapidly, causing them to wilt if water around the roots is not adequate. During the day, the air inside the greenhouse warms up and this heat reduces the relative humidity. To keep the moisture level high, you will have to introduce water into the air (increase humidity).

Evaporative cooling systems and the mist blowers provide humidity, as well as cool the greenhouse. If you do not have an evaporative cooler, consider wetting down the floor of the greenhouse at regular intervals.

As the greenhouse cools down in the evening, humidity may increase to the point where it is best to increase ventilation slightly. High humidity overnight can increase the potential for disease problems.

\section{Shading}

Shading of greenhouses is necessary for several reasons: to protect plants from the direct rays of the hot summer sun, to reduce light intensity (light levels during the summer are greater than many plants can utilize) and to help keep the greenhouse cool. Shading is often needed from June to August. Glass houses frequently need shading more than houses covered in rigid or film plastics. Many satisfactory methods exist to provide the needed shade, but some will require more maintenance than others.

Whitewashing the greenhouse is perhaps the most widely used method of providing shade. Sometime during May, a white paint-like solution is sprayed or brushed on the exterior of the glass parts of the greenhouse. The solution can be a commercial white wash made for use on greenhouses, a white, cold-water paint or a mixture of 1 $\mathrm{kg}$ of flour in $15 \mathrm{~L}$ of water. Some growers use their chemical sprayers to apply it. Be sure you completely clean out the sprayer, both before and after using it for this purpose. Whatever type of whitewash you use, it will gradually wear off, as a result of rain and watering. If it hasn't all washed off by mid-October, scrape or scrub off any remaining paint. Sometimes a good frost will remove it for you.

Besides whitewashing, several external or internal structures can provide shade: blinds made of wood strips, bamboo or aluminium slats: panels made of lath strips attached to the greenhouse; shade cloth or saran cloth. Saran cloth is made from green or black plastic, and comes in a variety of meshes, each providing a different degree of shade (see figure 31 ).

Sometimes partial shading is required for only a few plants. The best method is to stretch pieces of shade cloth only over the plants that require shade.

\section{Lighting}

Light is essential for plant life. It has a great influence on germination, growth rate, leaf size, chlorophyll production, bulb and tuber formation, and flower and seed production. At times, especially during the winter months, natural light may need to be supplemented with artificial light. The quality, intensity and duration (length of daily light period) are important in regulating plant growth.

\section{Light Quality}

Plants primarily utilize the red and blue portions of white visible light. Light in the red/orange area affects germination, maturation, and flower and seed production. It is extremely important for flowering plants. If red light is used alone, plants develop rather tall and spindly with weak flowers. 


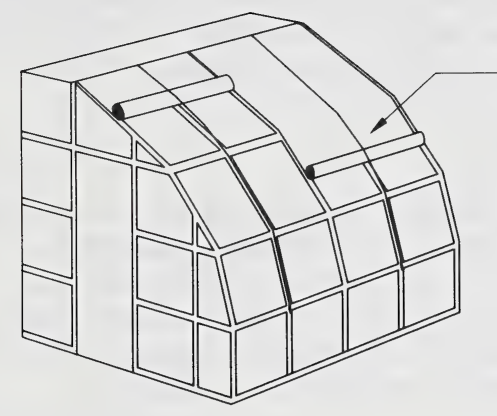

Adjustable

Exterior

Shade
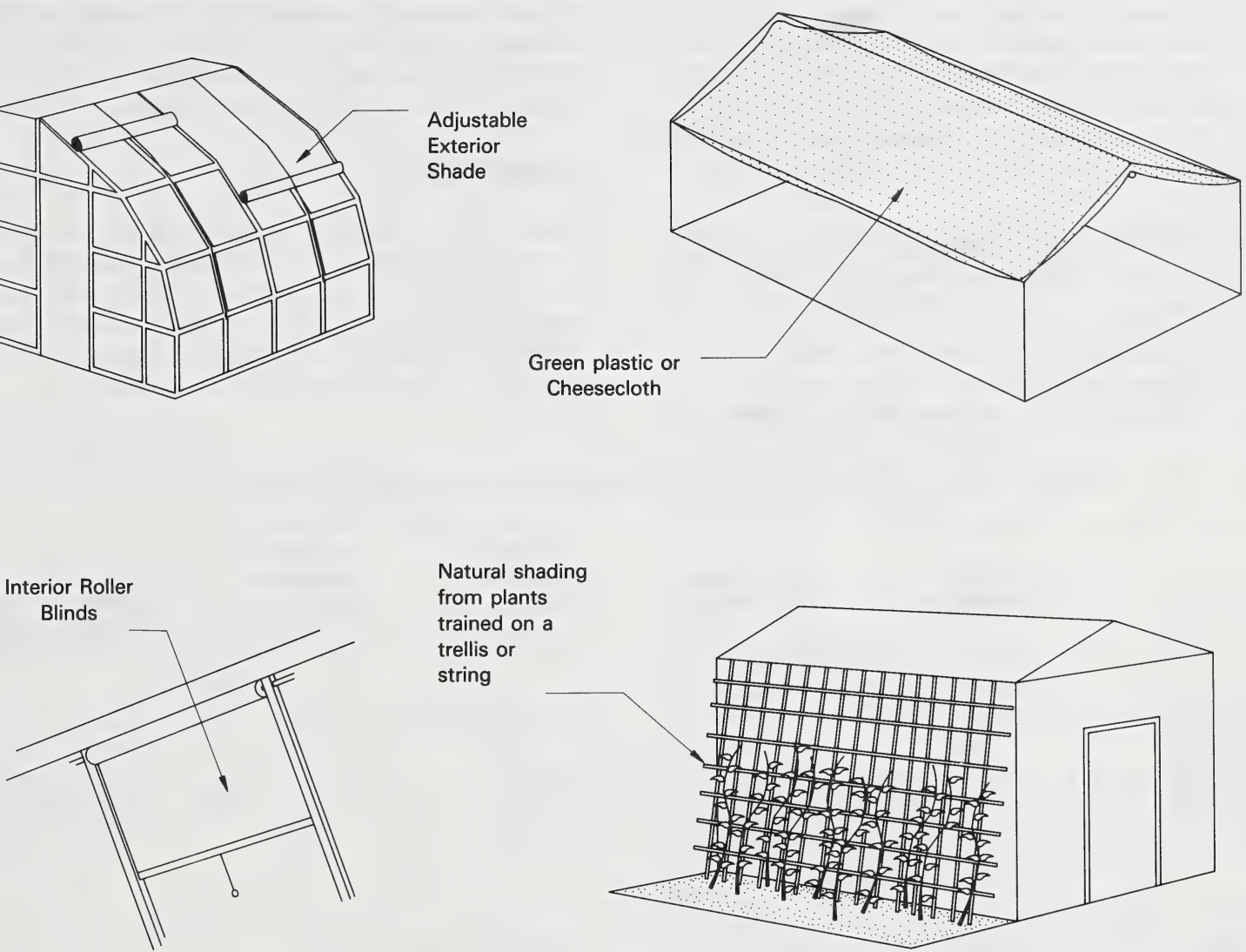

Natural shading

from plants

trained on a

trellis or

string

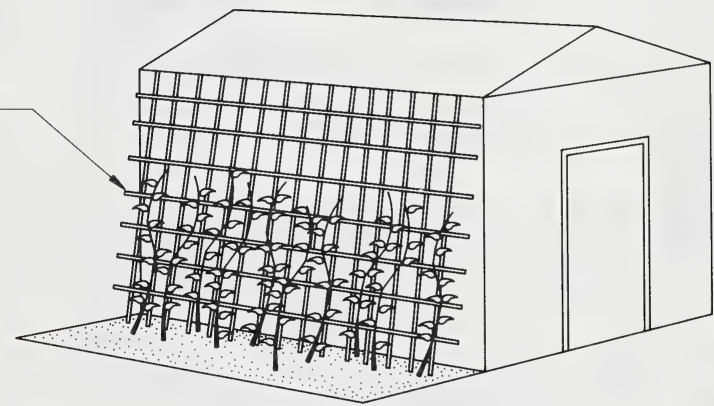

Figure 31. Summer shading devices

Light in the blue/violet area stimulates the plant to grow towards the light (phototropism) and affects leaf development. Plants grown under blue light tend to be short and stocky with thick stems, dark green leaves and few flowers.

\section{Light Intensity}

Every plant has its own requirement for light; some demand very bright light and some are shade lovers. If a plant receives too much light, it will grow extremely compact and the leaves may curl under. The tender tissues may also burn and the tips of the leaves turn brown. If a plant receives too little light, however, it will grow tall and spindly and will not flower.

Light intensity (illumination) is often measured in lux (lx) or kilolux (klx), even though there are more accurate ways to measure light for plant growth. "It is important to become familiar with the term lux if you plan to introduce artificial light. The natural light level on a bright clear day in summer can reach $100 \mathrm{klx}$. Most sun-loving plants prefer light intensities of 10 to $50 \mathrm{klx}$, whereas shadeloving plants thrive with 1 to $5 \mathrm{klx}$. Moderately priced incident light meters are available to measure light intensity.

* The imperial system equivalent is footcandle:

1 footcandle $=10.7$ lux.

\section{Light Duration}

The response of a plant to the length of the light and dark periods is known as photoperiodism. Photoperiodic response can vary: leaf growth instead of seed formation in lettuce, bulb formation instead of leaf and stem growth in onions, and the flowering of chrysanthemums are all associated with length of exposure to light. 
The majority of plants fall into one of three categories: short-day, long-day and day-neutral plants. Short-day plants undergo a response when the day length is less than 12 hours, e.g., flowering of chrysanthemum. Longday plants respond when the day lengths exceed 12 hours, e.g., flowering of many annuals. Day-neutral plants do not respond to the variations in the light-dark cycle, e.g., flowering of roses.

This response to day length means you will have to carefully structure the light environment in your greenhouse if you want certain plants to flower.

To provide short days when natural day length is long, shield the plants from light by shrouding them with opaque black cloth supported on a frame. The cloth must be completely opaque since even a very small amount of light will destroy the long night effect. Darken the plants and remove the covering at the same time each day. When natural day length is short, one or two lights turned on at sunset are sufficient to lengthen the day.

\section{Artificial Lights}

Various kinds of lamps may be used in the greenhouse to increase light intensity. The main types available are incandescent, fluorescent, mercury vapor, sodium and metallic halide; however, the last three are more suitable for large-scale production or in-growth chambers. These lamps differ widely in efficiency and useful life (see table 8).

TABLE 8. Characteristics of Lamps that can be used for Supplementary Lighting in the Greenhouse

$\begin{array}{lll}\text { Wattage } & \text { Per Watt } & \text { Output }\end{array}$

$\begin{array}{cccc}\text { Visible } & \begin{array}{c}\text { Non-visible } \\ \text { Radiation, }\end{array} & \\ \text { Radiation } & \begin{array}{c}\text { Convection } \\ \text { Bof }\end{array} & \begin{array}{c}\text { Hours } \\ \text { days }\end{array} & 12 \mathrm{hr} . \\ \text { Output } & \% & 100 \text { 's } & \text { Months }\end{array}$

\section{Fluorescent}

Cool White

Warm White

Gro Lux

Gro Lux-W.S.

Agro-Lite

Vita Lite

$\begin{array}{ll}40 & 70 \\ 40 & 71 \\ 40 & 20 \\ 40 & 37 \\ 40 & 41 \\ 40 & 47\end{array}$

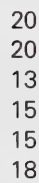

80

8-10

$12-24$

$13 \quad 87$

8-10 12-24

15

$5 \quad 85$

4-5

6-12

85

4-5

$6-12$

18

\section{Discharge}

Mercury

Metal Halide

$400 \quad 50 \quad 13$

13

$$
75
$$

20

High Pressure Sodium

400

Low Pressure Sodium

$-$

$-450$

- Cathy \& Campbell

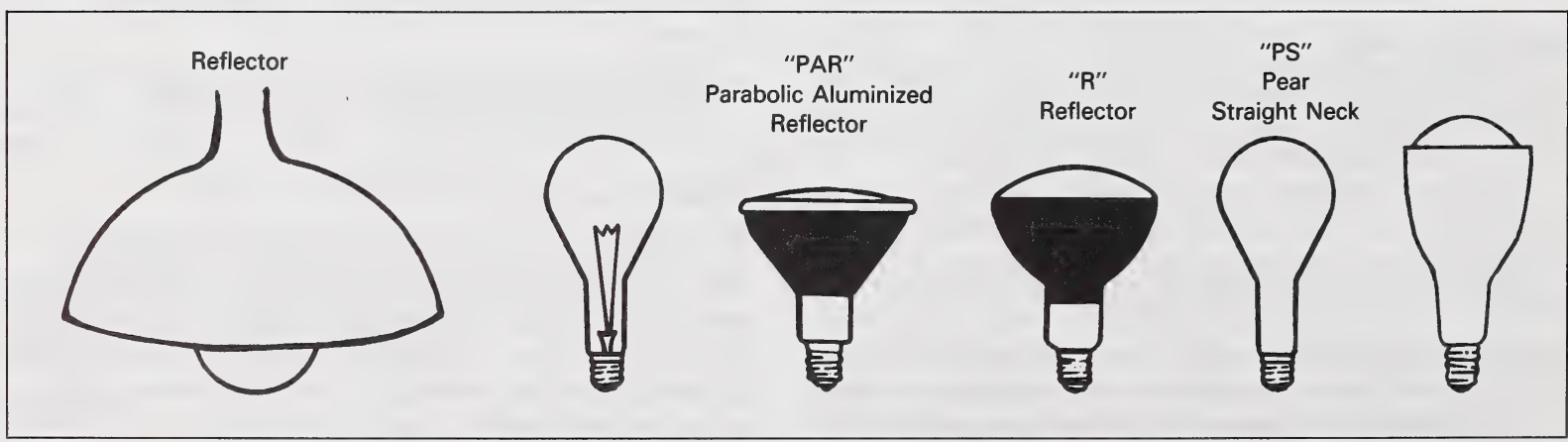

Figure 32. Incandescent lamps 
TABLE 9. Effects of Different Lights on Plants

\section{Lamp}

Fluorescent-Cool White (CW)

\section{Fluorescent Gro Lux (GL)}

Fluorescent Gro Lux WS

(GL-WS), Vita-Lite (VITA)

Agro-lite (AGRO), and Wide

Spectrum Lamps

High Intensity Discharge

Discharge Mercury ( $\mathrm{HG}$ ) or

Metal Halide $(\mathrm{MH})$

High Intensity Discharge

High Pressure Sodium (HPS)

\section{Low Pressure Sodium (LPS)}

\section{Plant Responses}

- Green foliage grows parallel to the surface of the lamp

- Stems elongate slowly

- Multiple side shoots develop

- Flowering occurs over a long period of time

Seed Germination: - Prompt uniform response

Growth: - Deep green foliage which often grows larger than plants grown under CW (cool white) or WW (warm white)

- Stems elongate slowly, extra stems develop

- Multiple side shoots develop

- Flowering occurs late, flower stalks do not enlongate

Seed Germination: - Prompt, seedlings shorter than those grown under CW or WW

Growth: - Light green foliage which tends to grow towards the lamp

- Stems elongate rapidly, long internodes

- Suppresses development of multiple side shoots

- Flowering occurs soon, flower stalks enlongate

- plants mature and age rapidly

Seed Germination: - Prompt, seedlings taller than those grown under CW of WW

Growth: - Similar to CW and WW fluoresent lamps compared on equal energy

- Stems elongate slowly

- Multiple side shoots develop

- Flowering occurs over a long period of time

Seed Germination: $\quad$ - Prompt, seedlings similar to ones germinated under CW and WW

Growth: - Similar to Gro-Lux and other color improved fluorescent lamps compared on equal energy

- Deep green foliage which often grows larger than on plants grown under $\mathrm{HG}$ and $\mathrm{MH}$

- Stems elogate very slowly, extra thick stems develop

Multiple side shoots develop

- Flowering occurs late, flower stalks do not elongate

Seed Germination: - Prompt, seedlings shorter than those grown under HG and MH

Growth: - Deeper green foliage than on plants grown under other light sources

- Stem elongation is slowed, very thick stems develop

- Multiple side shoots develop, even on secondary shoots

- Flowering occurs, flower stalks do not elongate

Exceptions: Saintpaulias, lettuce and Impatiens must have supplemental sunlight or incandescent to insure development of chlorophyll and reduce stem elongation

Seed Germination: - Prompt, extremely compact seedlings

Growth: - Paling of foliage, thinner and longer than on plants grown under other light sources

- Stem elongation is excessive, eventually becomes spindly and easily breaks

- Side shoot development is suppressed, plants expand only in height

- Flowering occurs rapidly, the plants mature and age rapidly

Exceptions: Rosette and thick-leaved plants such as Sanseveria may maintain themselves for many months. The new leaves that eventually develop will elongate and will not have the typical characteristics of the species.

Seed Germination:

- Inhibits germination of some species

Mention of a trade mark name or a proprietary product does not constitute a guarantee or warranty of the product and does not imply approval of it to the exclusion of other products that also may be suitable. 
Incandescent Lamps - The round bulbs normally used in the home can supplement natural daylight for foliage plants with low light requirements, but they do not provide enough light to meet the needs of flowering plants. They give off a large amount of red light and infrared radiation, most of which becomes heat. This causes cooling problems and burning of leaves. Because the light source is concentrated in a small area, light distribution is also restricted to a small area (see figure 32).

Fluorescent Lamps - Fluorescent tubes have a higher light efficiency and a more uniform light distribution, and they produce less heat than incandescent bulbs. There are several different types of fluorescent lamps: white fluorescent tubes, e.g., cool-white, warmwhite, day-light, etc.; and the special fluorescent tubes designed for plant growth, e.g., Grow-lux, Via-lite, Agrolite, etc. The lamps vary in their output of light in the redblue areas. The standard recommendation for gardening under artificial lights is use one cool-white and one warmwhite tube. However, many growers have had satisfactory results with other combinations. Table 9 describes what the different types of lamps do to plants, based on research results.

Supplementing the daylight in a greenhouse should only be considered during the darker seasons when the plants respond to increasing light intensities. The intensity and duration of light periods should be based on the individual requirements of the plants. As a rough guide, the lights should be arranged to provide about 170 to 220 watts of light per square metre of growing space. Lights are usually placed $30-45 \mathrm{~cm}$ above the tops of the plants; however, since distance from a light source directly affects light intensity, this will vary according to a plant's individual requirements.

The only other piece of equipment that should be considered is a timer. A timer is a special electric clock into which the light fixture is plugged. It is then plugged into an electrical outlet so that it can turn the current off and on as directed. Make certain the timer can handle a wattage of about 10 to 20 per cent more than the total wattage of the light fixtures to which it is attached.

\section{Water Systems}

In a small greenhouse, the traditional method of watering has been the watering can and garden hose. Unless you have a large number of plants, this is probably the best method. Make sure a water breaker is used to soften the force of the water.

If you have many plants or take frequent vacations, you should consider installing an automatic watering system, such as mist nozzles, spaghetti tubes or a capillary mat. A time switch wired to a solenoid valve automates all these systems.

A line strainer to filter out sand and dirt should be used with any watering system. Irrigation nozzles may also become plugged when using hard water or water with high levels of carbonates or bicarbonates. Acidification of the water with phosphoric or sulphuric acid is a means of overcoming this problem.

To warm the water before use, store it at room temperature for a day or install a hot water line and mixing valve.

\section{Mist Nozzles}

With a mist nozzle system, a polyethylene or PVC pipe is clamped on both sides of the bench. Nozzles that spray in a half circle $\left(180^{\circ}\right)$ are inserted every $75 \mathrm{~cm}$ along the pipe. Benches wider than $75 \mathrm{~cm}$ may need to alternate $180^{\circ}$ nozzles and $45^{\circ}$ nozzles, spaced $50 \mathrm{~cm}$ apart to cover the bench area (see figure 33 ).

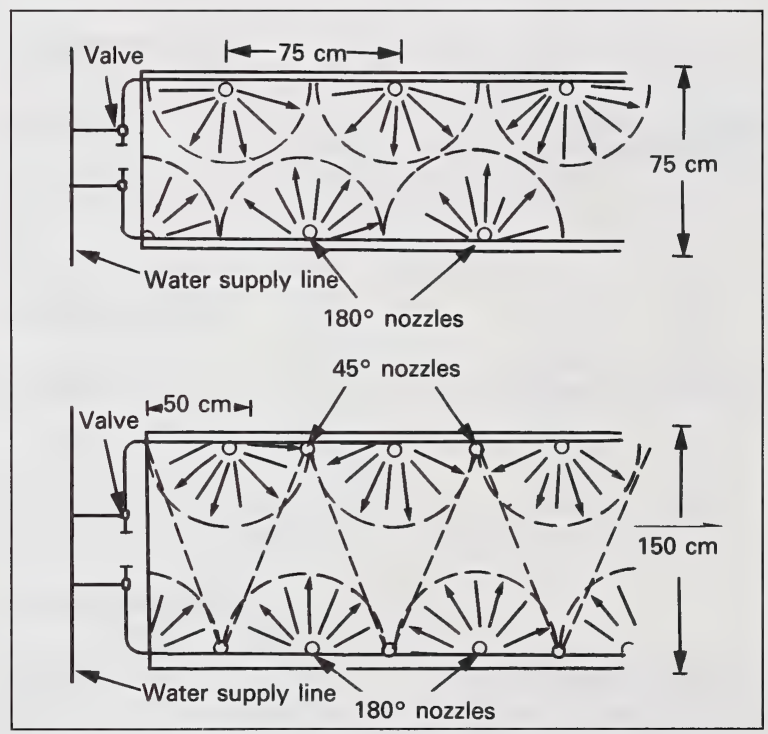

Figure 33. Mist nozzle watering system

\section{Spaghetti Tubes}

The spaghetti tube system conveniently waters potted plants. Small plastic tubes with weights on the end are inserted into the main polyethylene tube $(19 \mathrm{~mm}$ diameter) that runs down the centre of the bench. Each weight holds a tube in a pot and helps spread water evenly (see figure 34). Up to 400 pots can be watered from a $19 \mathrm{~mm}$ supply line. 


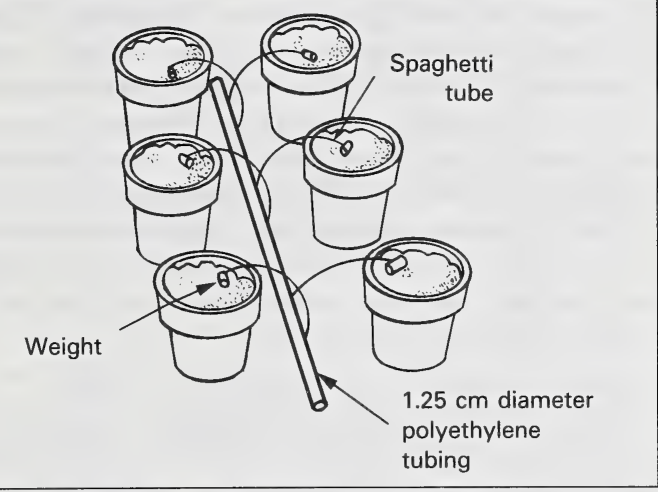

Figure 34. Spaghetti tube watering system

\section{Capillary Mat}

Installing a capillary watering system involves the laying of a fibreglass or matted-fibre mat that permits the movement of water from the mat to the plant through holes in the bottom of the pot. Spaghetti tubes are laid on the mat and the water is turned on long enough to keep the mat moist but not dripping wet. Careful attention must be paid to the growth medium when using capillary matting. A mix of 50 per cent peat and 50 per cent perlite or vermiculite is good. Algae and disease organisms may build up on the mats. Disinfectants, such as bleaches, may be used but should be hosed off after sitting for 5-10 minutes.

\section{PLANTS AND THEIR REQUIREMENTS}

\section{Growth Media}

Growing plants need a medium that will anchor the plant and provide support: one in which water, nutrients and oxygen can be stored and transferred, and one that permits the grower to move, handle and display the plants in a pot. A basic understanding of growth media, such as soil and soilless mixes, will assist you greatly in growing plants. Media recommendations for specific greenhouse plants will be supplied in a later section.

Soil - Soil consists of four types of material: mineral particles (very small broken pieces of rock), decayed organic matter, water and air. Variations in the proportions of these four components are responsible for important differences between soils and greatly affect their quality for gardening. Mineral particles vary in size from very fine clay particles (which are invisible to the naked eye) to coarse sand particles.

Soil texture refers to the relative percentage of sand, silt, and clay in a soil. A texture triangle illustrated the percent of sand and clay in soils of various textures (figure 35).

Silt loams, loams and sandy loams are usually the most suitable for gardening purposes. Soils of these textures drain well and allow sufficient air to enter so that the soil doesn't become waterlogged.

Physical characteristics of soils that are too "heavy" (too much clay) or too "light" (too much sand) can be improved by the addition of organic matter, such as peat moss. If sufficient organic matter is added, "heavy" soils can develop a desirable crumb-like structure which makes them easier to work and "light" soils can develop an increased capacity to hold water.
Most soils found in Alberta are not the best medium for growing plants indoors because they often contain too much clay. A general purpose soil mix should consist of $1 / 3$ soil, $1 / 3$ peat moss and $1 / 3$ perlite or sand. The perlite or sand will further help break up a "heavy" soil and will increase drainage.

As you increase your knowledge of individual plant requirements, the amounts of peat, sand and perlite added should be varied for each plant grown. Formulas for several soil mixes are listed in Appendix 5.

It is a good idea to get your soil tested before making up a soil mix so that you know how much fertilizer or physical amendments to add and whether the $\mathrm{pH}$ is optimal. Soil sampling can be arranged through your district agriculturist for a fee of $\$ 20$.

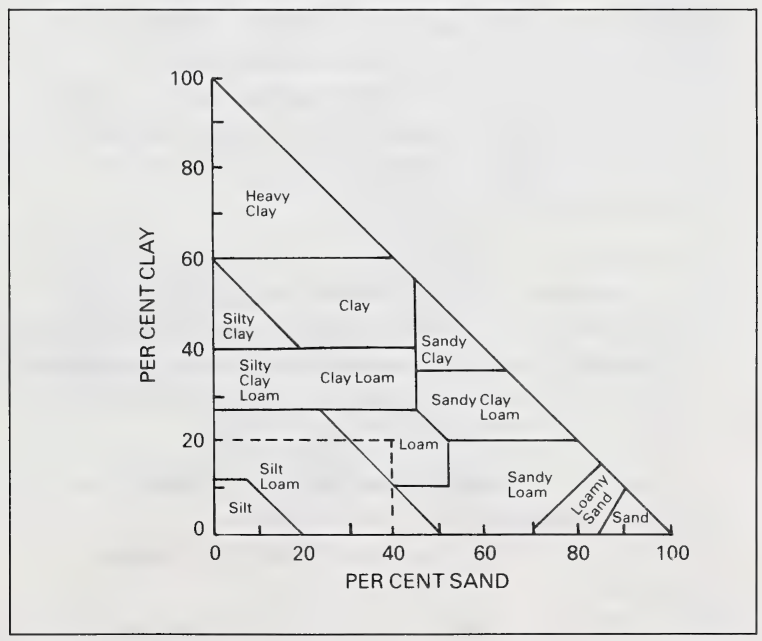

Figure 35. Soil texture triangle 
Soil Pasteurization - Soil may contain a variety of weed seeds, diseases and insects that can harm your plants. It is very important, therefore, that you treat your soil with either heat or a chemical to kill these organisms. After treating soil, make sure that you store it in a sterilized container so pests and pathogens are not reintroduced.

Temperatures up to $82^{\circ} \mathrm{C}$ will kill pathogenic organisms but will not harm the useful bacteria. Small batches of soil can be baked in the oven:

- Place 7-10 cm of soil in a cake pan and moisten thoroughly (don't soak).

- Cover with aluminum foil, insert a meat thermometer into the centre of the soil and place in the oven.

- Set the oven at $93^{\circ} \mathrm{C}$ for one-half hour. Make sure the temperature in the soil mix does not go higher than $82^{\circ} \mathrm{C}$ or beneficial bacteria will be killed.

- Remove from oven and allow to cool. The odors may be objectionable but are not harmful.

For larger batches, there are small electric soil pasteurizers that heat 0.1 cubic metre at once. Operating cost is comparable to that of a home cloths dryer.

Soilless Mixes - Soilless mixes, which do not contain soil but consist of inert mineral and organic particles and fertilizers, are an alternative to soil. Soilless mixes are especially useful where significant deterrents to good production occur, such as inadequate drainage,

unavailability of good soil or soil disease build-up. Soilless mixes are pest-free (eliminating the need for pasteurization), lightweight, easy to handle and can be excellent for plant growth. However, since soilless mixes are inert, contain very little fertilizer and do not have the buffering capacity of soil, more attention must be given to the nutritional requirements of plants growing in a soilless mix.

The following materials are often used in soilless mixes: calcined clay, sand, perlite, vermiculite, peat moss, sawdust, bark, compost, viterra, charcoal and osmunda fibre. Fertilizer is either mixed in with these materials or added at watering time. Several formulas for soilless mixes are given in Appendix 5.

Hydroponics - Hydroponics is the growing of plants in water or an inert soilless medium and supplying the needed nutrients in solution. It can be used for the same reasons as other soilless mixes or by those who wish to experiment. A few points regarding hydroponics should be noted:

- Hydroponics is not new; methods were established well over a century ago.

- Plant growth and yield are similar to those plants grown in soil.

- The nutritional value of crops grown hydroponically is not greater than that of plants grown in soil.
Hydroponics can be classified as liquid culture or aggregate culture. In liquid culture systems, plant roots are suspended in a nutrient solution by an aerial support system with nutrient solution constantly circulating about the roots. The liquid culture method is generally too expensive for the home hobbyist because of the cost of the support system and the need for aerating the solution. Aggregate systems are often less expensive and easier to construct than liquid systems since an aggregate, such as sand, gravel or sawdust, often provides sufficient support and anchorage for plant roots.

Aggregate System - The basics of an aggregate hydroponic system include a watertight container for growing plants, an aggregate, backuts to hold the nutrient solution and lengths of rubber hoses. Plants are grown in the aggregate and a nutrient solution is allowed to drain through this system often enough to meet the plant's requiements for water minerals. A manually operated and an automatically operated hydroponic garden are shown in figures 36 and 37, respectively. Variations on these hydroponic systems can be built at home or they can be purchased from commercial outlets (see Appendix 3 ).

Adding Nutrient Solutions - Different methods can be used to add nutrient solutions to plants that are grown in an aggregate, but subirrigation techniques are most often used. With subirrigation the solution is allowed to flow into the growing container at least 3-4 times daily, either by gravity or by pumping from a tank that is below the container. The container should be filled to slightly above the level of the aggregate and allowed to drain immediately. Nutrients can also be applied by surface irrigation, such as by allowing the solution to drip very slowly and continuously onto the surface of the aggregate from an elevated tank. This method is more successful with fine sand than with coarser aggregates. Regardless of the system used, the container must be well drained so that the roots have sufficient aeration.

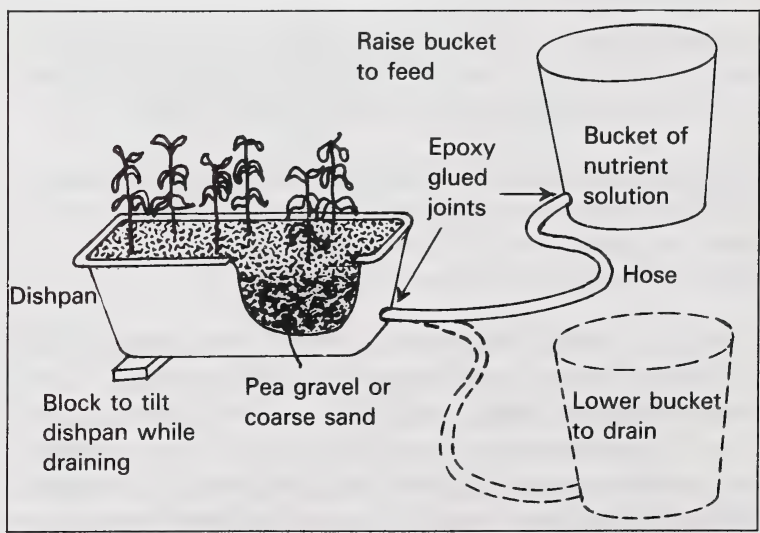

Figure 36. A simple manual hydroponic garden 
Containers - Any container that is used should either be made of or coated with nontoxic material. The size of container depends mainly on the kind of plant to be grown and the duration of the growing period. Glass, plastic or earthenware jars ranging in size from 1 up to $10 \mathrm{~L}$ are suitable for small scale operations. A $5 \mathrm{~L}$ plastic pail is inexpensive, nontoxic and is sufficient for a single, large tomato plant or many (24) small plants until they are 4-5 weeks old. It is possible to build long, narrow, shallow troughs of wood, sheet metal (which nutrient salts must not be able to corrode) or cement for larger scale operations. If troughs are used, they must be angled at a slope of 1:100 or greater to keep the nutrients flowing through the growing medium. If the container used is not opaque, it must be painted on the outside or covered to prevent algal growth, which is encouraged by light.

Nutrient Solutions - A critical factor in determining the success of hydroponics is the nutrient solution used.

There are 16 elements generally considered to be essential for growth of higher plants: hydrogen, carbon, oxygen, nitrogen, potassium, phosphorus, sulphur, magnesium, calcium, iron, copper, zinc, manganese, boron, molybdenum and chlorine. Except for carbon, these elements must all be provided as various salts and compounds in a nutrient solution in the right amounts and in the proper balance. The inert material in the bed retains nutrients for only a short time, and unlike soil, it will not buffer a solution that contains too much fertilizer.

Many different nutrient solutions have been found to be satisfactory with various plant species. It is difficult to derive an ideal formulation for a crop since this depends on many variables which cannot be controlled: kind of plant, stage of plant growth, part of plant being harvested, the season and the weather.

Nutrient solutions can be prepared by measuring, dissolving and mixing salt forms of the required elements according to a formula or by using a commercial premixed, water-soluble fertilizer. For a beginning amateur grower it is much simpler to purchase premixed fertilizer. Table 10 presents a list of some of these water-soluble preparations and indicates the approximate amount of fertilizer required to prepare 10 litres of nutrient solution. See Appendix 6 for instructions on preparing a nutrient solution from scratch.

Water is removed from the solution through absorption by the plants or by evaporation from the surface of the solution. For these reasons, daily additions of water may be necessary to bring the solution to its original volume. Excessive removal of water should be avoided to prevent the salt concentration from becoming high enough to adversely affect the plant. Since fertilizer salts are also removed from the solution, it is important to replace the solution once a month when the plants are small and once a week when they are larger.

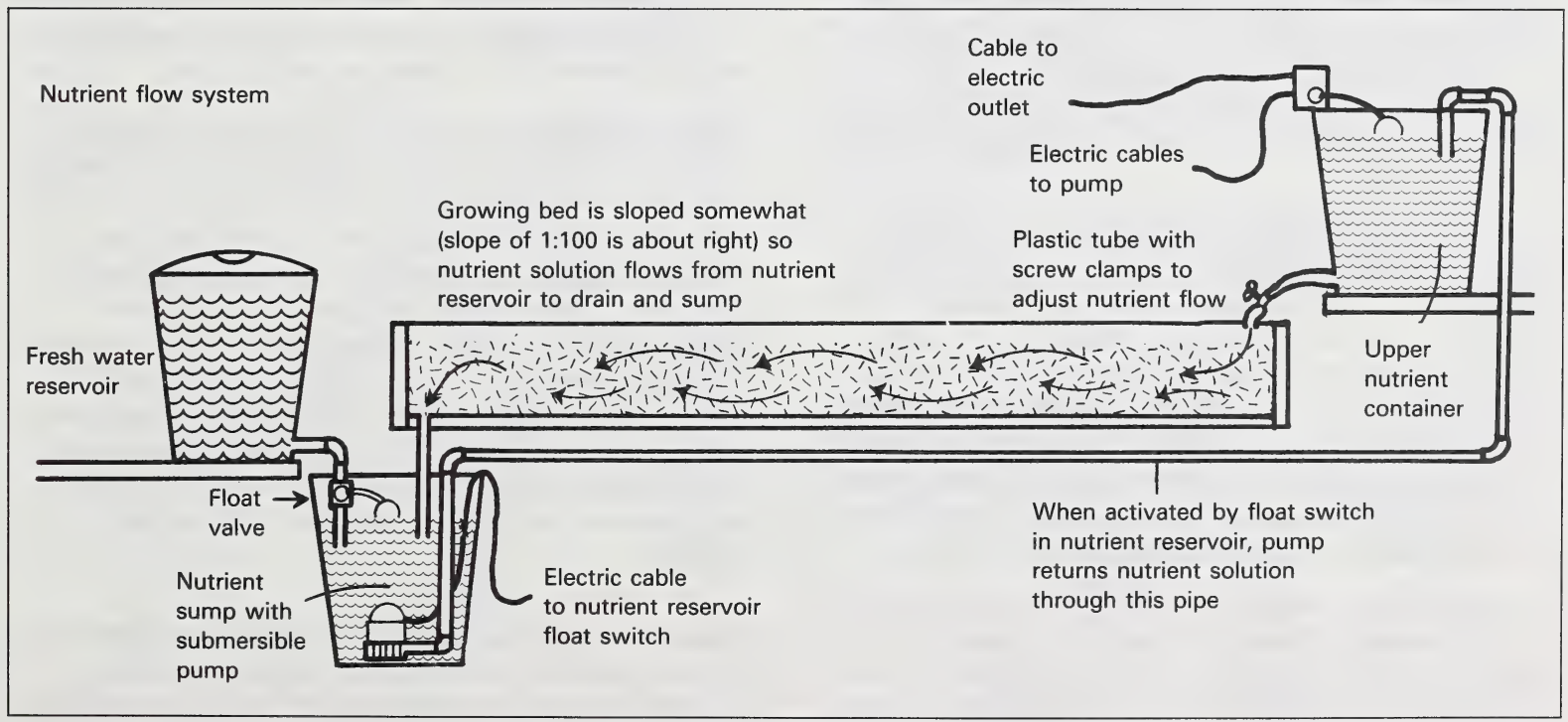

Figure 37. An automatic hydroponic garden 


\section{Fertilizing}

As discussed in the section on hydroponics, plants have specific requirements for minerals that must be provided by the growth medium. The minerals combine and react under the stimulus of light, heat and water to trigger the various growth activities within a plant. Fertilizers that contain essential minerals need to be added to the growth medium over time to replace the nutrients taken up by the plants.

Types of Fertilizer - Fertilizers come in a variety of concentrations and formulations. They can contain only one nutrient or many; they may release nutrients slowly or quickly; and they can be either organic or inorganic.

TABLE 10. Some Commercial Preparations of Water-Soluble Fertilizers

\begin{tabular}{|c|c|c|c|}
\hline $\begin{array}{c}\text { Grade or } \\
\text { Analysis }\end{array}$ & $\begin{array}{c}\text { Amount for } \mathbf{1 0} \text { litres } \\
\text { of nutrient solutions } \\
\text { (g) }\end{array}$ & $\begin{array}{c}\text { Grade or } \\
\text { Analysis }\end{array}$ & $\begin{array}{c}\text { Amount for 10 litres } \\
\text { of nutrient solutions } \\
\text { (g) }\end{array}$ \\
\hline $9-45-15$ & 10 & $16-4-12$ & $17-3-38$ \\
$10-45-15$ & 10 & $17-17-7$ & 6 \\
$10-30-10$ & 10 & $20-5-30$ & 6 \\
$10-30-20$ & 10 & $20-20-20$ & 6 \\
$10-33-27$ & 10 & $21-7-7$ & 6 \\
$10-50-10$ & 10 & $24-12-18$ & 5 \\
$10-52-10$ & 10 & $25-5-20$ & \\
$12-52-17$ & 10 & $25-10-10$ & 5 \\
$15-10-30$ & 10 & $28-14-14$ & 5 \\
$15-15-15$ & 8 & $20-10-10$ & 5 \\
$15-15-30$ & 8 & & 5 \\
\end{tabular}

Courtesy of the Ontario Ministry of Agriculture and Food

Every fertilizer is described in terms of three numbers, for example, 10-52-10. These numbers represent, in order, the percentage of nitrogen (expressed as total $\mathrm{N}$ ), phosphorus (expressed as $\mathrm{P}_{2} \mathrm{O}_{5}$, phosphorus pentoxide) and potassium (expressed as $\mathrm{K}_{2} \mathrm{O}$, potassium oxide), the three nutrients used in largest quantities by plants.

Products that contain at least these three nutrients are called complete fertilizers and are generally recommended for plant growth.

Fertilizer can be applied as dry granules, as diluted liquids, as dissolved crystals or as slow-release pellets. Dry granules do not provide nutrients immediately because they must first become dissolved in the water around soil particles before they are available to the plant. Liquid feeding, such as by diluting a fertilizer concentrate or by dissolving crystals, allows for more frequent feeding than dry granules and thus better control of plant growth. These types of fertilizer are also immediately available to the plant because they are already dissolved in water.

Another means of keeping nutrients constantly available for plant growth is through the use of controlled or slow release fertilizers. This type of fertilizer is especially useful with soilless mixes because fertilizer is released gradually over a period of time.
Organic versus Inorganic - Fertilizers can be classified as organic or inorganic. Organic nutrients are made up of natural plant and animal materials, such as manure, bones, ground fish, dried blood, etc. Inorganic fertilizers are chemical compounds, some of which are naturally mined materials while others are manufactured.

Organic fertilizers are much less concentrated and must be broken down by soil micro-organisms into a chemical form usable by plants. These two qualities make it difficult to overfertilize plants with organic fertilizers. Inorganic fertilizers are usable by plants, so are much faster acting than organic fertilizers. Although some organic gardeners make a distinction between organic and inorganic nutrients, the plant is able to take up each nutrient in one chemical form only; therefore, the source is irrelevent to the plant. The fruit of plants grown with organic fertilizers will not necessarily be of better quality or nutritional value than those grown with inorganic fertilizers.

\section{Quantity and Timing of Fertilizer Applications}

- Each fertilizer product comes with directions for application. Follow the directions for dilution and attempt to apply fertilizer when it is needed by the plant. You 
learn by experience that when the plant is in an active stage of growth it needs more food, and when it is becoming dormant it needs less. For example, during the dark days of winter, plants use little fertilizer.

Regular application of fertilizer will prevent nutrient deficiencies, but it commonly results in sufficient build-up of fertilizer salt in the medium to cause plant damage (especially in beds and containers without free drainage). The first symptom of excessive salt build-up may be slow growth, yellowing of the leaves, or wilting. As the salt concentration increases, symptoms can also include leaf scorch, leaf shed and plant collapse. Salts from your water supply can compound the problem. Excess salts can be removed by leaching the growth medium. Flush out pots three times using about $1 \mathrm{~L}$ of water each time for $15 \mathrm{~cm}$ pot. Wait one hour between each flushing. It may be necessary to fertilize lightly after leaching.

Fertilizer recommendations for individual plants are given in subsequent sections.

\section{Water}

\section{Water Quality}

Large quantities of water are used in a greenhouse for irrigation and fertilization. Have your water analyzed through your nearest district extension office. Request an analysis for irrigation purposes, along with an additional analysis for boron. Send a copy of the analysis to the greenhouse specialists at the Alberta Special Crops and Horticultural Research Center, Bag Service 200, Brooks, Alberta, TOJ 0J0 or Alberta Tree Nursery and Horticulture Centre, R.R. 6, Edmonton, Alberta T5B 4K3, for interpretation of the results. The following broad guidelines can be used in the interpretation of water quality.

Electrical Conductivity (EC) of the water: For waters having a Sodium Absorption Ratio (SAR) of less than 6.0 .

Water with an EC of $0.8 \mathrm{mmhos} / \mathrm{cm}$ or less is considered suitable for irrigation of cucumber, tomatoes and lettuce, under normal use conditions.

Water with an EC between 0.81 and $2.2 \mathrm{mmhos} / \mathrm{cm}$ is considered usable for irrigation, but only when accompanied by special management practices. Water with an EC above 2.2 is not recommended as the sole source of water for irrigation. Consider collecting rain water from the roof of your greenhouse to mix with such water.

\section{Special Management Practices}

Provide adequate drainage.

Never allow the growing medium to become more than moderately dry. Maintain a higher moisture level in the rooting zone of plants than would be necessary with higher quality water. Reduce stress by designing a well drained mix.

Analyze soil samples periodically to monitor the salt level.

Leach periodically to remove excess salts from the medium. Use table 11 as a guide.

\section{Acidifying Water Supplies}

Most of the water in Alberta cities is alkaline and moderately hard-it contains moderate amounts of calcium and magnesium. However, most rural water supplies are soft in nature, containing moderate or large quantities of sodium. Soft water or chemically softened water is not suitable for growing plants.

Hard water can be used for growing plants but calcium can cause several problems, all of which can be alleviated by acidifying the water supply. Remember, water $\mathrm{pH}$ also affects the activity of chemical sprays. Many chemical sprays remain active longer in lower $\mathrm{pH}$ solutions than in high $\mathrm{pH}$ solutions.

The calcium in Alberta water supplies is largely in the form of calcium carbonate or bicarbonate, which precipitates out as the familiar white deposit or calcium

TABLE 11. Leaching Guidelines as related to Water Quality.

\begin{tabular}{|c|c|c|c|c|}
\hline $\begin{array}{l}\text { EC of Water } \\
\mathrm{mmhos} / \mathrm{cm}\end{array}$ & $\begin{array}{l}\text { Parts per Million } \\
\text { Salts (ppm) }\end{array}$ & $\begin{array}{c}\text { Leaching } \\
\text { Requirements \% }\end{array}$ & $\begin{array}{l}\text { Recommended } \\
\text { Leaching Interval }\end{array}$ & $\begin{array}{c}\text { Interpretation of } \\
\text { Water Quality }\end{array}$ \\
\hline 0.35 & 245 & 5.0 & 12 weeks & excellent \\
\hline 0.40 & 280 & 6.0 & 9 weeks & very good \\
\hline 0.60 & 420 & 7.5 & 6 weeks & good \\
\hline 1.00 & 700 & 12.5 & 4 weeks & fair \\
\hline 1.40 & 980 & 17.5 & 3 weeks & permissible \\
\hline 1.80 & 1280 & 22.5 & 2 weeks & permissible \\
\hline 2.20 & 1540 & 27.5 & 1 week & excessive - too salty \\
\hline
\end{tabular}

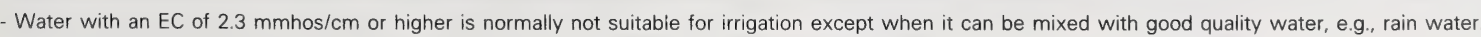


carbonate. The continued use of hard water for irrigation can lead to an accumulation of calcium in the growing media, unless it is leached out by heavy nitrogenous feeding. When hard water is used for misting purposes, it can leave white scales on leaf surfaces, which reduces photosynthesis.

Carbonates and bicarbonates interfere with the absorbption of fertilizer as the amounts of these materials in the water become greater. Generally, there are few carbonates in water until the $\mathrm{pH}$ of the untreated water is above 8.3 , but carbon dioxide in the air dissolves in water and makes bicarbonates with various minerals in solution. Acidification of the water with phosphoric, sulfuric or nitric acid is a means of overcoming the injurious effects of carbonates or bicarbonates by neutralization. Do not add acid to the fertilizer concentrate tank. Contact the greenhouse crops specialist at Brooks and at Edmonton for calculating the exact amounts of acids needed. Figure 38 is a typical graph for a water sample containing $100 \mathrm{ppm}$ of calcium. Here, $275 \mathrm{ml}$ of concentrated nitric acid are required to bring the $\mathrm{pH}$ to 5.9 .

This also provides $60 \mathrm{ppm}$ of nitrogen. The graph is only an example. Your water supply should be assessed individually.

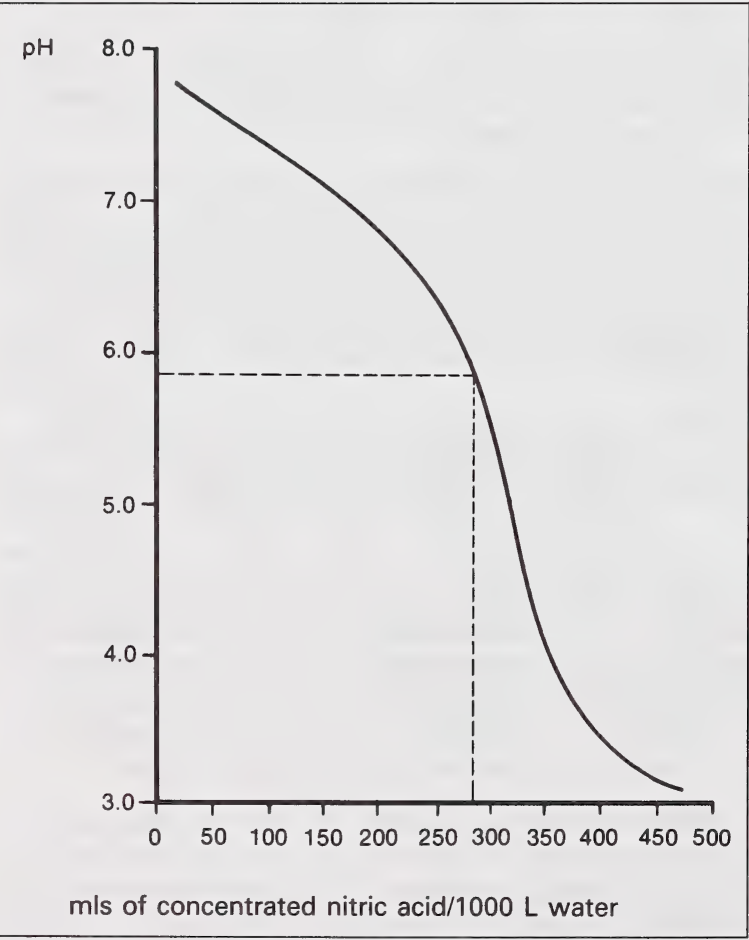

Figure 38. Effect of adding acid on $\mathrm{pH}$ of a water sample
Phosphoric Acid - Phosphoric acid can be added through a fertilizer injector. An injector with two heads is suitable. Use injector heads meant for acids. An analysis of the water in terms of carbonate hardness is needed and can be obtained by subtracting noncarbonate hardness from total hardness. Generally in Alberta, 2-6 $\mathrm{ml} / 100 \mathrm{~L}$ of 85 per cent phosphoric acid is adequate for $\mathrm{pH}$ control.

Nitric Acid - Concentrated nitric acid (70 per cent) can also be used to acidify water. It also provides some nitrogen feed, helping to offest the cost of applying the acid. For each $1000 \mathrm{ml}$ of concentrated nitric acid added to $1000 \mathrm{~L}$ of water, $220 \mathrm{ppm}$ of nitrogen is supplied.

To accurately assess the amount of nitric acid required for your particular water supply, send a water sample to the greenhouse specialist at Brooks or Edmonton. Samples can be submitted through the district agricultural offices.

Sulfuric Acid - Sulfuric Acid can be used to lower the $\mathrm{pH}$ of water. The amount has to be calculated based upon individual water quality. If sulfates are more than $100 \mathrm{ppm}$, then the use of sulfuric acid should be avoided.

Hydrochloric Acid - The use of hydrochloric acid should be avoided because of its chlorine content.

Remember, concentrated acids are dangerous chemicals and must be handled with care. Always add acid to water not water to acid. Acidified water is corrosive and may eat away your irrigation system.

\section{Chlorination}

Chlorination of city water to reduce the population of various micro-organisms is accomplished by dissolving chlorine gas (under pressure) in the water. The amount that goes into solution is relatively small, and although there may be a decided chlorine taste or smell, the water is safe for plants.

\section{Fluoridation}

Fluoridation of water is common in many city water supplies and is included to minimize tooth decay in children. When water is fluoridated, sodium fluoride is added to provide about $3 \mathrm{ppm}$ of fluoride in the water. The fluoride content is not harmful to cucumber plants.

\section{Boron}

Boron is a fertilizer element that occasionally occurs in such quantities in Alberta water supplies as to be phytotoxic. When the level of boron is one or more ppm, the water is considered unsatisfactory for use. There is no 
inexpensive method for removing boron and an alternative source of water must be considered.

\section{Sodium}

Sodium is another element that is usually present in well water throughout much of Alberta. It is not required for plant growth and can reach levels that are toxic to plants. If sodium is above $100 \mathrm{ppm}$, either reverse osmosis should be considered to remove it or an alternate source of water should be found. Water with up to $100 \mathrm{ppm}$ can be used if the potassium level is maintained above 100 ppm and special management practices are followed (eg., regular leaching, good drainage, etc.).

\section{Pollutants}

Pollutants of various kinds, some of which are toxic to plants, may be found in certain water supplies. These materials may have been either discharged inadvertently into a stream or buried and then later infiltrated into the ground water. Long lasting herbicides, like Picloram (Tordon), can pollute water supplies and cause serious damage to crops. The best means of detection is to conduct a biological test with water intended for irrigation. Grow seeds of tomato and fababeans. Watch for an abnormal growth symptoms such as crinkling of new leaves or abnormal spindly stems. This can serve as a test of the suitability of your growth medium as well.

\section{Water Quantity}

Water is taken into plants through the roots and is eventually lost (transpired) into the air through the leaves in the form of water vapor. Physiologically, there should be a balance between the amount of water available in the soil and the amount transpired. If there is too much water, the roots cannot get oxygen and the plant drowns If there is too little water, the plant wilts.

The amount of water a plant needs depends upon the stage and rate of growth, the container used, environmental conditions and the plant growth medium. For example, germinating seeds and rapidly growing plants require a lot of water. Bright light and high temperatures increase transpiration and thus the need for water. A plant growing in very porous mix will need more water than a plant growing in a less porous one.

It is easy to tell when a plant is receiving too little water; however, it is difficult to tell when a plant is receiving too much. The simultaneous presence of the following symptoms indicates overwatering: yellowing of leaves, leaf drop, sparse and weak root system, and soft or rotten large roots. Another sign of overwatering is edema.

Edema occurs when the plant takes up more water than it can transpire, causing water to accumulate in leaf cells until they burst. A brown corky-like growth often forms over the damaged cells. Edema is more prevalent when the soil temperatures are warmer than the surrounding air temperatures.

To reduce the possibility of overwatering, use only pots with drainage holes. Water thoroughly until water drains from the pot and water again only when the top $2.5 \mathrm{~cm}$ of soil becomes dry. For most plants, infrequent thorough waterings are much better than frequent light waterings.

\section{PEST MANAGEMENT}

Any organism that curtails normal plant development can be considered a pest. Pests, therefore, include insects, fungi, bacteria and viruses. A greenhouse provides an ideal environment for the growth of many of these organisms.

Many plant problems are not due to disease or insect pests but result from poor cultural practices, such as allowing salt build-up, overwatering, using contaminated soil, etc. Before suspecting a parasitic disease or an insect problem, be sure that you have ruled out these other possibilities.

If using pesticides, remember that they are not dangerous if used carefully, but they are poisonous and should be treated as such. Applying chemicals in a greenhouse is more dangerous than doing so outdoors because of limited ventilation.

\section{Pesticide Usage}

- Read the label - read the fine print.

- Store all pesticides in a locked area, away from food or feed.

- Store volatile herbicides in a separate locked area.

- Observe the waiting period on the pesticide label before harvest.

- Always store pesticides in the original container.

- Use only on recommended crops at the rate indicated on the label.

- Wear protective clothing, such as long sleeves, a repellant coat, rubber gloves and a mask.

For more information on pesticides and their use, see the publications list in Appendix 1. 
TABLE 12. Pest Control Recommendations

\begin{tabular}{|c|c|}
\hline PEST & CONTROL \\
\hline Ants & $\begin{array}{l}\text { Cultural - remove and destroy nests. } \\
\text { Pesticide - chlorpyrifos*** diazinon**, } \\
\text { pyrethrins, propour. }\end{array}$ \\
\hline Aphids & $\begin{array}{l}\text { Cultural - insecticidal soap, diatomeceous } \\
\text { earth, predators such as ladybird beetles and } \\
\text { parasitic wasps, removal of heavily infested } \\
\text { plants. } \\
\text { Pesticide - chlorpyrifos**, diazinon**, } \\
\text { malathion pyrethrin or other pyrethroids (eg., } \\
\text { tetramethrin, resmethrin and allethrin), } \\
\text { rotenone, propofur. }\end{array}$ \\
\hline $\begin{array}{l}\text { Cyclamen } \\
\text { mites }\end{array}$ & $\begin{array}{l}\text { Cultural - insecticidal soaps, predator mites, } \\
\text { destroy heavily infested plants. } \\
\text { Pesticide - dicofol, tetramethrin }\end{array}$ \\
\hline Fungus gnats & $\begin{array}{l}\text { Cultural - let soil surface dry out } 3 \text { to } 5 \mathrm{~cm} \\
\text { deep. } \\
\text { Pesticide - Chlorpyrifos** }{ }^{*} \text { diazinon** or } \\
\text { malathion as soil drench; malathion or } \\
\text { pyrethrins as spray. }\end{array}$ \\
\hline Leaf miners & $\begin{array}{l}\text { Cultural - hand pick infested leaves, sticky } \\
\text { yellow traps. } \\
\text { Pesticide - none registered for use indoors. }\end{array}$ \\
\hline Mealy bugs & $\begin{array}{l}\text { Cultural - pick bugs off with a toothpick or } \\
\text { wipe off with soft, damp cloth; insecticidal } \\
\text { soap; touch bugs with Q-tips or paint brush } \\
\text { dipped in denatured alcohol; diatomaceous } \\
\text { earth. } \\
\text { Pesticide - chlorpyrifos**, diazinon**, } \\
\text { malathion. }\end{array}$ \\
\hline Nematodes & $\begin{array}{l}\text { Cultural - use sterilized potting soil only. } \\
\text { Grow nematode resistant cultivars. } \\
\text { Pesticide - none }\end{array}$ \\
\hline Scale insects & $\begin{array}{l}\text { Cultural - wipe or pick off scales, } \\
\text { insecticidal soaps. } \\
\text { Pesticide - chloryprifos**, diazinon**, } \\
\text { malathion, methoxychlor. }\end{array}$ \\
\hline Slugs & $\begin{array}{l}\text { Cultural - greenhouse sanitation, dishes of } \\
\text { beer. } \\
\text { Pesticide - metaldehyde, methiocarb (bait, } \\
\text { dust or spray) }\end{array}$ \\
\hline Spider mites & $\begin{array}{l}\text { Cultural - insecticidal soap, predator mites, } \\
\text { maintain high humidity. } \\
\text { Pesticide - dicofol, malathion, propofur, } \\
\text { tetramethrin. }\end{array}$ \\
\hline Thrips & $\begin{array}{l}\text { Cultural - remove spoiled flowers and badly } \\
\text { damaged leaves. } \\
\text { Pesticide }- \text { chlorpyrifos**, diazinon**, } \\
\text { malathion, resmethrin, tetramethrin, propofur. }\end{array}$ \\
\hline Whitefly & $\begin{array}{l}\text { Cultural - insecticidal soaps, parasitic wasps } \\
\text { (Encarsia formosa). } \\
\text { Pesticide - chlorpyrifos**, diazinon }{ }^{* *} \text {, } \\
\text { malathion, resmethrin, tetramethrin, } \\
\text { rotenone. }\end{array}$ \\
\hline
\end{tabular}

* Ensure that the plant is not sensitive to the chemical chosen. Where applicable, some common trade names have been included in brackets.

** Registered for use indoors on noncommercial houseplants in the dust form only.

\section{Diseases}

The number of diseases that can attack greenhouse plants is large and their identification is often difficult for the amateur diagnostician. A number of the common, easily identified diseases will be discussed here.

Sanitation is a basic step in control of greenhouse plant diseases. Prevention of disease is much less costly than attempts to control established disease problems.

- Keep walkways and surface of beds free of plant debris.

- Control weeds in and around the greenhouse.

- Remove dead or dying plants and plant parts immediately.

- When bringing new stock to the greenhouse, carefully screen it for infections - keep it well separated from existing stock.

- Pasteurize soil (see page) and sterilize benches and equipment (use a 10 per cent solution of bleach) and check new batches of soil, even if pasteurized, for the possibility of high soil salts or persistent herbicides. Grow test seedlings in the new potting mix, e.g., tomato seedlings to test for high salts, and oats and sunflowers for herbicides.

- Keep hose nozzles off the ground.

\section{Fungal Disease}

Fungi are the cause of most greenhouse disease. Unlike other disease organisms, fungi can be readily controlled with chemicals.

Damping off - Damping off is a soil-borne disease that attacks seedlings shortly after germination or cuttings in the process of rooting. The stems rot at soil level, causing the young plants to topple over. Plant seed or cuttings in a clean, well-prepared rooting medium in a sanitized area of the greenhouse. Avoid overwatering, overcrowding and overfertilizing. Provide good ventilation and water only in the morning. Fungicides such as benomyl, captan and ethazol may also be used.

Botrytis (Gray mold) - Gray spore masses may cover leaves, stems and flowers causing them to become soft and rotten. High humidity, crowding of plants, and allowing dead flowers and leaves to remain on the plant can lead to an outbreak of this disease. To control Botrytis, avoid these conditions and increase air circulation. Benomyl or captan may be applied as control measures.

Powdery Mildew - This white powdery growth of fungus may be found on leaves of many plants, particularly African violets, begonias and cucumbers. Avoid damp, shady locations. Water only in the morning and increase air circulation. Benomyl or sulphur dust are recommended controls. 


\section{Viral Disease}

The symptoms of viral disease include leaf disfiguration, such as mottling, stripping, and crinkling (similar to damage caused by some insects). As a rule, viruses can survive only inside living plants or plant parts and are generally highly specific to the plant species they infect. Tobacco mosaic virus, which can infect tomatoes and orchids, is an exception in that the virus can survive on contaminated surfaces and in the dried plant material.

Cultural control must be undertaken because as there is no chemical control. Viral diseases are spread by cutting tools, insects, propagation of virus-infected plants and by contaminated hands. If you suspect a viral disease, remove and destroy infected plants and disinfect tools regularly by immersing them in boiling water or 10 per cent bleach solution.

\section{Bacterial Disease}

Control of bacterial disease is very difficult. Luckily, there are only a few bacteria cause problems in a greenhouse. Symptoms of bacterial disease include leaf spot, wilt and root rot. Good sanitation practices will reduce the chance of bacterial infection.

\section{Insects}

\section{Identification}

Before an insect can be controlled, it must be identified. Common insect pests found in the greenhouse are outlined in Table 13.

\section{Control}

Many greenhouse growers are turning to integrated pest management rather than relying totally on use of chemicals. Integrated pest management combines' cultural, biological and mechanical control methods with chemical control to lessen the problems associated with chemical use. This is an effective but complex control practice. For further information, contact the greenhouse specialist at the Alberta Special Crops and Horticultural Research Center, Brooks.

Biological Control - Biological control involves controlling insects with other organisms (predators or parasites) or with natural compounds. Natural compounds commonly used include organic plant extracts, such as nicotine, pyrethrum, and rotenone (derris dust). Predators currently available for use at home include lacewings, praying mantis, ladybugs and several species of wasps (see Appendix 3 for sources of supply). Only one parasite, Bacillus thuringensis, is currently available for home use. This organism is a bacterium and is useful in controlling caterpillars (trade names - Dipel, Thuricide).

Effective use of predators and parasites in an integrated pest management control program is complex.

Mechanical Control - Mechanical control refers to the use of baits and traps. Baits formulated with metaldehyde are commonly used to control slugs. Traps using sticky substances to attract and hold insects are effective, especially if painted yellow. There are also light traps available that control insects by electrocution or by drowning them in soapy water.

Chemical Control - In situations where an insect problem gets out of hand, biological and mechanical controls are not rapid enough, and chemicals must be used. Chemicals can be applied as fumigants, dusts, sprays or as granules applied to the soil. Each formulation has advantages and disadvantages. Fumigants are very poisonous and consequently are not registered for domestic use. Dusts are easy to apply and often contain a fungicide for added protection. They do, however, leave unsightly residues. Sprays provide very thorough coverage and thus control; however, a sprayer is required. Sprays are either contact or systemic. To be effective, contact sprays must hit the insect to be controlled. Systemics are taken up by the plant and transmitted internally, killing insects feeding on any part of the plant. The granular formations of insecticide applied to the soil are also systemic. In this case, however, the insecticide is taken up by the roots, not the leaves. Granular insecticides are easy to apply and provide longer term control than many sprays.

Since plants are sensitive to some chemicals, read insecticide labels for phytotoxicity information. If you are in doubt, treat one leaf before treating the entire plant.

Plants in the greenhouse are more susceptible to injury from insecticides than are plants in the open, and sprays should usually be used at two-thirds or one-half the rate recommended for garden plants.

See table 12 for chemical and other control recommendations for common greenhouse pests. 
TABLE 13. Common Greenhouse Pests

\begin{tabular}{|c|c|c|c|}
\hline PEST & IDENTIFYING FACTORS & DAMAGE & COMMENTS \\
\hline Aphids & $\begin{array}{l}\text { Soft bodied insect; green, yellow, pink } \\
\text { or brown; up to } 0.5 \mathrm{~cm} \text { long; with or } \\
\text { without wings; feeds by sucking; easily } \\
\text { observable. }\end{array}$ & $\begin{array}{l}\text { Feeds on stem tips and buds causing } \\
\text { discoloration, distortion and stickiness. }\end{array}$ & $\begin{array}{l}\text { Many kinds; radid reproduction; } \\
\text { brought into greenhouse in summer } \\
\text { through open vents or in winter on } \\
\text { new stock; } \\
\text { Excrete honeydew which blackens } \\
\text { leaves by promoting growth of black } \\
\text { mold. }\end{array}$ \\
\hline Ants & $\begin{array}{l}\text { Easily identified; red, brown to black } \\
\text { colored; usually in colonies. }\end{array}$ & $\begin{array}{l}\text { Indirectly responsible, they carry } \\
\text { aphids to upper soft parts of plants } \\
\text { and feed on honeydew. When nesting } \\
\text { in pots their tunneling will damage } \\
\text { roots. }\end{array}$ & $\begin{array}{l}\text { Spread aphids from plant to plant. } \\
\text { Carpenter ants usually larger and feed } \\
\text { primarily on spruce lumber. Wood } \\
\text { preservatives will prevent damage. }\end{array}$ \\
\hline Fungus gnats & $\begin{array}{l}\text { Tiny }(3 \mathrm{~mm} \text { ) black or grey flies in } \\
\text { greenhouse or on surface of soil; } \\
\text { larvae are tiny (up to } 4 \mathrm{~mm} \text { ), silvery } \\
\text { white and wormlike and live in the } \\
\text { soil; visible as wriggling forms when } \\
\text { soil is watered. }\end{array}$ & $\begin{array}{l}\text { Usually a nuisance only; sometimes } \\
\text { larvae will feed on tender young roots. }\end{array}$ & $\begin{array}{l}\text { Live mainly on decaying organic } \\
\text { matter such as peat moss; presence } \\
\text { often associated with use of } \\
\text { unpasteurized soil and with over } \\
\text { watering. }\end{array}$ \\
\hline $\begin{array}{l}\text { Cyclamen } \\
\text { mites }\end{array}$ & $\begin{array}{l}\text { Looks like a coating of dust on plant. } \\
\text { Are much smaller than common spider } \\
\text { mites. }\end{array}$ & $\begin{array}{l}\text { Leaves and stems twisted and brittle. } \\
\text { leaves eventually covered with small } \\
\text { scabs. Flowers may abort or loose } \\
\text { color. }\end{array}$ & $\begin{array}{l}\text { These mites also attack several other } \\
\text { species of plants. }\end{array}$ \\
\hline Leaf miners & $\begin{array}{l}\text { Small, light colored grubs that feed } \\
\text { between the upper and lower leaf } \\
\text { surfaces. }\end{array}$ & $\begin{array}{l}\text { Irregular, white pattern either long and } \\
\text { narrow or blotchy. }\end{array}$ & $\begin{array}{l}\text { Usually affects chrysanthemums or } \\
\text { cinerarias but may affect others. }\end{array}$ \\
\hline $\begin{array}{l}\text { Mealy bugs } \\
\text { and } \\
\text { Root mealy } \\
\text { bugs }\end{array}$ & $\begin{array}{l}\text { Looks like small pieces of white flurry } \\
\text { cotton; nesting occurs in leaf axlis; } \\
\text { individuals about } 4-5 \mathrm{~mm} \text { long; oval; } \\
\text { suck plant juices from underside of } \\
\text { leaves. }\end{array}$ & $\begin{array}{l}\text { Discoloration, distortion, weakening of } \\
\text { plant. }\end{array}$ & $\begin{array}{l}\text { Excrete a shiny honeydew on which } \\
\text { black mold may grow. }\end{array}$ \\
\hline
\end{tabular}




\section{TABLE 13. Continued}

\begin{tabular}{|c|c|c|c|}
\hline Nematodes & $\begin{array}{l}\text { Very minute, wormlike creatures one } \\
\text { species causes roots to swell to small } \\
\text { nodules. }\end{array}$ & $\begin{array}{l}\text { Roots are unable to absorb water and } \\
\text { nutrients so plants look unhealthy and } \\
\text { wilt for no apparent reason. }\end{array}$ & $\begin{array}{l}\text { Do not take cutting from lower } \\
\text { portions of an infested plant. }\end{array}$ \\
\hline Scale insects & $\begin{array}{l}\text { Oval, flattened, motionless, brown } \\
\text { shell-like objects (scales) about } 4 \mathrm{~mm} \\
\text { long on stems and leaves; } \\
\text { accompanied by translucent white, } \\
\text { very flat, small ( } 4 \mathrm{~mm} \text { ) insects almost } \\
\text { invisible on leaves (crawlers). }\end{array}$ & $\begin{array}{l}\text { Suck plant tissue causing discoloration } \\
\text { and general weakening }\end{array}$ & $\begin{array}{l}\text { The brown scale provides protection } \\
\text { for eggs of the scale insect; actual } \\
\text { feeding damage is done by crawlers } \\
\text { which hatch from the eggs. }\end{array}$ \\
\hline & $\begin{array}{l}\text { Soft bodies animal covered with } \\
\text { mucus; about } 7-8 \mathrm{~cm} \text { long; light brown } \\
\text { or grey. }\end{array}$ & $\begin{array}{l}\text { Slimy trails on soil or benches; leaves } \\
\text { partially or totally eaten. }\end{array}$ & $\begin{array}{l}\text { Presence can be discouraged by } \\
\text { removing weed growth in and around } \\
\text { greenhouses, reducing humidity and } \\
\text { increasing air circulation. }\end{array}$ \\
\hline Spider mites & $\begin{array}{l}\text { Very small, no bigger than a pinhead; } \\
\text { red or tan or with two black spots; } \\
\text { spins a fine web. }\end{array}$ & $\begin{array}{l}\text { Sucking of plant tissue to cause yellow } \\
\text { speckling of leaves progressing to } \\
\text { yellow motting and eventual browning. }\end{array}$ & $\begin{array}{l}\text { Very difficult to spot because of their } \\
\text { small size; webbing indicative of a } \\
\text { large infestation; for more information } \\
\text { see Control of Two-Spotted Spider } \\
\text { Mites (Agdex 620-2) }\end{array}$ \\
\hline Thrips & $\begin{array}{l}\text { Tiny insects, black or brown when } \\
\text { mature, and white, yellow or orange } \\
\text { when young, adults can fly; found on } \\
\text { leaves and flowers. }\end{array}$ & $\begin{array}{l}\text { Rasping of plant tissue causing } \\
\text { deformation and silvery streaks or } \\
\text { speckles. }\end{array}$ & $\begin{array}{l}\text { Tap plant over white paper to disclose } \\
\text { presence; usually difficult to find on } \\
\text { the plant unless numerous. }\end{array}$ \\
\hline Whiteflies & $\begin{array}{l}\text { Adult is a small ( } 3 \mathrm{~mm}) \text {, white winged, } \\
\text { easily visible "fly"; larvae light green. }\end{array}$ & $\begin{array}{l}\text { Suck plant tissue causing discoloration } \\
\text { and distortion. }\end{array}$ & $\begin{array}{l}\text { When infested plant is disturbed, } \\
\text { white flies will rise up in a cloud and } \\
\text { then resettle immediately; secretes } \\
\text { honeydew on which black mold may } \\
\text { grow. }\end{array}$ \\
\hline
\end{tabular}




\section{GREENHOUSE PLANTS}

The biggest problem a hobby greenhouse grower will have is deciding what NOT to grow. Consider the following points before you make your decision:

- Different plants require different temperatures to grow well. For example, warm season crops (cucumbers, melons, tomatoes) prefer a temperature range of $15^{\circ} \mathrm{C}$ to $27^{\circ} \mathrm{C}$. Cool season crops such as lettuce prefer a temperature range of $10^{\circ} \mathrm{C}$ to $15^{\circ} \mathrm{C}$. Whatever you decide to grow, find out the temperature requirements for germination, growth and flowering. Provision of proper growing conditions is important to successful greenhouse gardening.

- Light is also an important environmental factor for plant growth. Different plants have different requirements for light. Do not try to raise shade-loving foliage plants along with plants like tomatoes, roses or carnations, which require high-light conditions.

- To save on fuel costs, consider closing your greenhouse for part of the winter. For example, grow annual bedding plants and vegetable seedlings from February to June. Follow these crops with cucumbers, tomatoes or peppers during the summer and perhaps move in potted chrysanthemums for late fall bloom. After this crop is finished, close the house.

- Again, to reduce fuel costs, you can use your greenhouse in the winter only for carrying over dormant plants, such as fuchsias, geraniums, azaleas and chrysanthemums. Supply just enough heat to prevent temperature from falling below the freezing point in the greenhouse.

\section{Ornamentals}

Annual Bedding Plants - Preparations for planting annual bedding plants must be started in late February; however, all bedding plants should not be seeded on the same date. This is because each plant requires a different length of time from sowing to blooming. Adjustments may need to be made to suit the conditions of your particular greenhouse. Sowing the seed too early is a common mistake made in handling annuals.

Plastic or clay flower pots (with drainage holes) or flats may be used. A $9 \mathrm{~cm}$ pot normally holds a sufficient number of seedlings of any one kind for most home gardens, but a $13 \mathrm{~cm}$ pot may have to be used for large seeds. A good soil mix is made of 2 parts pasteurized loam, one part peat moss and one part sand. A soiless mix may also be used. Scatter the seeds thinly over the surface. Cover the seeds with growing mix to a depth twice the diameter of the seed. Very fine seeds need no cover.
After sowing, stand the containers in about $3 \mathrm{~cm}$ of water and let the water soak up from below. Cover the flats with polyethylene, glass or newspaper to help maintain even moisture and temperature conditions and protect from direct sun. Remove the cover as soon as the seeds germinate. Seeds of most annuals germinate readily at warm temperatures $\left(18^{\circ}-22^{\circ} \mathrm{C}\right)$. Some plants, however, prefer slightly cooler or slightly warmer temperatures.

These plants prefer cooler temperatures, $7^{\circ}-10^{\circ} \mathrm{C}$ :

$\begin{array}{lll}\text { Arctotis } & \text { Consolida } & \text { Iberis } \\ \text { Centaurea } & \text { Gypsophila } & \text { Nemesia }\end{array}$

Clarkia

These plants require warm temperatures, $21^{\circ}-27^{\circ} \mathrm{C}$ :

$\begin{array}{lll}\text { Amaranthus } & \text { Cobaea } & \text { Lobelia } \\ \text { Browallia } & \text { Dahlia } & \text { Nierembergia } \\ \text { Callistephus } & \text { Gaillardia } & \text { Petunia } \\ \text { Celosia } & \text { Helichrysum } & \text { Rudbeckia } \\ \text { Cleome } & \text { Impatiens } & \end{array}$

Transplant the tiny seedlings $5-8 \mathrm{~cm}$ apart as soon as the first true leaves appear (the second visible set of leaves). Do not wait until these leaves have fully developed or the plants will be set back when they are moved. Drop the temperature to $13^{\circ}-15^{\circ} \mathrm{C}$ after transplanting to provide for optimum plant growth. As the weather becomes warmer, expose the plants gradually to cooler temperatures 3 weeks before planting them outside in order to harden them off. Plants moved directly from the heat of the greenhouse to the garden are soft and are likely to wilt severely or die when set out. African violets (Saintpaulia)-African violets are easy to propagate and grow. Use a soil mixture with a large amount of compost or peat moss, such as 2 parts peat moss to 1 part potting loam and 1 part sharp sand or perlite. A uniform moisture level is important during growth; however, keep them on the drier side after blooming. Avoid splashing cold water on the leaves. A night temperature of $18^{\circ} \mathrm{C}$ and a daytime range of $22^{\circ}-24^{\circ} \mathrm{C}$ are preferred. Although they need shade during most of the year, provide maximum light during the winter months to improve flowering. Fertilize African violets regularly with a fertilizer higher in phosphorus than it is in nitrogen. Propagate named cultivars from leaf cuttings or crown divisions at any time. Propagate new cultivars from seed.

Bulbs (forced) - The two bulb groups are (1) tender tropical types, including amaryllis, lachenalia, tuberous begonias, clivia, crinium, eucharis, tuber roses, gloriosas, haemanthus, neomarcia, freesia, oxalis, callas, achimenes 
and gloxinias. These bulbous plants can be grown indoors all year round, although they go through a dormant period where the foliage dies down: (2) the hardy bulbs, including tulips, hyacinths, narcissus (or daffodil), and crocus. These plants are brought inside or bought in the fall and forced to bloom indoors during the winter months.

Select plump, sound bulbs free of blemishes and avoid very small ones. Bulbs are sometime planted in the fall, before the ground freezes. Store the dry bulbs in a cool, dark place until planting. Bulbs require a porous growing medium and will not thrive in a heavy, compact soil. All bulbs will do well in a good loam mixed with coarse builder's sand and peat moss or leaf mold. Special bulb fibre (composed of peat, charchoal and oyster shell) may be used in place of potting soil. If fibre is used, place a $2.5 \mathrm{~cm}$ layer of soil or sand in the bottom of the pot first.

Bulbs can be grown in any type of container. The roots are not long so the pot need not be deep. Pot diameter should be just large enough to hold all the bulbs without allowing them to touch each other or the sides of the pot. To pot, half-fill the container with sterile potting mixture or moist bulb fibre. Set the bulbs closely together on this layer, but do not allow them to touch. The exception to this rule is with hyacinths, narcissi and amaryllis bulbs, whose necks should protrude through the soil level. The material around the bulbs should be firmed just enough to give them support.

After planting, water the bulbs thoroughly and place them in a cool $\left(5^{\circ}-10^{\circ} \mathrm{C}\right)$, dark location, keeping the soil moist. When a strong root system is established and about 5 $\mathrm{cm}$ of top growth is visible, move them into full light at a temperature of about $18^{\circ}$ to $20^{\circ} \mathrm{C}$. The buds will then begin to open. Pay particular attention to water needs.

Daffodils, crocuses and muscari will develop stronger, healthier stems and flowers if they are kept at cooler temperatures, close to $15^{\circ} \mathrm{C}$. After blooming, the flowers will fade, and should be removed. Continue to water the plants while the foliage ripens. When the plant has died completely down, remove the bulbs and store them in a cool, dry place. Plant them outside in September. It is not advisable to try to force bulbs a second year, but they will flower outside in the following spring if properly ripened-off at the end of the forcing year.

Cacti and other Succulents - Succulents (which include cacti) are plants that have thick, fleshy stems or leaves. They will survive in less than ideal growing conditions; however, maximum sunlight and warmth $\left(21^{\circ}-24^{\circ} \mathrm{C}\right)$ are required for optimum growth.
Succulents should be watered until the upper $1 \mathrm{~cm}$ of soil feels completely dry because they are very susceptible to stem rot as a result of overwatering. A moist, stuffy atmosphere will also cause this problem, so ventilation must be adequate.

A porous and well-drained soil mixture is needed for these plants. The best combination is 1 part loam, 1 part peat moss and 2 parts coarse builder's sand.

Most succulents have a dormant period, usually during winter when light intensity is low. Careful observation is necessary to detect the signs of oncoming dormancy; growth slows and the plant may shrivel slightly. At the beginning of the resting period, gradually reduce water to about one light watering every one or two weeks, just enough to keep the soil from drying completely. Edema (tissues swollen with water) is not an uncommon occurance on cacti, particularly during the winter when light is low. To prevent this, avoid overwatering and do not allow soil temperature to rise above that of the surrounding air. When growth resumes, gradually increase watering again.

Succulents can be raised from seed, but their growth is slow. Bottom heat, shade and an even moisture supply are needed for seed germination. Cuttings root well. Take cuttings with a clean, sharp knife and let them dry in a warm, dry place until a callus or skin has formed over the cut surface. Shallowly insert the cutting into a propagating mix, such as coarse sand or half peat and half sand. Transplant soon after rooting. Protect cuttings from direct sunlight, keep the soils lightly moist, and give them bottom warmth. Ventilation is essential to prevent basal decay. Many cacti produce plantlets which can be removed and inserted in the rooting medium.

Christmas cacti and forest-growing tropical cacti require different treatment from that described above. Most of them require some shade during the hottest part of the year, and they should not be allowed to dry out, although less water is required after completion of summer growth. A good potting mix for these types of cacti is 1 part loam, 2 parts peat and 2 parts coarse builder's sand.

Geraniums - Geraniums require high light intensities to grow well. They can be grown from cuttings or seed at anytime. Also, geraniums grown outdoors can be dug up and potted before winter and carried over in a cool greenhouse until spring. It is possible to take cuttings in late August to produce stock for planting indoors next spring. After rooting the cutting, pot them in $10 \mathrm{~cm}$ pots. Geraniums are very susceptible to viral, fungal and physiological disorders. If foliage becomes spotted or mottled, destroy the plants and start again with clean stock. Avoid overwatering. 
The day temperature for ideal growth is $19^{\circ}-21^{\circ} \mathrm{C}$ and the night temperature should be $10^{\circ}-13^{\circ} \mathrm{C}$. Use soluble fertilizers, such as 20-20-20, once every two weeks from March through October at a rate of $5 \mathrm{~g}$ in $1 \mathrm{~L}$ of water. Reduce fertilization in the winter.

Gloxinia - Gloxinias belong to the same plant family as African violets and prefer the same environmental conditions. Plants grown from seeds will take six months to flower, while tubers are much quicker.

For the growing medium, use two parts soil, 2 parts peat moss and 1 part sand. Good commercial mixes are also available. After flowering the plants should be kept drier and cooler to induce dormacy. The tops will die down and just enough moisture should be applied to prevent the tubers from shrivelling. Tubers can be allowed to either rest where they are or stored out of the way in closed plastic bags filled with barely damp peat moss or vermiculite. Repot gloxinias when new shoots start to appear (usually in 2-4 months). Propagate the continuously blooming plants from leaf cuttings or from seeds at anytime.

Orchids - Orchids are an interesting group of plants, which in their natural habitat grow on trees and absorb most of their nutrients from particles of organic matter carried to their large, fleshy roots by rain. The white, corky layer on the roots absorbs moisture readily. The leaves are usually thick and fleshy, helping to carry the plant through periods of drought.

Most orchids like a humid atmosphere, but temperature requirements vary. Some varieties like a night temperature of $15^{\circ} \mathrm{C}$, with $21^{\circ} \mathrm{C}$ in the day time. The heat-loving types require a minimum night temperature of $21^{\circ} \mathrm{C}$.

Most orchids are not grown in soil but are potted in ordinary clay pots, using chips of fir bark or osmunda fibre. Occasional feeding with a weak fertilizer solution may be required.

Tropical Foliage Plants - This category of plants require warm temperatures, shade and a moist atmosphere. The night temperature should not be below $16^{\circ} \mathrm{C}$. There is an endless variety of tropical foliage plants that can be easily grown. Some of the commonly known types are the philodendrons, rex begonias, tropical ferns, dracaena and the green or variegated rubber plants.

Most tropical plants require a well-drained soil mix containing plenty of peat moss. They generally can be propagated easily from cuttings and should be fertilized regularly with very dilute solutions of a complete fertilizer containing slightly more nitrogen than phosphorus.

\section{Vegetables and Fruit}

Cucumbers - Since cucumbers require fairly high light intensities, they are best started in spring so that they receive the bright summer sunlight during the period of fruit production. If seed is started in February, placing the transplants into the greenhouse beds can begin in about 3 weeks and picking in about another 6 weeks. If you plan to grow cucumbers after bedding plants, sow them around mid-May and transplant around June 7.

It is advisable to use your valuable greenhouse space to grow seedless long English cucumbers, which do not grow well outside. Recommended cultivars include Farbio, Corona, Pandex, Toska and Sandra. Cucumbers have their sexual part separated into female and male flowers (see figure 39).

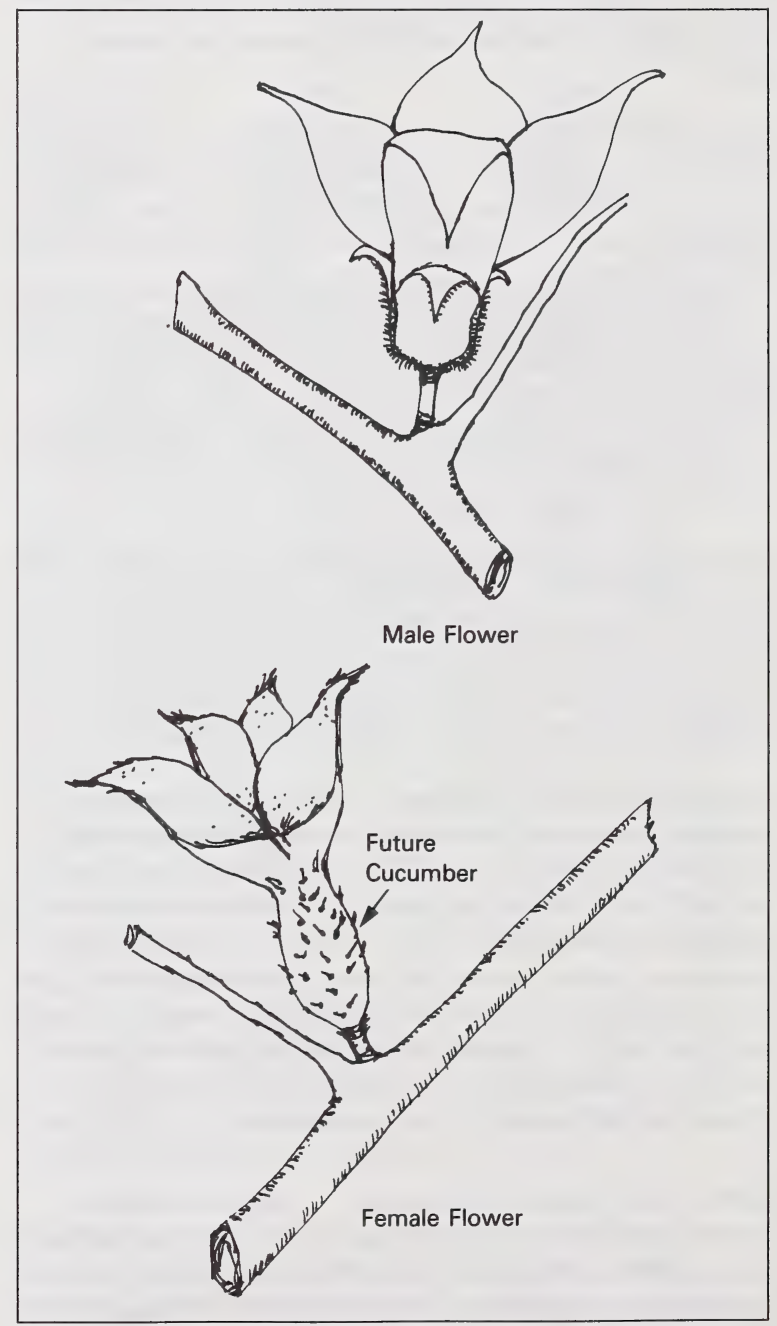

Figure 39. Females and male cucumber flowers 
The cultivars recommended produce mainly female flowers, which can set fruit without pollination, and thus the fruit is seedless. Any male flowers should be removed because if pollination occurs seed will form, the fruit will become misshapen and a bitter taste will develop.

Seeds should be started in a porous mix at a temperature of $28^{\circ} \mathrm{C}$. Transplanting to $10-12 \mathrm{~cm}$ pots should be done when the seed leaves have fully expanded (about 4-5 days after germination.) Because cucumbers are very susceptible to transplant shock, it is best to transplant them into peat pots, which do not have to be removed before transplanting. Transplant cucumbers into beds when plants are $15-20 \mathrm{~cm}$ tall, allowing 0.7 to 0.8 $\mathrm{m} /$ plant. Training the plants to grow upwards must begin when the plants are small. To do this, run two wires over the row, about $2.2-2.5 \mathrm{~m}$ above ground. Space the wires so that each wire is about $30-40 \mathrm{~cm}$ to either side of the row. A string is then wound loosely around the stem of each side (see figure 40). This allows light to enter and the fruit to hang away from the stem.

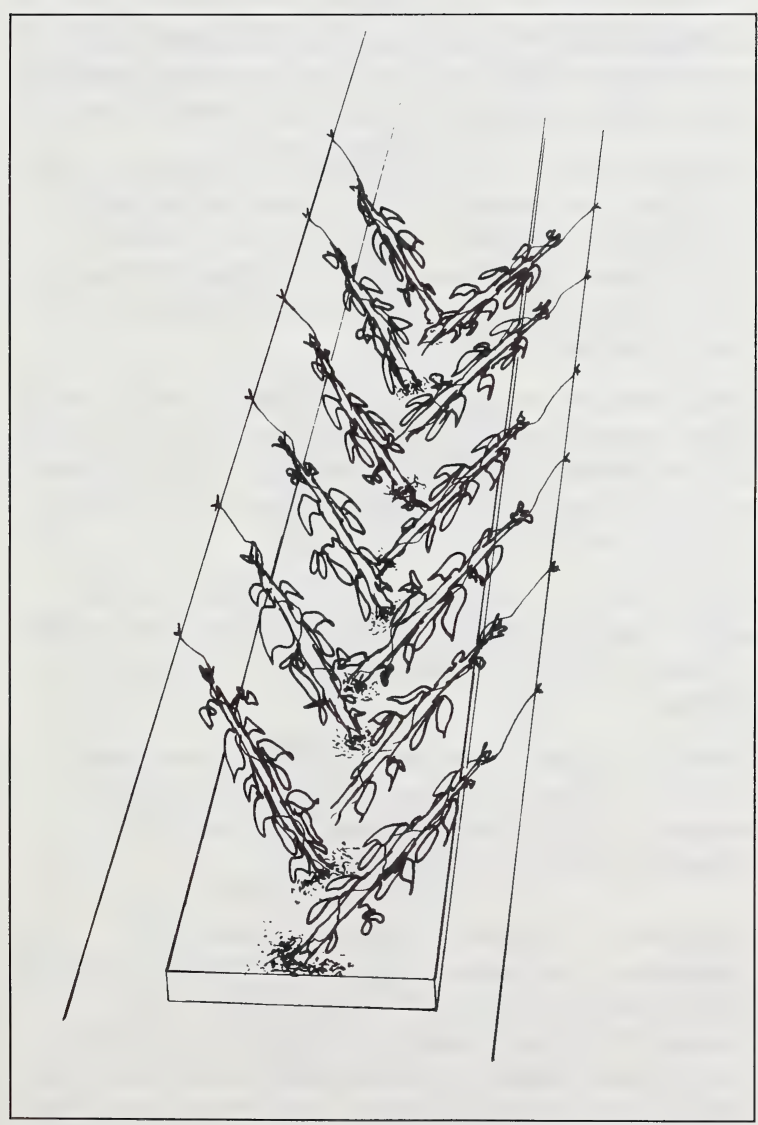

Figure 40. Training cucumbers - perspective view etc.
After transplanting cucumbers, keep the temperature at $20^{\circ} \mathrm{C}$ during the night and $22^{\circ}-25^{\circ} \mathrm{C}$ during the day. When fruit begins to develop, add $12-0-44$ or $15.5-0-0$ at the rate of $1 \mathrm{~kg} / 100 \mathrm{~m}^{2}$.

Cucumbers need to be pruned for good fruit production. A good pruning method is outlined in the following steps (see figure 41).

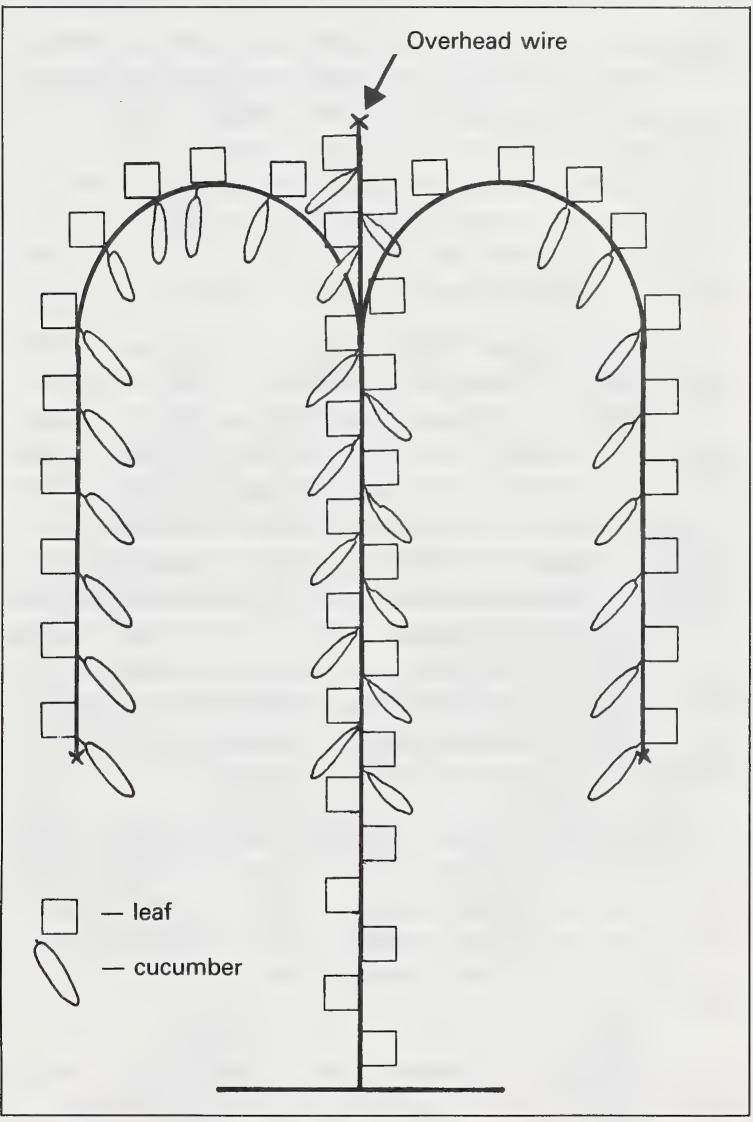

Figure 41. Pruning cucumbers

- Remove the growing point of the first leaf above the wire.

- Remove all side shoots except for two near the top of the plant.

- Train these two laterals over the wire and allow them to grow down. Remove growing tips $1 \mathrm{~m}$ from the ground.

Harvest cucumbers frequently because they develop quickly. The plants can be removed after one crop, or new laterals can be trained up from the main stem to replace the original laterals and extend production. Cucumbers are very susceptible to spider mite infestation. 
Eggplant - This much ignored plant can be easily grown in the home greenhouse in Alberta. It is naturally slow growing and, therefore, must be given an early start. It is very sensitive to low temperature. Plant growth is always checked and often permanently stunted if temperature falls below $10^{\circ} \mathrm{C}$.

Lettuce - Leaf and buttercrunch lettuce are easily grown in the greenhouse year-round. Lettuce prefers both cool soil and cool air temperatures and, therefore, does not always fit into the greenhouse program when other plants are being grown. If conditions are too warm, the lettuce will be bitter and go to seed quickly.

Recommended leaf cultivars are Waldmans and Grand Rapids, and recommended butterhead cultivars are Ostinata, Deci Minor and White Boston. Many crisphead cultivars can also be grown.

Sow seeds in a light artificial mix in a tray or pot. After germination (1-2 weeks) transfer them to pots or flats with soil mix. Allow them to grow for another 2 weeks during the summer or another 3 weeks during the winter, then transplant directly to a soil or soiless mix at a spacing of about $20 \times 20 \mathrm{~cm}$. Leaf lettuce requires a night temperature of $10^{\circ}-13^{\circ} \mathrm{C}$ and a day temperature of $13^{\circ}-21^{\circ} \mathrm{C}$. Butterhead types require a night temperature of $18^{\circ} \mathrm{C}$ and a day temperature of $17^{\circ} 19^{\circ} \mathrm{C}$ on dull days and $21^{\circ}-24^{\circ} \mathrm{C}$ on bright days. The above-mentioned cultivars will be ready for harvest within $3-4$ weeks during the summer or 5-6 weeks if grown during the winter. Crisphead cultivars will take a longer time.

Lettuce is a poor feeder, so a high level of nutrition must be maintained. If a good level of nutrition already exists, $1.5 \mathrm{~kg}$ of $20-20-20$ per $100 \mathrm{~m}^{2}$ worked into the soil before planting should be sufficient. If the color of leaves is pale, $2 \mathrm{~kg} / 100 \mathrm{~m}^{2}$ of ammonium nitrate (34-0-0) should be used.

Botrytis grey mold is the most serious disease problem of lettuce. Avoid watering from the top or grow only leaf lettuce. Lettuce does not store well, so the best practice is to stagger small plantings over time so that all that is harvested can be used fresh.

Onions - Onions are seldom considered a greenhouse crop, but they do respond well to greenhouse culture. Soil conditions are very important. Soil should be loose, welldrained, warm, highly retentive of moisture and well supplied with humus. Since onions are shallow rooted, both moisture and fertilizer quickly drop below the root zone unless they are often replaced at the soil surface. For this reason, a small amount of fertilizer applied frequently is much more effective than a larger amount mixed through all of the soil. Onions may be started from seeds or sets, but seed onions do not usually reach a size suitable for dry storage in the same year.

Peppers - Peppers do best in well-drained, moist, light, warm soil containing large amounts of humus. Because the early culture of both peppers and tomatoes is the same, they can be grown together. Since the peppers do not need as much fertilizer as tomatoes, it is wise to set all of the pepper plants in a group at one end of a bench or bed to avoid overfertilization. Peppers should be pollinated in the same manner as tomatoes (see section on tomatoes page ). Since peppers are naturally determinate, and thus do not form long vines, they are suited to bench culture. Peppers are relatively free of disease as long as there is good ventilation and air circulation around the plant.

Radishes - These are normally a garden crop, but a few feet or rows can be planted between other crops in the greenhouse. Environmental conditions suitable for lettuce are also suitable for radishes.

Strawberries - Strawberries are not commercially grown in greenhouses in Alberta for economic reasons. In hobby greenhouses, however, they are worthy of trial.

Strawberries prefer a well-drained growth medium. Mixes containing slow release fertilizers should not be used because they are likely to cause foliar burn. Diluted concentrations of fertilizer should be applied 4-6 weeks after planting. Regular leachings should be done to prevent soluble salt build-up.

Strawberries require a great deal of water. Drought results in leaf marginal burn. A night temperature of $17^{\circ} \mathrm{C}$ and a day temperature of $20^{\circ}-25^{\circ} \mathrm{C}$ are ideal. Hand pollination or shaking the infloresence may be necessary to ensure pollination and fruit set.

No cultivars have been tested for greenhouse forcing under Alberta conditions. Try the following: June bearer - Protem, Senga, Sengana; Everbearer - Ogallala Jubilee.

Powdery mildew and spider mites are the main pest problems. A preventative spray program for powdery mildew should be developed, once it appears it is extremely difficult to eradicate.

\section{Tomatoes - Tomatoes should be seeded and} germinated in the same way as bedding plants. Tomatoes can be seeded as early as the beginning of April; however, if you are growing bedding plants and have limited space, seeding should be delayed until May 1. Try using a greenhouse rather than a field cultivar since they have been genetically selected for superior growth under 
greenhouse conditions. Greenhouse cultivars include Vendor, Tropic, Michigan, and Ontario hybrids.

Once the first true leaves appear, transplant the seedlings into $7.5 \mathrm{~cm}$ peat or plastic pots and grow them until they are ready to set out in ground beds or to transplant to larger pots. If seeding was done about May 1 , the seedlings should be ready to transplant about June 1 . When the plants are $15 \mathrm{~cm}$ high they will be ready to set out allowing 0.3-0.4 $\mathrm{m}$ per plant. Temperatures of $21^{\circ}-24^{\circ} \mathrm{C}$ during the day and $16^{\circ}-18^{\circ} \mathrm{C}$ at night are desirable.

Greenhouse tomatoes are usually pruned to a single stem by removing lateral shoots from leaf axils before they are $2 \mathrm{~cm}$ long (see figure 42). Lateral shoots and fruit clusters alternate along the length of the stem. The plants are supported by tying binder-twine loosely around the base of the plant and tying the other end to overhead supporting wires, about 2- $2.5 \mathrm{~m}$ above ground. The plants are kept upright by twisting them loosely around the twine as they grow. The growing tip is usually broken off when it reaches the overhead wire, and after all fruit has been harvested the plants are removed. If the growing tip is left, however, the plant will grow into a long vine.

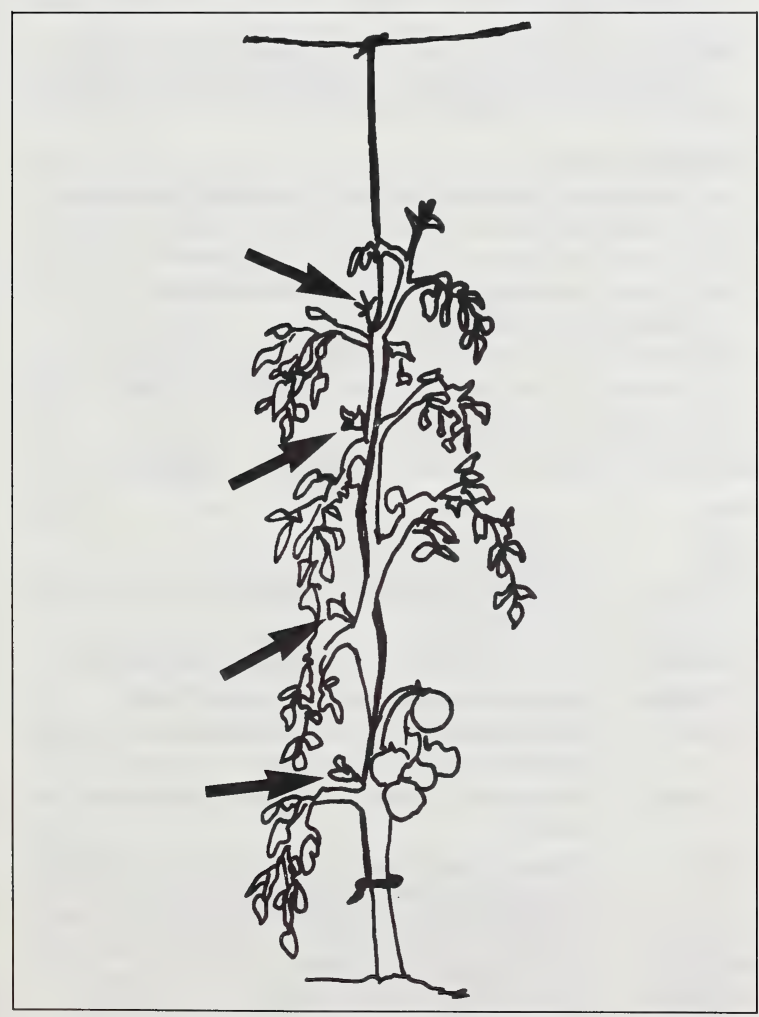

Figure 42. Pruning and training tomatoes
Greenhouse tomatoes need to be artificially pollinated to set fruit. The supporting wire can be tapped lightly with a stick or individual flower clusters can be vibrated with an electric toothbrush to ensure the spread of pollen by hand, using a paintbrush or cotton swab. Pollination should be done about 3 times per week, between the hours of 11 a.m. and 2 p.m. Pollen is shed more abundantly on bright sunny days when temperatures exceed $21^{\circ} \mathrm{C}$.

Do not over-fertilize tomatoes. Establish good soil fertility conditions initially in the bed by applying $21-0-0$ or 10-30-10 as needed (as determined by soil test). Later on, when fruit is developing, add 15.5-0-0 at the rate of 1.25 $\mathrm{kg} / 100 \mathrm{~m}^{2}$. If soilless mixes are used, apply $20-20-20$ at a rate of $2.5 \mathrm{~kg} / 200 \mathrm{~L}$ per $100 \mathrm{~m}^{2}$.

\section{Propagation from Cuttings}

Cuttings from most of your plants will root easily, provided they are given bottom heat and a moist temperature. A soil-heating cable is the most convenient way to provide heat. A single length of 250 watt heating cable is sufficient for about $2.3 \mathrm{~m}$ of bed area. The cable should be first covered with $5 \mathrm{~cm}$ of sand. $10 \mathrm{~cm}$ of rooting medium should be placed over the sand and a tight-fitting glass or plastic cover placed over the cuttings with not more than $15 \mathrm{~cm}$ of air space between the surface of the rooting medium and the glass. Shade cuttings from direct sun. Cuttings will root more rapidly if they are first dipped in rooting hormone. If the area required for cuttings is very small, a light bulb placed in a flower pot or a tin can under the flats of cuttings will provide enough heat for a flat or two of cuttings (see figure 43).

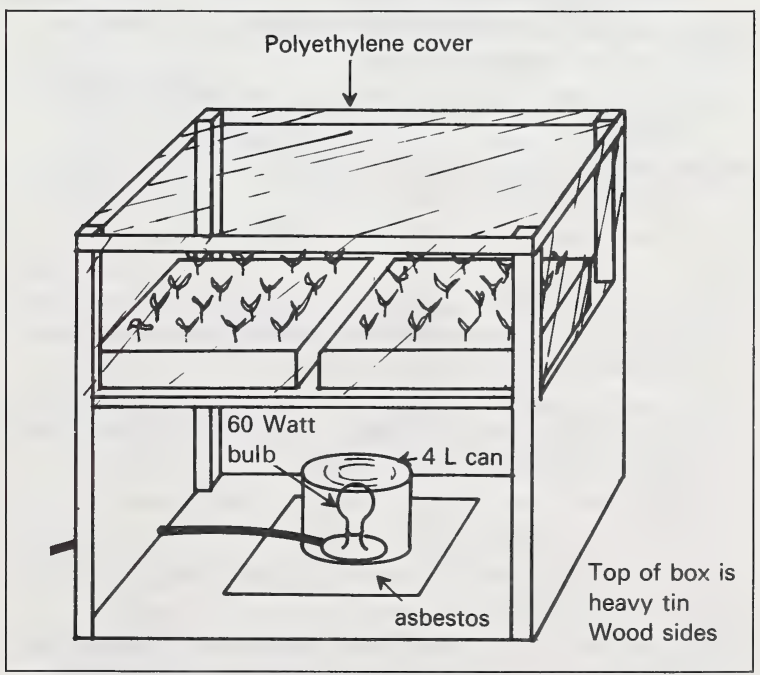

Figure 43. Propagating case 


\section{Appendix 1. Greenhouse References}

\section{General Production \& Management}

Greenhouse Management. 1978. J.J. Hanan, W.D. Holley and K.L. Goldsberry, Springer-Verlag, New York Inc., 175-5th Ave., New York, NY, 10010. $530 \mathrm{pp}$

Greenhouse Management. 2nd ed. 1983. R.W. Lanhans, Halcyon Press of Ithaca, Ithaca, NY. 270 pp.

Greenhouse Management for Flower and Plant Production. 2nd ed. 1980. K.S. Nelson, Interstate Printers \& Publishers Inc., Danville, IL. $252 \mathrm{pp}$

Greenhouse Operation and Management. 3rd. ed. 1985 Paul V. Nelson, Reston Publishing, Reston, VA, 22090. 518 pp.

The Commercial Greenhouse. 1981. J.W. Boodley. Delmar Publications Inc., 2 Computer Drive W., P.O. Box 15015, Albany, NY, 12212. $568 \mathrm{pp}$.

The Commercial Greenhouse Handbook. 1981. J.W. Boodley, Van Norstrand Reinhold. 576 pp.

The Greenhouse Environment. 1977. J.W. Mastalerz. Wiley \& Sons. $629 \mathrm{pp}$

Commercial Flower Forcing. 8th ed. 1979. Laurie, Diplinger and Nelson. McGraw-Hill Book Co. 438 pp.

The Ball Red Book. 14th ed. 1984. V. Ball (ed.) George J. Ball. Reston Publishing. Reston, VA. 22090. 720 pp.

Introduction to Floriculture. 1980. R.A. Larson (ed.) Academic Press Inc. $607 \mathrm{pp}$.

\section{Greenhouse Vegetable and Soilless Culture Publications}

Cucumber Diseases. Agriculture Canada Pub. 1684, W.R. Jarvis and V.W. Nuttall, Research Station, Harrow. Available from Information Services, Agriculture Canada, Ottawa, K1A 0C7 or OMAF County Office.

Tomato Diseases. Agriculture Canada Pub. 1479. pp. Availability same as above.

Greenhouse Vegetable Production Recommendations. OMAF Pub $365,37 \mathrm{pp}$. Available from OMAF County Offices or Communications Branch, Toronto.

Cucumbers. (Grower Guide 15) 1981. Grower Books, 50 Doughty St., London, England, WC IN 2CP.

Lettuce Under Glass. (Grower Guide 21) 19 pp. Grower Books, London.

Peppers and Aubergines. (Grower Guide 3) 1981. Denis Smith. Grower Books, London. 91 pp. \$15.

Tomato Management. (Grower Guide 15) 1981. Grower Books, London. \$15.

Greenhouse Tomatoes-Diseases and Insect Control. Bulletin 674 The Publications Office, Ohio State University, 2120 Fyffe Road, Columbus, OH, 43210-1099. \$3.50 U.S.

Greenhouse Cucumbers-Diseases and Insect Control. Bulletin 718 The Publications Office, Ohio State University, 2120 Fyffe Road, Columbus, OH, 43210-1099. \$3.50 U.S.

Vegetables Under Glass. (Grower Guide 26) 1982. Grower Books, 50 Doughty Str., London, England. 77 pp.

Tomatoes in Peat. (Grower Guide) 1981. Grower Books, 50 Doughty St., London, England.

Bag Culture Production of Greenhouse Tomatoes. Ohio Agricultural Research and Development Centre, Wooster, OH. 44691. No charge for single copies.
Greenhouse Tomatoes, Lettuce and Cucumbers. 1979. S.H. Wittmer and S. Honma. The Michigan State University Press, East Lansing, MI. 225 pp. \$15. U.S.

The U.K. Tomato Manual. 1981. H.G. Dingham (ed.). Grower Books, 50 Doughty St., London, England. 223 pp. \$54.

ABC of NFT. 1979. A. Cooper. Grower Books, 50 Doughty St., London, England. \$16. U.S.

Commercial Applications of NFT. 1982. Grower Books, 50 Doughty St., London, England.

Advanced Guide to Hydroponics. 1980. J.S. Douglas. Pelham Books, 52 Bedford Square, London, England, WC IB3EF. 333 pp. \$20. U.S.

Hydroponics Food Production. 1981. H.M. Resh. Woodbridge Press Publishing Company, Santa Barbara, CA, 9311. 336 pp. \$25. U.S.

Hydroponics Worldwide: State of the Art in Soilless Crop Production. 1985. International Centre for Special Studies, 400 Hobron Lane, Suite 3502, Honolulu, HA, 96815-1209. \$40. U.S.

Soilless Cultivation and Its Application to Commercial Horticultural Crop Production. (FAO) Unipub, Xerox Publishing Co., 1180 Ave. of Americas, New York, NY, 10036.

Growing Plants Without Soil. 120 pp. 1982. Published by EP Publishing England. Distributed by Grower Books, 50 Doughty St., London, England.

Master Guide to Planning Profitable Hydroponic and SC̀EA Operations Worldwide. 1986. International Center for Special Studies 400 Hobron Lane, Suite 3502, Honolulu, Hawaii, 96815-1209. \$50. U.S

Hydroponics: A Guide to Soilless Culture Systems, (ed.). January, 1987. Mirza Mohyuddin, Alberta Tree Nursery and Horticulture Centre, R.R. 6, Edmonton, Alberta, T5B 4K3

\section{Solar Greenhouses}

Solar Greenhouses for the Home. 1985. Cooperative Extension Northeast Regional Agricultural Engineering Service. University of Connecticut, Storrs, CT. 06268. U.S.A., 1985, \$4. U.S.

Energy Conservation and Solar Heating for Greenhouse. Availability same as above.

University of Alberta Home Gardening Course. Book Four Controlled Environment. University of Alberta, Faculty of Extension, Corbett Hall Edmonton, Alberta, T6G 2 G4.

\section{Reading Material Available From Alberta Agriculture}

Agdex

$200 / 01$

FS 200/15-1 Sanitation and Disease Control Recommendations for Greenhouses

FS 200/23-1 Wood Preservatives for Home and Horticultural Use

FS 200/641-1 Herbicide Injury to Yard and Garden Plants

275/15-1 Soilless Culture of Commercial Greenhouse Tomatoes AC 1460

FS 270/621-1 Susceptibility of Some Ornamental Plants to Pesticide Injury

275/16-1 Nursery Propagation of Woody and Herbaceous Perennials for the Prairie Provinces AC 1733

FS 285/18-1 House Plants - Terrariums

FS 285/20-1 Easy to Grow House Plants

FS 285/20-2 General Care of House Plants

FS 285/20-3 House Plants - Lighting 
FS 285/20-4

FS $285 / 20-5$

FS 285/20-6

FS 285/20-7

FS 285/20-8

FS 285/20-9

FS 285/20-10

FS 285/20-11

FS 285/20-12

FS 285/30-1

FS 285/520-1

FS 285/541-1

FS 285/636-1

285/20-13

FS 518-7

FS 562-1

FS 731-1

FS $753-2$
FS 285/626-1

House Plants - Watering

House Plants - Humidity

House Plants - Repotting

House Plants - Propagation

House Plants - Artificial Lights

House Plants - Forcing Bulbs

House Plants - Gift Plants

House Plants - Cacti and Succulents

House Plants - Problems: Symptoms and Causes

House Plants - List of Species

House Plants - Soil

House Plants - Fertilizer

House Plants - Insects and Related Pests

House Plants - Disease

Care of Foliage Plants AC 1732

Diagnosis and Prevention of Salinity in Commercial Greenhouse Soils

Guidelines for Irrigation Water Quality

Greenhouse Heating Requirements: Calculating Heat

Loss

Chemical Injection in Irrigation Systems

\section{Reference Texts by Crops}

\section{Azaleas}

Azaleas. 1980. R.A. Larson. p.238-260. In: R.A. Larson(ed.), Introduction to Floriculture. Academic Press. 607 pp. \$33. U.S

Growing Azaleas Commercially. 1975. A.M. Dofranek and R.A. Larson. Agricultural and Natural Resources. Paperback. 108 pp. $\$ 7.50$ U.S.

Growing Azaleas. Cooperative Extension, United States Dept. of Agriculture, University of California, Berkeley, CA, 94720.

\section{Bedding Plants}

Bedding Plants. 1980. W.H. Carlson and E.M. Rowley. p. 479-522. In: R.A. Larson (ed.) Introduction to Floriculture. Academic Press. 607 pp. \$33. U.S. BPI Conference Proceedings, Bedding Plants Inc., Box 286, Okemos, MI, 48864.

Guide to Commercial Production and Marketing of Bedding Plants. A.M. Armitage, et. al. 1982. Dept. of Horticulture, University of Georgia, Athens, GA, 30602.

Park's Success with Seeds. 1978. Ann Reilly. George W. Park Seed Co. Inc., Greenwood, S.C. 364 pp. $\$ 12.95$ U.S.

Penn State Bedding Plants Manual. 3rd ed. 1985. Price not established at this time. Write: Pennsylvania Flower Growers, 102 Tyson Bldg., Pennsylvania State University, University Park, PA, 16802.

Tips on Growing Bedding Plants. Office of Information, College of Agriculture and Home Economics, The Ohio State University, 2120 Fyffe Rd., Columbus, OH, 43210. 26 pp. \$1.50 U.S. plus postage 54 cents.

\section{Bulbs}

Bulbous Plants. 1980. A. De Hertogh. pp. 217-235. In: R.A. Larson (ed.). Introduction to Floriculture. Academic Press. 607 pp.

Holland Bulb Forcers Guide. 1985. A.A. De Hertogh. Netherlands Flowerbulb Information Center, 250 West 57th St., Suite 629, New York, NY, 10019.

Holland Bulb Growers Guide 1985. Availability same as above.
The Growth of Bulbs: Applied Aspects of the Physiology of Ornamental Bulbous Crop Plants. 1972. A.R. Rees. Academic Press. 309 pp.

Freesias, (Grower Guide No. 1). 1979. Denis Smith. Grower Books. 80 pp. \$12. U.S.

\section{Carnations}

Carnations. 1980. S.T. Bessemer. p. 49-79. In: R.A. Larson (ed.). Introduction to Floriculture. Academic Press. 607 pp. \$33. U.S.

Carnations, A Manual of the Culture of Insects and Diseases, and Economics of Carnations. 1961. R.W. Langhans. Distribution Center-C, Cornell University. 107 pp., 7 Research Park, Ithaca, NY, 14850

Carnation Production. 1963. W.D. Holley and R. Baker. Wm. C. Brown Co. Inc.

\section{Chrysanthemums}

Crysanthemums. A Manual of the Culture, Diseases and Insects and Economics of Chrysanthemums. 1964. R.W. Langhans (ed.). Distribution Center-C, Cornell University. 185 pp., 7 Research Park, Ithaca, NY, 14850

Chrysanthemums-Year Round Growing. Barrie Machin \& Nigel Scopes (1978). Blandford Press Ltd., Link House, West Street, Poole, Dorset.

Cut Chrysanthemums. 1980. A.M. Lofranek. P. 5-45. In: R.A. Larson (ed.), Introduction to Floriculture. Academic Press. 607 pp. \$33. U.S.

Nutritional Disorders in Chrysanthemums. 1980. Unipub (A Xerox Publishing Co.). 42 pp. Paperback. \$15.25 U.S.

Pot Mums. 1980. G.D. Crater. p. 263-285. In: R.A. Larson (ed.). Introduction to Floriculture. Academic Press. 607 pp. \$33. U.S.

\section{Easter Lilies}

Easter Lilies. 1980. H.F. Wilkins. p. 329-352. In: R.A. Larson (ed.). Introduction to Floriculture. Academic Press. 607 pp. \$33. U.S.

Easter Lilies: The Culture, Diseases, Insects and Economics of Easter Lilies. 1967. D.C. Kiplinger and R.W. Langhans (ed.). Distribution Center-C, 7 Research Park, Cornell University, Ithaca, NY, 14850. (607) 256-2080. 158 pp. \$4. U.S.

\section{Foliage Plants}

A Pictorial Atlas of Foliage Plant Problems. 1983. R.W. Henley. Florida Foliage Association, P.I. Box Y, Apoka, FL, 32704.

Foliage Plant Production. 1981. J.N. Joiner. Prentice-Hall. 608 pp. $\$ 32.95$ U.S.

\section{Geraniums}

Geraniums III. A Penn State Manual. 3rd ed. 1982. J.W. Mastalerz \& E.J. Holcomb (ed.). Pennsylvania Flower Growers, 102 Tyson Bldg., The Penn State University, University Park, PA, 16802 410 pp. \$15. U.S

Cornell Geranium Guidelines for New York State. 1985. Cornell Distribution Center, 7 Research Park, Ithaca, NY, 14850. \$1.00 U.S.

\section{Gladiolus}

Gladiolus. 1980. G.J. Wilfret. p. 166-181. In: R.A. Larson (ed.). Introduction to Floriculture. Academic Press. 607 pp. \$33. U.S.

How to Grow Glorius Gladiolus. 1980. Published by North American Gladiolus Council, Publications Department, 8524 Vollmert Ave., Baltimore, MD, 21236. Paperback. $\$ 2.50$ U.S. 


\section{Gloxinia}

The Gloxinia Growers Manual. Earl J. Small Growers Inc. 6901-49th Street North, Pennellas Park, F., 33565.

\section{Poinsettia}

Commercial Poinsettia Production. 1978. R.A. Larson (ed.) Department of Horticultural Sciences, N.C. State University, Raleigh, NC, 27695-7609. 44 pp. \$2.50 U.S.

Poinsettias. 1980. J.B. Shanks. p. 303-326. In: R.A. Larson (ed.). Introduction to Floriculture. Academic Press. 607 pp. \$33. U.S

The Poinsettia Manual. 1971. Paul Ecke Jr. and O.A. Matkin (ed.). Paul Ecke Poinsettias, Encinitas, CA, 92024. 205 pp. \$10. U.S

\section{Reiger Begonias}

Mikkelsens Inc., Box 1536, Ashtabula, OH, 48004

\section{Greenhouse Roses}

Compendium of Rose Diseases. 1983. R.K. Horst (ed.). The American Phytopathological Society, 3340 Pilot Knob Road, St. Paul, MN, 55121. pp. 50

Greenhouse Roses: Diagnostic and Remedy of Nutritional Disorders J.W. White (ed.). Roses Inc., 1152 Haslett Road, Haslett, MI, 48840. $46 \mathrm{pp}$

Roses. 1980. R.F. Hase,. P. 83-105. In: R.A. Larson (ed.). Introduction to Floriculture. Academic Press. 607 pp. \$33. U.S. Roses. A Manual on the Culture, Management, Diseases, Insects, Econ omics and Breeding of Greenhouse Roses. 1969. J.W

Mastalerz and R.W. Langhans (ed.). Write: Distribution Center-C, 7 Research Park, Cornell University, Ithaca, NY, 14583.

Roses Under Glass. (Grower Guide No. 9). 1981. Grower Books. 78 pp. \$15. U.S.

\section{Snapdragons}

Snapdragons. 1980. M.N. Rogers. P. 108-131. In: R.A. Larson (ed.) Introduction to Floriculture. Academic Press. 607 pp. \$33. U.S

Snapdragons: A Manual on the Culture, Insects and Diseases, and Economics of Snapdragons. 1962. R.W. Langhans (ed.). Write Distribution Center-C, 7 Research Park, Cornell University, Ithaca, NY, 14850. (607) 256-2080. 93 pp

Evaluation and Scheduling of Snapdragon Cultivars. 1984. K.C Sanderson \& W.C. Martin. Bulletin 468. Alabama Agriculture Experiment Station, Auburn University, Auburn, AL, 36830

\section{Specific Production Topic Bulletins}

Energy Conservation in Ontario Greenhouses. OMAF Pub. 65, 24 pp. Available from OMAF County offices or Communications Branch, Toronto

Energy Conservation for Commercial Greenhouses. Cornell Distribution Center, 7 Research Park, Ithaca, NY, 14850. \$4. U.S

Conserving Energy in Ohio Greenhouses. 1979. Publications Office, The Cooperative Extension Service, Ohio State University, 2120 Fyffe Rd., Columbus, OH. $\$ 2.50$ U.S

Greenhouses. OMAF Pub. 40. Revised 1985. Available from OMAF County offices or Communications Branch, Toronto.

Using Carbon Dioxide in Greenhouses. OMAF factsheet 29027 Availability same as above.

Seed Propagated Free Flowering Geraniums. OMAF factsheet 29515. Availability same as above.

Commercial Applications of Supplementary Lighting in Greenhouses and Supplementary Lighting in Commercial Greenhouses.
OMAF factsheet 290717. Availability same as above. Air Pollution Problems in Greenhouses. OMAF factsheet 290922. Availability same as above.

Greenhouse Gerbera Production. OMAF factsheet 29515. Availability same as above.

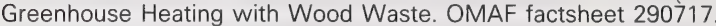
Availability same as above

\section{Trade Magazines}

Canadian Florist. Horticulture Publications Ltd., 1090 Aerowood Drive, Unit 1, Mississauga, ON, L4W 1 Y5

Florida Foliage Magazine. 114 E. Fifth St., Suite B, Apoka, FL, 32703.

Florist Review. Florist Publishing Co., 111 N. Canal St., Suite 545, Chicago, IL, 60606

Greenhouse Canada. 222 Argyle Ave., Delhi, Ontario, N4B 2Y2

Greenhouse Grower. Meister Publishing Co., 37841 Euclid Ave., Willoughby, $\mathrm{OH}, 44094$

Greenhouse Manager. Branch-Smith Publishing, P.O. Box 1868, Fort Worth, TX, 76101. Grower Talks. Geo. J. Ball Co., 250 Town Rd., P.O. Box 501, West Chicago, IL, 60185

Bloemisterij (weekly Dutch Floriculture Magazine). co C. Misset bv. ljsselkade 32, 7001 AP Doetinchen, The Netherlands.

Tuindery (biweekly Dutch Vegetable magazine), co Misset bv., ljsselkade 32, 7001 AP Doetinchem, The Netherlands.

\section{Courses}

University of Alberta, Home Gardening Courses, Faculty of Extension, Corbett Hall, Edmonton, Alberta, T6C 2G4

Alberta Agriculture, 7000-113 St., Edmonton, Alberta, T6H 5T6

Athabasca University, Box 1000, Athabasca, Alberta, TOG 2R0 Continuing Education Office, Olds College, Olds, Alberta, TOM 1P0 Lakeland College, Vermilion, Alberta, TOB $4 \mathrm{MO}$

\section{Appendix 2. Greenhouse Plans}

The Cornell 21 Plastic Greenhouse. Dept. of Vegetable Crops, Cornell University, Ithaca, NY, 14850

Dome Plan (822-350), Quonset Plan (822-360) and others. Extension Agricultural Engineering. Pennsylvania State University. University Park, PA, 16802

Home Plastic Greenhouse (Circular 892), Virginia Polytechnic Institute, Blacksburg, VA, 24060

Plastic Covered Greenhouse (Building Plan 73) Oregon State University, Corvallis, Or 97330

Slant-Leg Rigid Frame Plastic Greenhouse (Plan 139). Agricultural Engineering Department, Rutgers University, New Brunswick, NJ, 08903

Plans for the Construction of a Brace Greenhouse. Design 2 (small greenhouse) or A3 (large greenhouse). Brace Research Institute, Macdonald College, McGill University, Ste. Anne de Bellevue, Quebec, H9X 3M1

A Gothic Greenhouse. Publication 487, Extension Division, Cooperative Extension Service, Virginia Polytechnic Institute and State University, Blacksburg, Virginia, 24061

Hobby Greenhouses and Other Gardening Structures, Extension Agricultural Engineer, NRAES, Riley-Robb, Cornell University, Ithaca, NY, 14853. The following plans are available in this publication: 
Greenhouses Lean-to, Portable Plastic. A-frame, Barrel Vault, Slantleg, Fiberglass, Tri-penta.

Hotbeds and Cold Frames-Greenhouse, Hotbed and Propagating Frame, Mini-hotbed and Propagating Frame, Hotbed, Cold Frame

Growth Chambers Plant Chamber Roomette, Propagation Unit for Plants, Cornell Automated Plant Grower.

Miscellaneous Temperature Alarm, Potting Bench, Greenhouse Benches.

THE FOLLOWING PLANS CAN BE ORDERED FOR A SMALL

CHARGE FROM: PLAN SERVICE, AGRICULTURAL ENGINEERING DEPT., UNIVERSITY OF KENTUCKY, LEXINGTON, KENTUCKY, 40506

Hobby Greenhouse 771-8. (10'x16', Conventional wooden greenhouse with heating and ventilation details

Ky Speciality Field Greenhouse 771-3. (10'x any length, conventional wooden greenhouse with heating and ventilation details)

Quonset Field Greenhouse 771-4. (10'x any length, conduit greenhouse with heating and ventilation details)

Gothic Greenhouse 5946. (8'x12', wooden structure)

Unit Heater - Fan H.V. System 811-7. (Vented gas fired unit heaters and exhaust fans with motorized intake shutters)

Poly Tube - Fan H.V. System 811-8.

Ventilation Requirements for Greenhouses 811-5. (Chart for determining ventilation requirements for cooling various sizes and shapes of greenhouses)

\section{APPENDIX 3 Some Canadian Suppliers}

The following listing constitute neither an endorsement of these companies nor a suggestion that other companies do not supply similar products.

\section{Greenhouse Builders: Edmonton}

Alberta Sunrooms \& Patio Corners Parallel Builders

7909 Argyll Road - 468-5860

26 - 53310 Range Road, 211

Ardrossan

All-Alume Greenhouses, Alberta

14320 McKenzie Drive - 452-6252

Canadian Consumers Products

Edmonton - 461-1092

Hobby Green Ltd.

6909 - 104 Street - 435-7753

Imperial Greenhouses \& Solarium

16609 - 111 Avenue - 483-8780

Merlund Plastics Ltd.

100, 16815 - 117 Avenue

O.P.S. Greenhouse Builders

217, 53050 Range Road 211,

Ardrossan

Sky Tech. Design Inc.

16415 - 132 Avenue - 447-1319

Sun Dial Greenhouses

11150 - 156 Street - 452-5640

Supreme Windows

16935 - 110 Avenue - 483-3463

Solarium Shop Ltd.

15820 - 111 Avenue - 452-6621

Precision Plastics

7421 - 67 Street - 468-5366

Custom made for building

suppliers only.
20560, No. 10 Highway Bypass

Unit 109

LANGLEY, B.C. V3A 6 K8

3. Paul Boers Greenhouses

P.O. Box 134

ST. DAVIDS, Ontario LOS $1 \mathrm{PO}$

(416)-262-4911 or (416)-262-5122

Telex: 061-5344

4. Campbell - O'Brien Ltd

348 Guelph Street, Unit 5

GEORGETOWN, Ontario L7G 4B5

(416)-877-0129

5. IBG (Canada) Ltd.

P.O. Box 2000

BEAMSVILLE, Ontario LOR 1B0

(416)-563-8276

6. Westbrook Greenhouses Systems Ltd.

270 Hunter Road, P.O. Box 99

GRIMSBY, Ontario L3M 4G1

(416)-945-9611

Telex: 061-5291

7. Frank Jonkman and Sons Ltd

R.R. 4

BRADFORD, Ontario L3Z $2 A 6$

(416)-775-5353

Telex: 06-218310

Contact - Frank Jonkman

8. Prins Greenhouses Ltd.

38900 No. 4 Road, R.R. 4

ABBOTSFORD, B.C. V2S 4N4

(604)-852-4001 or (604)-852-4009

Telex: 04-363544

9. Harry Sharp and Son Ltd.

7028 MacPherson Avenue

BURNABY, B.C. V5J 4N3

(604)-430-1525

Toll Free: 112-800-663-9878

10. Jack Van Klaveren Ltd.

P.O. Box 910

ST. CATHARINES, Ontario L2R $6 Z 4$

Contact - Ross Richardson, Alberta

Nisku Business Park

Nisku, Alberta

(403)-955-7248

11. Ball Superior Ltd.

1155 Birchview

MISSISSAUGA, Ontario L5H 3E1

(416)-278-5201

Alberta Contact - Jim Gray-462-2358

12. W.R. Grace and Co. of Canada Ltd.

14810-123 Avenue

EDMONTON, Alberta T5L 2 Y5

(403)-454-4511

Contact-Bob Mieske

Material

Supplies

13. Harnois Industries Inc.
1. The Professional Gardener Co. Ltd.

915 - 23 Avenue, S.E.

CALGARY, Alberta T2G 1P1

(403)-263-4200

Telex: 03-821968

Toll Free: 1-800-661-1275
2. Vary Industries Ltd

Greenhouses

Equipment

Greenhouses

Greenhouses

Greenhouses

Greenhouses

Greenhouses

Greenhouses

Greenhouse

Material

Supplies

Greenhouse

Materials

Supplies

Greenhouse

Materials

Supplies

Media

Fertilizers

1044 Principale, C.P. 150

ST. THOMAS, Quebec JOK 3LO

(516)-756-1041
Greenhouse

Material

Supplies 
14. Lord and Burnham Co. Ltd.

68 Sackville Dr. Southwest

CALGARY, Alberta T2W OW2

(403)-255-3033

Contact-G. Bennett

15. All Canadian Boiler

Lorenz Ratke

14507-130 Avenue

EDMONTON, Alberta T5L 3M5

(403)-451-5005

\section{SEED SUPPLIERS}

1. De Ruiter Seeds Inc.

P.O. Box 20228

COLUMBUS, Ohio 43220

U.S.A.

(614)-459-1498

Telex: 757615 Deruiter U.D.

2. Bruinsma Seed Co.

P.O. Box 1463

HIGH RIVER, Alberta TOL 1B0

(403)-652-4768

Contact-Frank Jonkman

3. Nunhems Zaden BV

P.O. Box 4005

6080 AA Haelen, Holland

Phone: 04759-9241

4. Stokes Seeds Ltd.

P.O. Box 10, 39 James Street

ST. CATHARINES, Ontario L2R 6 R6

(416)-688-4300
Boilers

\section{BIOLOGICAL AGENTS}

1. Applied Bio-Nomics Ltd.

P.O. Box 2637

SIDNEY, B.C., V8L 4C1

(604)-656-5434

Contact-Don Elliott

Coal Heating

2. Better Yield Insects

P.O. Box 3451, Tecumseh Station

WINDSOR, Ontario N8N 3C4

(519)-727-6108

\section{ARTIFICIAL LIGHTS}

Greenhouses

Vegetable \&

Flower Seeds

Greenhouse

Vegetable \&

Flower Seeds

Greenhouse

Vegetable

Seeds

Vegetable,

Flower \&

Herb Seeds

1. GTE Sylvania Canada Ltd.

14335-121A Avenue

EDMONTON, Alberta T5L 2T1

2. P.L. Light Systems Canada Inc

P.O. Box 206

183 South Service Road

GRIMSBY, Ontario L3M 4G3

(416)-945-4133

Contact-Harry Moes

\section{GREENHOUSE COMPUTERS}

1. Priva Computers Inc. VINELAND STATION, Ontario

(416)-562-7351

$(416)-562-7351$

P.O. Box 110, South Service Road, Victoria Avenue

Biological

Control

Agents

Biological

Control

Agents

\section{APPENDIX 4. Ideas for Solar-Heated Greenhouses}

Rock-wall passive solar heating system Rock-wall active solar heating system Rock bed active solar heating system

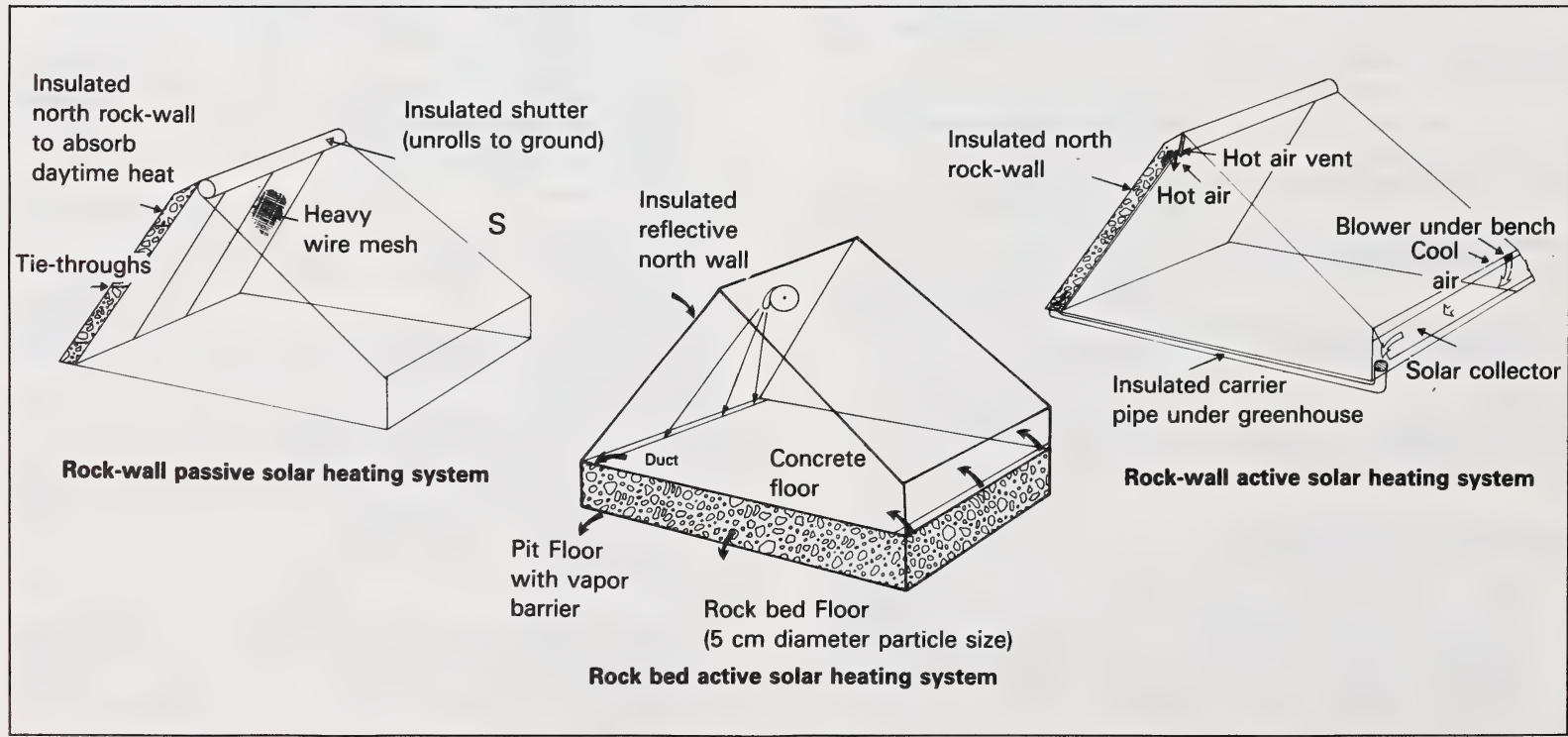




\begin{tabular}{|l|l|}
\hline \multicolumn{2}{|c|}{ Suggested Soil Mixes for Various Plants } \\
\hline PLANT & SUGGESTED MIX \\
\hline African violet & $1 / 3$ soil, $1 / 3$ peat, $1 / 3$ perlite or sand \\
Azaleas & peat \\
Bedding plants & $1 / 3$ soil, $1 / 3$ peat, $1 / 3$ perlite \\
Begonias & $1 / 2$ soil, $1 / 2$ peat \\
Bonsai & $1 / 3$ soil, $1 / 3$ sand, $1 / 3$ peat \\
Foliage Plants & $1 / 2$ peat, $1 / 4$ vermiculite, $1 / 4$ perlite \\
Gardenias & $1 / 2$ soil, $1 / 2$ acid peat $(\mathrm{pH} 4.5-5.0)$ \\
Cattleyas & $1 / 2$ perlite, $1 / 2$ firbark, osmunda or peat \\
Cymbidiums & $1 / 3$ fir bark, $1 / 3$ osmunda or redwood fiber, $1 / 3$ perlite \\
Seed germination & $1 / 2$ fine sand, $1 / 2$ peat \\
\hline
\end{tabular}

\begin{tabular}{|c|c|c|c|c|c|c|c|c|}
\hline \multicolumn{9}{|c|}{$\begin{array}{l}\text { University of California Soilless Mix } \\
\text { (to make } 1 \text { cubic metre) }\end{array}$} \\
\hline MIX & $\begin{array}{c}\text { POTASSIUM } \\
\text { NITRATE } \\
\mathbf{g}\end{array}$ & $\begin{array}{c}\text { SINGLE } \\
\text { SUPER- } \\
\text { PHOSPHATE } \\
\text { kg }\end{array}$ & $\begin{array}{c}\text { DOLOMITIC } \\
\text { LIME } \\
\text { kg }\end{array}$ & $\begin{array}{c}\text { CALCIUM } \\
\text { CARBONATE } \\
\text { LIME } \\
\mathbf{k g}\end{array}$ & $\begin{array}{c}\text { GYPSUM } \\
\text { kg }\end{array}$ & pH & $\begin{array}{l}\text { FINE } \\
\text { SAND } \\
\text { (cubic }\end{array}$ & $\begin{array}{c}\text { PEAT } \\
\text { MOSS } \\
\text { metre) }\end{array}$ \\
\hline $\begin{array}{l}\text { Rooting } \\
\text { cuttings }\end{array}$ & 300 & 1.5 & 0.9 & - & 1.5 & 7.0 & 1 & - \\
\hline $\begin{array}{l}\text { Bedding } \\
\text { plants }\end{array}$ & 220 & 1.5 & 2.7 & 0.7 & 0.7 & 6.8 & $3 / 4$ & $1 / 4$ \\
\hline $\begin{array}{l}\text { Potting } \\
\text { plants }\end{array}$ & 150 & 1.5 & 4.5 & 1.5 & - & 6.5 & $1 / 2$ & $1 / 2$ \\
\hline $\begin{array}{l}\text { Transplanting, } \\
\text { seed germination }\end{array}$ & 150 & 1.2 & 3.0 & 2.4 & - & 6.0 & $3 / 4$ & $1 / 4$ \\
\hline $\begin{array}{l}\text { Azaleas and other } \\
\text { acid loving plants }\end{array}$ & 20 & 0.6 & 1.5 & 3.0 & - & 5.7 & - & 1 \\
\hline
\end{tabular}

* To each mix also add $1.0 \mathrm{~kg}$ of blood meal or Hoof'n Horn and $115 \mathrm{~g}$ of potassium sulphate.

University of California Soilless Mix (to make 1 cubic metre)

\section{CORNELL MIXES}

The Cornell Peat-Lite Mix* is formulated for growing tropical plants. The Foliage Plant Mix** and the Epiphytic Mix** formulas are adapted specifically for their respective plant types and are modifications of the original peat-lite mix.

Cornell has used Osmocote 14-14-14 and Peters 14-7-7 fertilizers with the tropical plant mixes with good results. Other fertilizers are omitted with the exception of dolomitic limestone and 20 per cent superphospate which are added to adjust the $\mathrm{pH}$ and to maintain adequate phosphorus levels. A trace element mix is added to assure a balance of minor elements. Trace element mixes can be purchased from specialty gardening centres.

*"Cornell Tropical Plant Mixes" by Russell C. Mott

** L.H. Bailey Hortorium, Cornell University, Ithaca, New York

\section{CORNELL PEAT-LITE MIX}

Mix 0.5 cubic metre each of sphagnum peat moss and perlite or vermiculite. Add $6 \mathrm{~kg}$ dolomitic limestone, $2.4 \mathrm{~kg}$ ammonium nitrate, $1.5 \mathrm{~kg}$ superphosphate, and $0.3 \mathrm{~kg}$ potassium chloride (omit if using vermiculite).

\section{CORNELL FOLIAGE PLANT MIX}

The Cornell Foliage Plant Mix was developed for those plants that need a growing medium with high moisture-retention characteristics. Plants having a fine root system or possessing many fine root hairs are included in this group.

\section{MATERIAL}

Sphagnum peat moss

(screened 12" mesh)

Horticultural vermiculite (No. 2)

Perlite (medium grade)

Ground dolomitic limestone

Superphosphate 20 (powdered)

Fertilizer (10-10-10)

Iron Sulphate

Potassium nitrate (14-0-44)

Granular wetting agent

Trace element mix
1 CUBIC METRE

$0.5 \mathrm{~m}^{3}$

$0.25 \mathrm{~m}^{3}$

$0.25 \mathrm{~m}^{3}$

$4.9 \mathrm{~kg}$

$1.2 \mathrm{~kg}$

$1.6 \mathrm{~kg}$

$0.4 \mathrm{~kg}$

$0.6 \mathrm{~kg}$

$0.9 \mathrm{~kg}$

according to

label instructions 


\section{CORNELL EPIPHYTIC MIX}

The Cornell Epiphytic Mix was developed for plants that require good drainage, aeration and have the ability to withstand drying between waterings. Plants having coarse, tuberous, or rhizomatous roots are in this category.

\section{MATERIAL}

1 CUBIC METRE

Sphagnum peat moss (screened $2.5 \mathrm{~cm}$ mesh)

Douglas, red or white fir bark* (about $0.5 \mathrm{~cm}$ size)

Perlite (medium grade)

Ground dolomitic limestone

Superphosphate 20\% (powdered)

Fertilizer

Iron Sulphate

Potassium nitrate (14-0-44)

Granular wetting agent

Trace element mix

* Fir bark comes from Douglas fir, white or red fir, or redwood, ground and screened to a definite size. Finely ground bark (about $0.5 \mathrm{~cm}$ ) has a dry weight of about $200 \mathrm{~g}$ per L. Fresh bark has a $\mathrm{pH}$ of about 5.0. Upon weathering, it becomes slightly more alkaline. The bark contains some nutrients, but these will not meet the requirements of growing plants.

\section{APPENDIX 6. Hydroponic Nutrient Solution}

\section{Stock Solution}

1. Get four clean 1 litre bottles and mark them A, B, C, D

2. Add water and dissolve the following nutrients:

Jar A $101 \mathrm{~g}$ potassium nitrate in $1 \mathrm{~L}$ water

Jar B $\quad 236 \mathrm{~g}$ calcium nitrate in $1 \mathrm{~L}$ water

Jar C $\quad 115 \mathrm{~g}$ ammonium phosphate in $1 \mathrm{~L}$ water

Jar D $\quad 246 \mathrm{~g}$ magnesium sulphate in $1 \mathrm{~L}$ water

3. Store solutions in a cool, dark place.

\section{Final Solution}

1. To make $1 \mathrm{~L}$ of final solution, add the stock solutions to $1 \mathrm{~L}$ of water in the following amounts*:

From Jar A-6 mL

From Jar $\mathrm{B}-4 \mathrm{~mL}$

From Jar $\mathrm{C}-2 \mathrm{~mL}$

From Jar D-1 mL

2. Purchase a soluble trace element mix (usually contains sulphur, boron, copper, iron maganese, molybdenum and zinc) and dilute and add according to instructions.

3. The final solution is now ready for use.

* Multiply these ammounts by 4 to convert to fluid ounces of stock solution needed to make 25 gallons of final solution (2 level tablespoons equals 1 fluid ounce).

\section{APPENDIX 7.}

\section{Small Pipe Frame Greenhouse}

This plan shows the basic construction of a fibreglass or polyethylene-covered pipe frame greenhouse. The greenhouse may be made larger than shown, up to $3600 \mathrm{~mm}$ wide.

\section{Framework}

The basic framework is of $20 \mathrm{~mm}$ pipe bent into a semicircular arch and attached to a plank frame at the base. Though the pipe could be bent in a home-made jig, it is probably simpler to run it through a commercial pipe bender at a plumbing or machine shop. Each corner of the frame should be anchored to a ground stake.

Standard wood framing is used for the end walls. This includes a large end wall vent panel.

\section{Covering}

The strongest and most durable covering is $1.5-3.2 \mathrm{~mm}$ greenhouse grade, non-corrugated fibreglass. Corrugated fibreglass will not bend to this small a curvature. Two standard length $2400 \mathrm{~mm}(8 \mathrm{ft})$ panels are more than adequate to circle the frame. The remainder may be used to close in the lower vent panels or end wall on the south side, leaving the north side solid. Additional comfort can be obtained by insulating the north wall with rigid insulation. Fasten the fibreglass to the pipe frame with self-trapping metal screws. Rigid fibreglass end wall sheathing is cut to fit the curve of the side of the wall, and the resulting crack filled by butyl caulking compound or a foam rubber weatherstrip.

Greenhouse grade 6 mil polyethlene can be used as well.

\section{Ventilation}

Small greenhouses heat up and cool off rapidly. It is difficult to provide roof vent in a curved roof; therefore a large end wall vent panel is shown on the plan. Good ventilation under the benches can be provided by the side vent panels attached to horizontal wood frame members.

This leaflet provides basic framing details for either a standard stud frame greenhouse, or a rigid frame building. The latter combines wall and roof framing as a continuous rigid frame which is cheaper and easier to construct. The plan shows a building $3600 \mathrm{~mm}$ wide, maximum span for this light frame construction; most hobby-sized houses are smaller than this. Adjust your plan accordingly. Pressure treated wood is best for framing, otherwise use decay-resistant wood like cedar or redwood. Do not use Penta preservative because it is toxic to plants. Salt-based preservatives, the type used for wood basements, are excellent.

\section{Stud Frame Construction}

The drawing shows the framing technique for a typical stud and rafter greenhouse. Studs and rafters are shown as $38 \times 89 \mathrm{~mm} ; 38$ $\times 64 \mathrm{~mm}$ framing is also commonly used. Ridge board, ridge cap, rafter and stud details are shown on the plan. Three options are shown for the lower rafter support. The steel angle with rafter support brackets is the most rugged; however, the wood frame is satisfactory. Rafters should have a drip groove, as show, to drain off condensation. Plates and sills should also be bevelled for drainage. If glass is to be installed, rafters and studs must be spaced to precisely accommodate cut glass panes, allowing for the notch in 

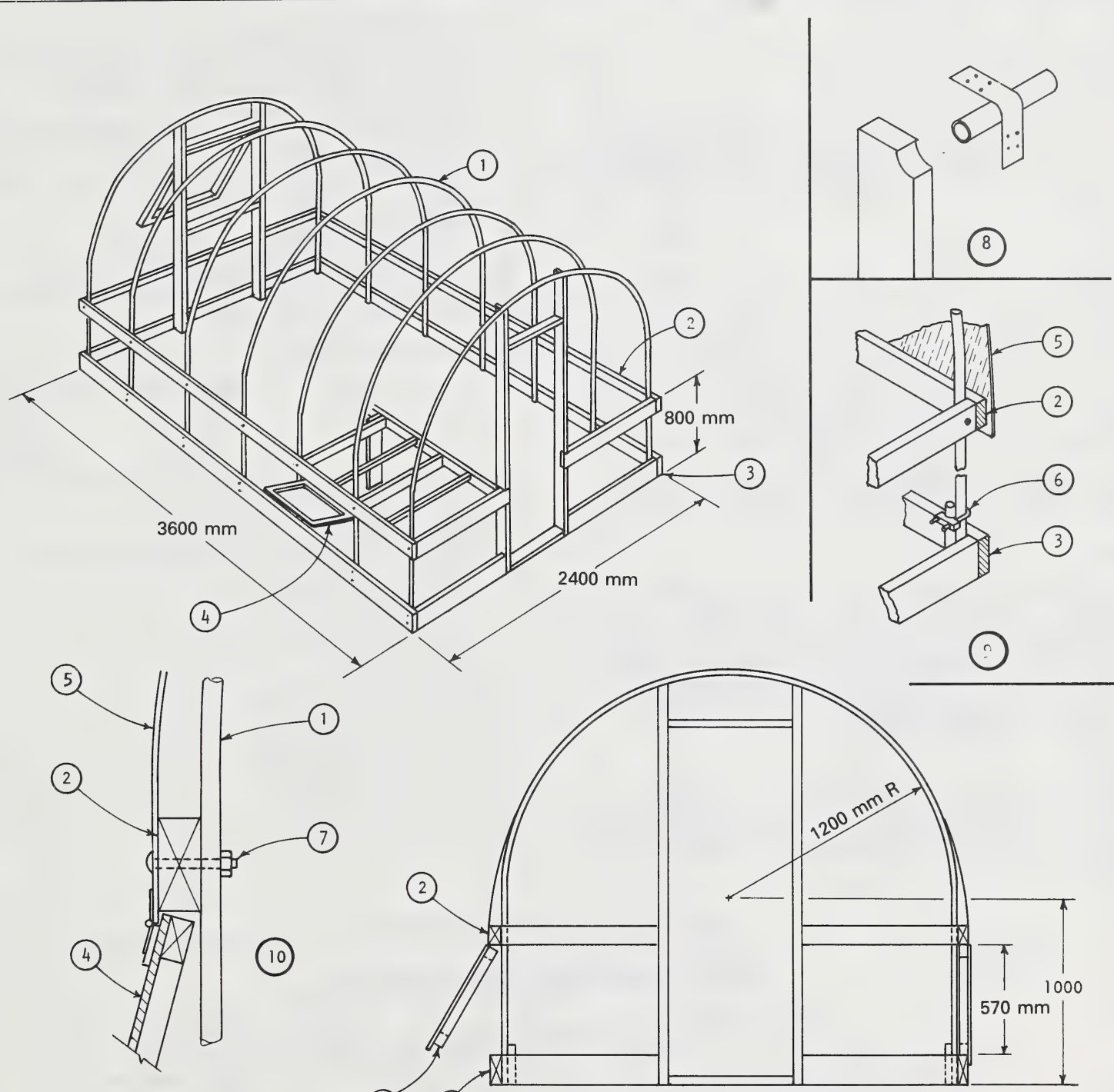

(4) (3)

1. $20 \mathrm{~mm}$ pipe frame; each frame $5770 \mathrm{~mm}$ long

2. $38 \times 89 \mathrm{~mm}$ frame bolt to pipe

3. $38 \times 140 \mathrm{~mm}$ base frame, preferably pressure-treated

4. Side vent, best made as one continuous vent panel

5. $1.5 \mathrm{~mm}-3.2 \mathrm{~mm}$ fibreglass covering
6. Anchor frame to a ground stake with $20 \mathrm{~mm}$ pipe clamp

7. $8 \mathrm{~mm}$ chrome steel carriage bolt

8. Stud-to-frame connection detail

9. Corner detail

10. Side vent detail 
the rafters and room for fitting glass panes. Check available glass size (usually 400 or $500 \mathrm{~mm}$ ) before construction. Rigid fibreglass is laid over rafters spaced $600 \mathrm{~mm}$

* Maximum size for small greenhouse
Dimensions reduced as required,
$2400 \times 3600 \mathrm{~mm}$ is most common size

End wall framing is of standard stud construction. When framing the door consider making the frame opening $1200 \mathrm{~mm}$ wide for easy access with equipment and materials. Close with either one wide door or a standard door together with a hinged side panel to allow full opening.

\section{Rigid Frame Construction}

A rigid frame can be adapted to glass panes, rigid fibreglass or polyethylene film coverings. With this construction technique, plywood gussets are used to combine wall and roof members into one integral frame. The rigid frames are fabricated on the ground then tipped into place on the foundation, and braced by the ridge board and eave stiffeners. The pertinent details are shown on the plan. As noted previously for wood frame construction, tailor the rafter shape and spacing to either glass or fibreglass covering.

Gusset plates are cut from $9 \mathrm{~mm}$ exterior grade plywood, and nailed into place with $64 \mathrm{~mm}$ concrete nails, half from each side of the joint. End wall and door framing are standard stud construction.

\section{Glazing}

The plan shows a detailed picture of sheet glass installation. Cut glass panes are laid in $12 \mathrm{~mm}$ channels rabbeted into the rafters, starting at the bottom and working shingle-fashion up the roof. First lay a bead of butyl caulking, a rolled tape of special glazing sealant which is much better than putty. Panes may then be held in place by glazing nails, or preferably by commercial rafter caps which do the neatest job of finishing the roof.

\section{Ventilation}

The plan shows vent panels along both sides of the ridge and along the side walls to provide maximum summer ventilation. Vent panels are made from $38 \mathrm{~mm}$ materials and should be framed to suit the glazing material used.

\section{Small Wood Frame Greenhouse}

1. $38 \times 89 \mathrm{~mm}$ framing

2. $9 \mathrm{~mm}$ plywood gusset plates

3. $38 \times 89 \mathrm{~mm}$ studs $400-600 \mathrm{~mm}$ oc (to match glass panel size)

4. $38 \times 89 \mathrm{~mm}$ ridge cap with drip groove each side

5. $38 \times 140 \mathrm{~mm}$ ridge board

6. Rabbet rafter and stud $10 \mathrm{~mm}$; offset gussets accordingly, if glass covering is used

7. Roof vents. Frame either to match glass panes or fibreglass covering

8. Detail for glass frame

9. Plywood cutting detail for haunch gussets

10. $64 \mathrm{~mm}$ concrete nails as shown; half from each side

11. $38 \times 140 \mathrm{~mm}$ horizontal brace with drip groove. Bevel top for glass

12. $38 \mathrm{~mm}$ stiffener with drip groove

\section{Glass Installation in Detail}

1. $38 \times 89 \mathrm{~mm}$ rafter Length as per chart

Bldg. width
$2400 \mathrm{~mm}$
$3000 \mathrm{~mm}$
$3600 \mathrm{~mm}$

\section{Rafter length $1440 \mathrm{~mm}$ $1800 \mathrm{~mm}$ $2160 \mathrm{~mm}$}

2. Ridge member $38 \times 140 \mathrm{~mm}$ for building up to $3600 \mathrm{~mm}$ long (38 $\times 184 \mathrm{~mm}$ for $4800 \mathrm{~mm}$ long)

3. $38 \times 89 \mathrm{~mm}$ ridge cap c/w drip grooves

4. Roof vents (both sides) frame to match glass panes or fibreglass covering

5. Glass installation detail

6. Drip groove (rafter only)

7. Rabbet $12 \mathrm{~mm}$ notch for glass

8. Butyl caulking strip

9. Commercial rafter cap

10. Stud or rafter member

11. Corner stud detail

12. Alternate eave framing

13. $75 \times 75 \times 4 \mathrm{~mm}$ angle iron

14. Rafter hanger, bolt to 13

15. $38 \times 89 \mathrm{~mm}$ wall stud

16. $38 \times 89 \mathrm{~mm}$ eave plate

\section{SMALL WOOD FRAME GREENHOUSE}

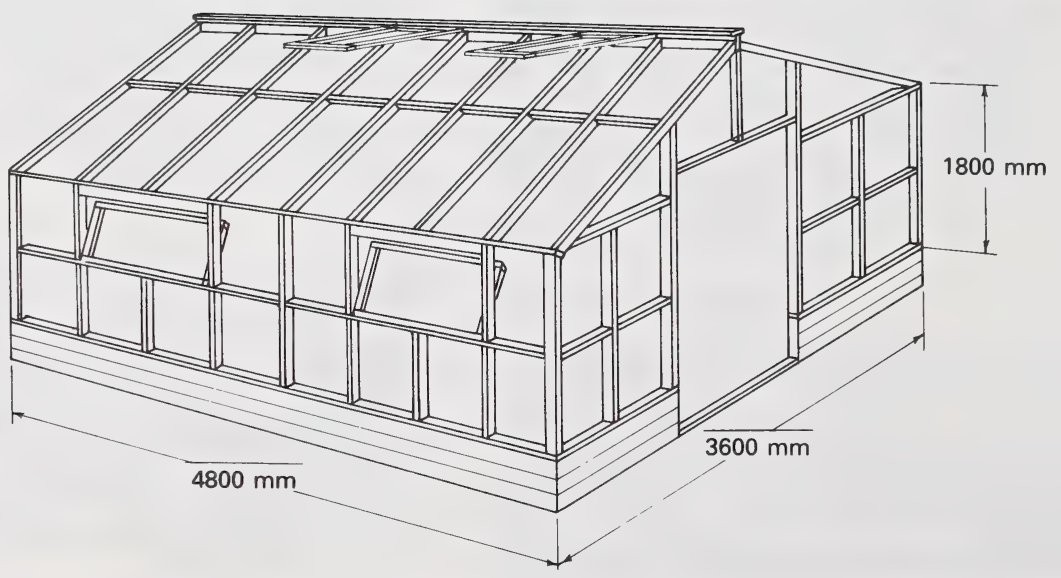

NOTE: - Illustrated is glass illustration detail, fibreglass uses the same frame without glass grooves. 

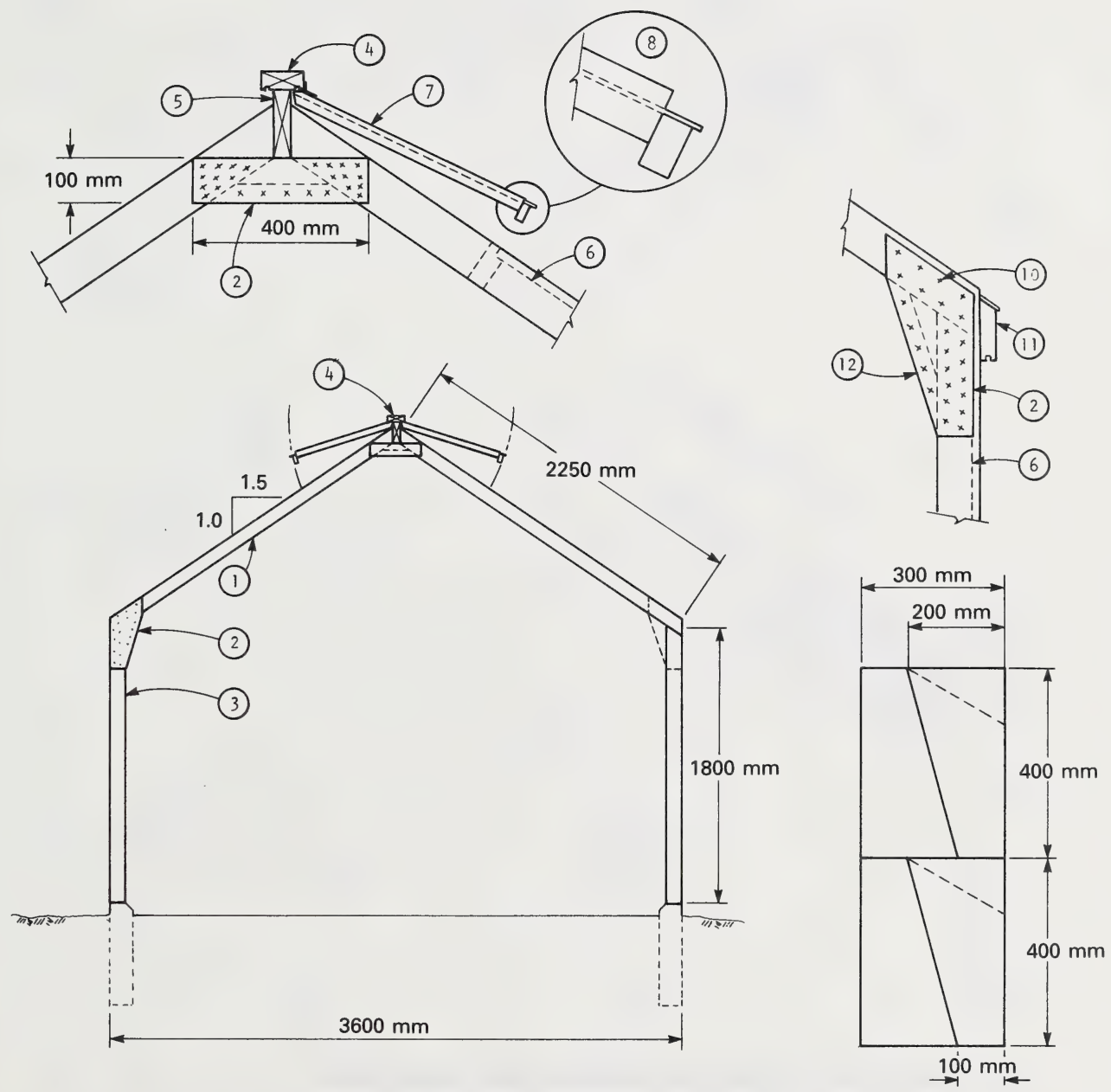

(9)

1. $38 \times 89 \mathrm{~mm}$ framing

2. $9 \mathrm{~mm}$ plywood gusset plates

3. $38 \times 89 \mathrm{~mm}$ studs $400-600 \mathrm{~mm}$ oc (to match glass panel size)

4. $38 \times 89 \mathrm{~mm}$ ridge cap with drip groove each side

5. $38 \times 140 \mathrm{~mm}$ ridge board

6. Rabbet rafter and stud $10 \mathrm{~mm}$; offset gussets accordingly, if glass covering is used
7. Roof vents. Frame either to match glass panes or fibreglass covering

8. Detail for glass frame

9. Plywood cutting detail for haunch gussets

10. $64 \mathrm{~mm}$ concrete nails as shown; half from each side

11. $38 \times 140 \mathrm{~mm}$ horizontal brace with drip groove. Bevel top for glass

12. $38 \mathrm{~mm}$ stiffener with drip groove 

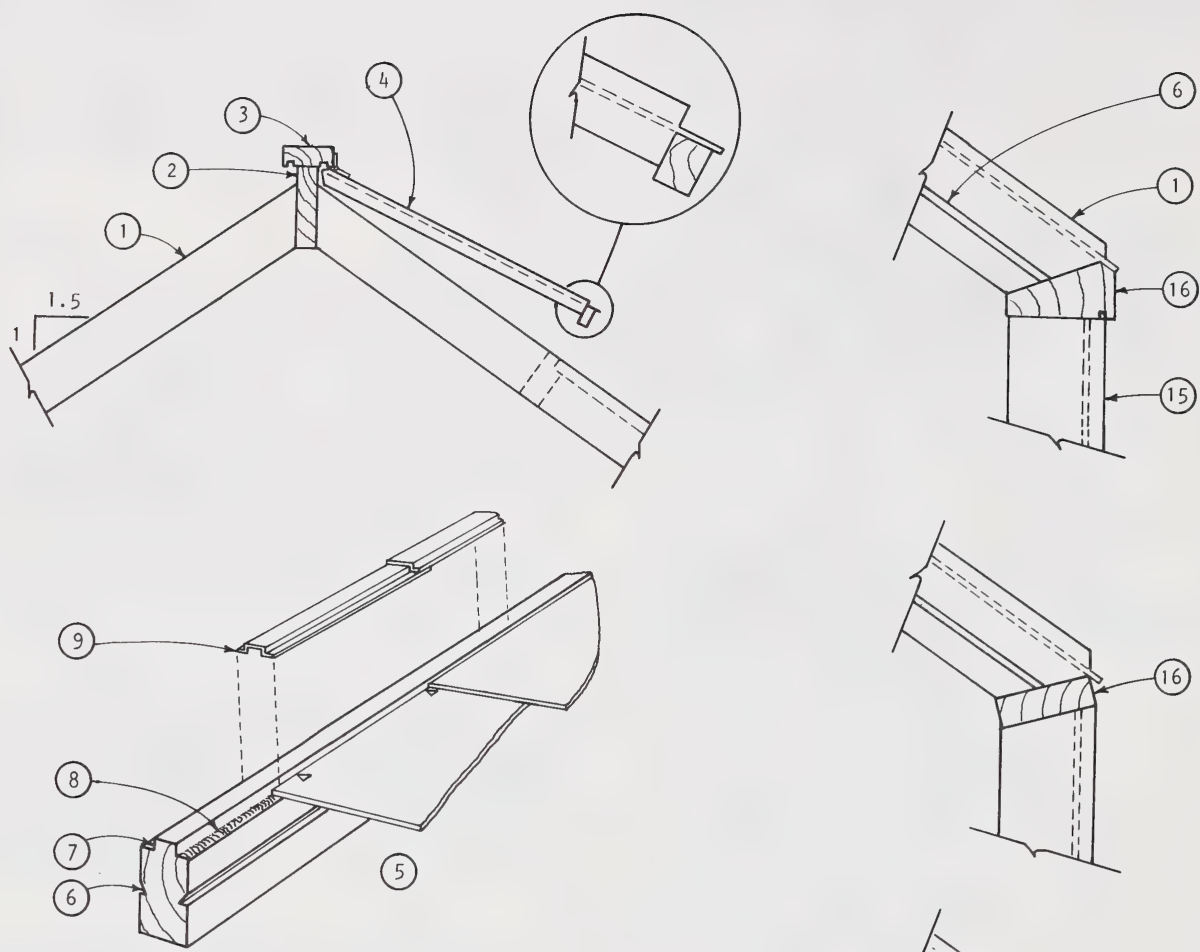

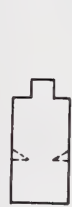

(10)

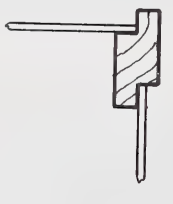

(11)

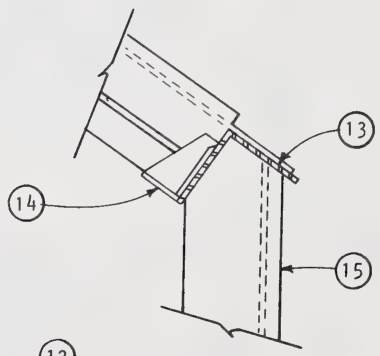

(12)

Note: - This is a metric drawing, all dimensions shown are millimetres.

- Illustrated is glass installation detail; fibreglass uses the same frame without glass grooves.

$\begin{array}{lcc}\text { 1. } 38 \times 89 \mathrm{~mm} \text { rafter } & \text { Bldg. width } & \text { Rafter length } \\ \text { Length as per chart } & 2400 \mathrm{~mm} & 1440 \mathrm{~mm} \\ & 3000 \mathrm{~mm} & 1800 \mathrm{~mm} \\ & 3600 \mathrm{~mm} & 2160 \mathrm{~mm}\end{array}$

2. Ridge member $38 \times 140$ for building up to $3600 \mathrm{~mm}$ long ( $38 \times 184$ for 4800 long)

3. $38 \times 89 \mathrm{~mm}$ ridge cap $\mathrm{c} w$ drip grooves

4. Roof vents (both sides) frame to match glass panes or fibreglass covering

5. Glass installation detail

6. Drip groove (rafter only)
7. Rabbet $12 \mathrm{~mm}$ notch for glass

8. Butyl caulkıng strip

9. Commercial rafter cap

10. Stud or rafter member

11. Corner stud detail

12. Alternate eave framing

13. $75 \times 75 \times 4 \mathrm{~mm}$ angle iron

14. Rafter hanger, bolt to 13

15. $38 \times 89 \mathrm{~mm}$ wall stud

16. $38 \times 89 \mathrm{~mm}$ eave plate 


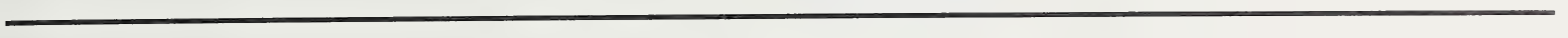






\begin{tabular}{|c|c|c|}
\hline To Convert & Into & Multiply by \\
\hline $\begin{array}{l}\text { Linear } \\
\text { millimetres }(\mathrm{mm}) \\
\text { centimetres }(\mathrm{cm}) \\
\text { metres }(\mathrm{m}) \\
\text { metres }(\mathrm{m})\end{array}$ & $\begin{array}{l}\text { inches } \\
\text { inches } \\
\text { feet } \\
\text { yards }\end{array}$ & $\begin{array}{l}0.039 \\
0.394 \\
3.28 \\
1.09\end{array}$ \\
\hline $\begin{array}{l}\text { Weight } \\
\text { grams (g) } \\
\text { grams (g) } \\
\text { kilograms (kg) }\end{array}$ & $\begin{array}{l}\text { ounces (avpd.) } \\
\text { pounds } \\
\text { pounds }\end{array}$ & $\begin{array}{l}0.035 \\
0.002 \\
2.205\end{array}$ \\
\hline $\begin{array}{l}\text { Area } \\
\text { square centimetres }(\mathrm{cm})^{2} \\
\text { square centimetres }(\mathrm{cm})^{2} \\
\text { square metres }(\mathrm{m})^{2} \\
\text { square metres }(\mathrm{m})^{2} \\
\text { square metres }(\mathrm{m})^{2} \\
\text { hectares }\end{array}$ & $\begin{array}{l}\text { square feet } \\
\text { square inches } \\
\text { square feet } \\
\text { square yards } \\
\text { acres } \\
\text { acres }\end{array}$ & $\begin{array}{l}0.001 \\
0.155 \\
10.76 \\
1.20 \\
.00025 \\
2.5\end{array}$ \\
\hline $\begin{array}{l}\text { Temperature } \\
\text { degrees Celsius }\end{array}$ & $\begin{array}{l}\text { degrees } \\
\text { Fahrenheit }\end{array}$ & $\left({ }^{\circ} \mathrm{C} \times 9 / 5\right)+32$ \\
\hline $\begin{array}{l}\text { Volume } \\
\text { litres (L) } \\
\text { litres (L) } \\
\text { millilitre (ml) }\end{array}$ & $\begin{array}{l}\text { gallons } \\
\text { ounces (fluid) } \\
\text { ounces (fluid) }\end{array}$ & $\begin{array}{l}0.220 \\
35.195 \\
0.0035\end{array}$ \\
\hline $\begin{array}{l}\text { Miscellaneous } \\
\mathrm{kg} / \mathrm{m}\end{array}$ & $\mathrm{lb} / \mathrm{ft}$ & .20 \\
\hline
\end{tabular}




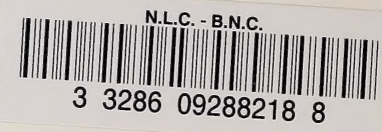

